\title{
Aggregation versus biological activity in gold(I) complexes. An unexplored concept.
}

Andrea Pinto, ${ }^{\text {a,b. } ¥}$ Catarina Roma-Rodrigues, ${ }^{\mathrm{c}, \mathrm{d}, ¥}$ Jas S. Ward, ${ }^{\mathrm{e}}$ Rakesh Puttreddy, ${ }^{\mathrm{f}}$ Kari

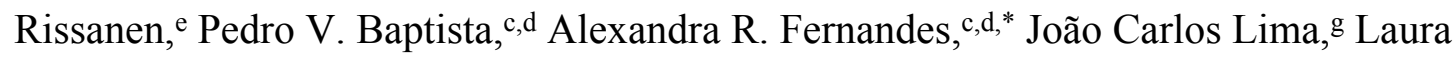
Rodríguez ${ }^{\mathrm{a}, \mathrm{b}^{*}}$

a Departament de Química Inorgànica i Orgànica, Secció de Química Inorgànica, Universitat de Barcelona, Martí i Franquès 1-11, E-08028 Barcelona, Spain

${ }^{b}$ Institut de Nanociència i Nanotecnologia (IN²UB). Universitat de Barcelona, 08028 Barcelona,Spain.e-mail: laura.rodriguez@qi.ub.es

${ }^{c}$ UCIBIO - Applied Molecular Biosciences Unit, Department of Life Sciences, NOVA

School of Science and Technology, NOVA University Lisbon, 2819-516 Caparica, Portugal

${ }^{d}$ Associate Laboratory i4HB - Institute for Health and Bioeconomy, NOVA School of Science and Technology, NOVA University Lisbon, 2819-516 Caparica, Portugal

e University of Jyvaskyla, Department of Chemistry, P.O. Box 35, 40014 Jväskylä, Finland

${ }^{f}$ Faculty of Engineering and Natural Sciences, Tampere University, P. O. Box 541, Tampere, FI-33101, Finland

${ }^{g}$ LAQV-REQUIMTE, Departamento de Química, CQFB, Universidade Nova de Lisboa, Monte de Caparica,Portugal.e-mail:ma.fernandes@fct.unl.pt

¥ equal contribution

\section{Supporting information}




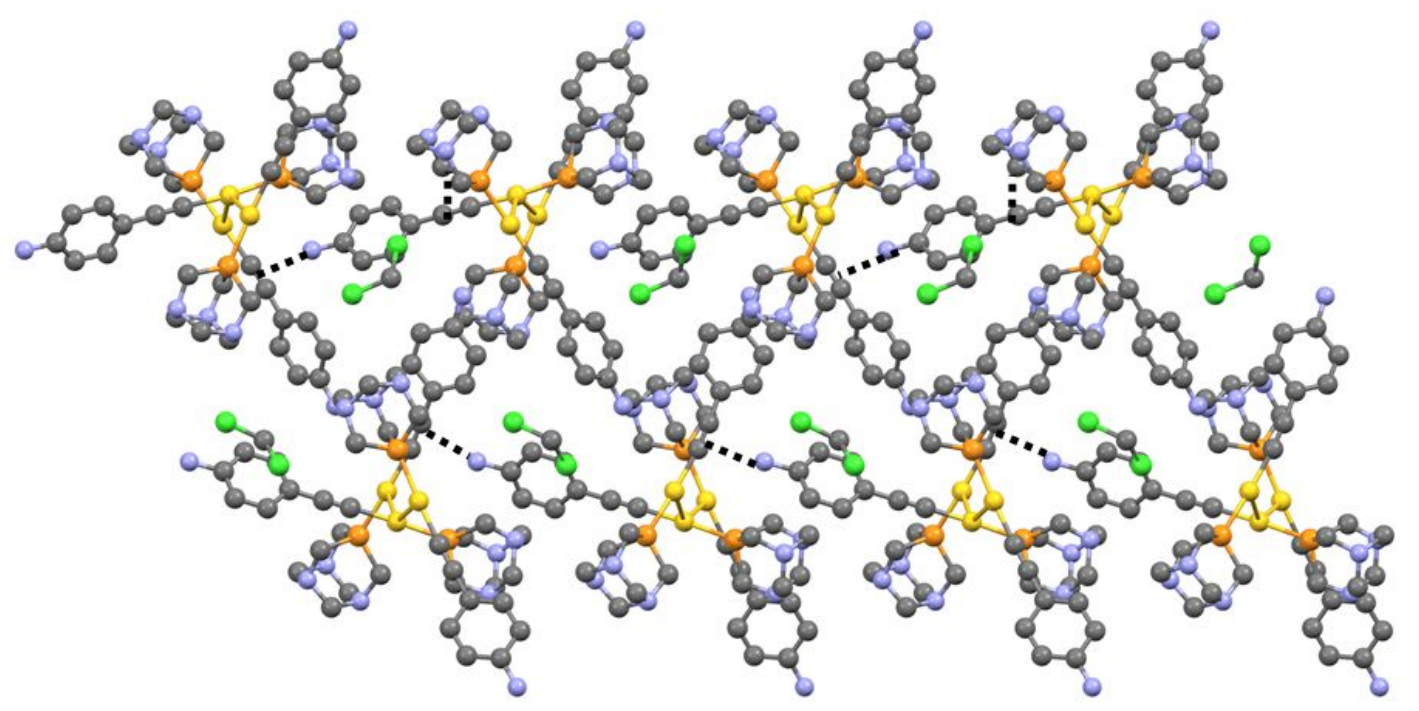

Figure S1. Representation of the packing of 1a.

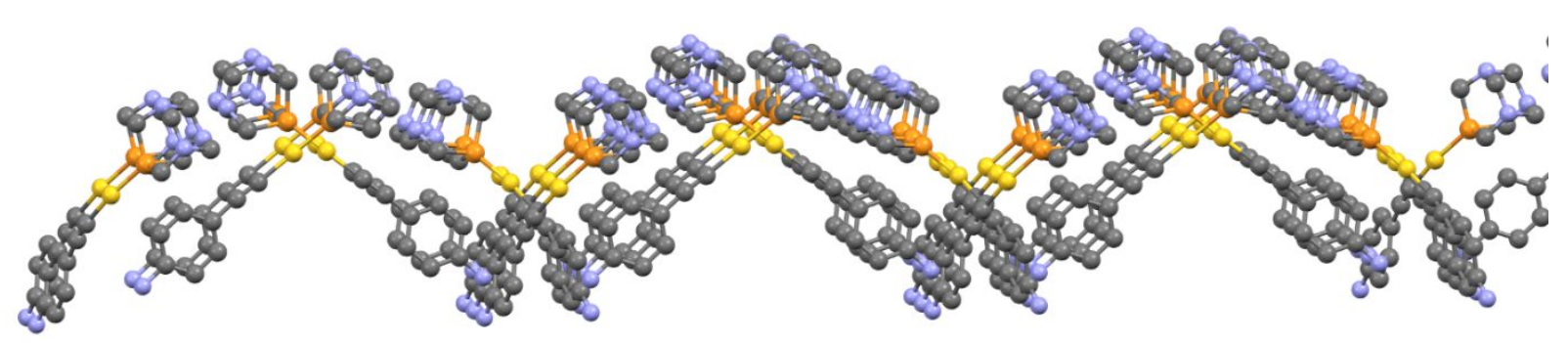

Figure S2. Representation of the packing of $\mathbf{1 b}$.

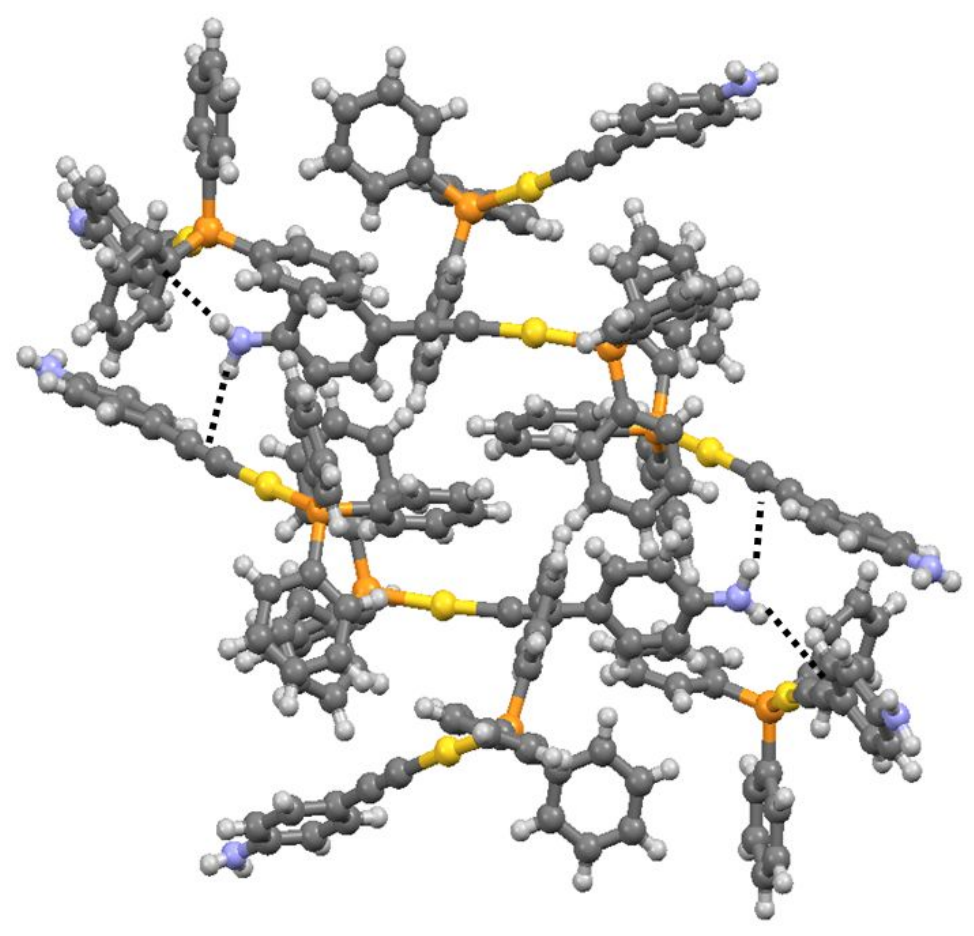


Figure S3. Representation of the packing of 4 .

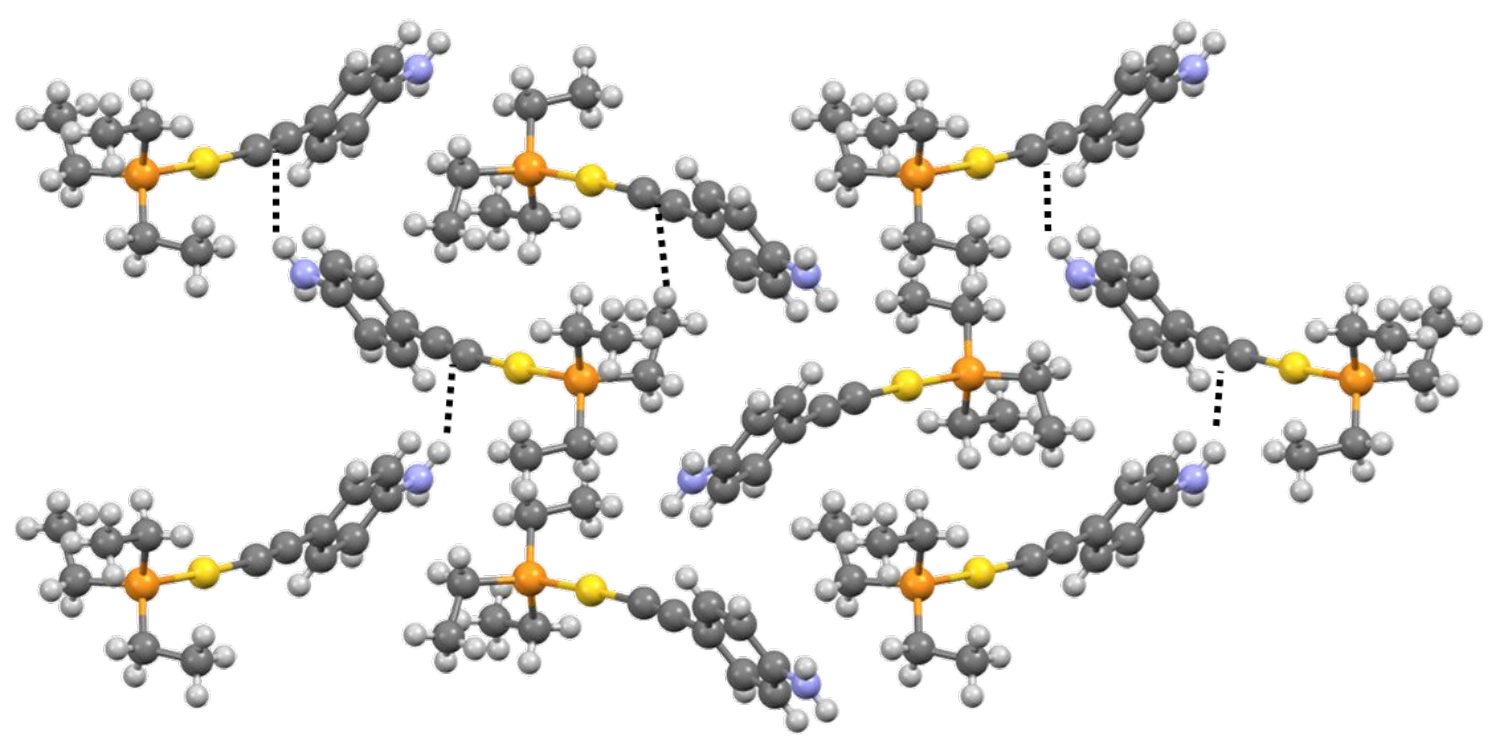

Figure S4. Representation of the packing of 5. 


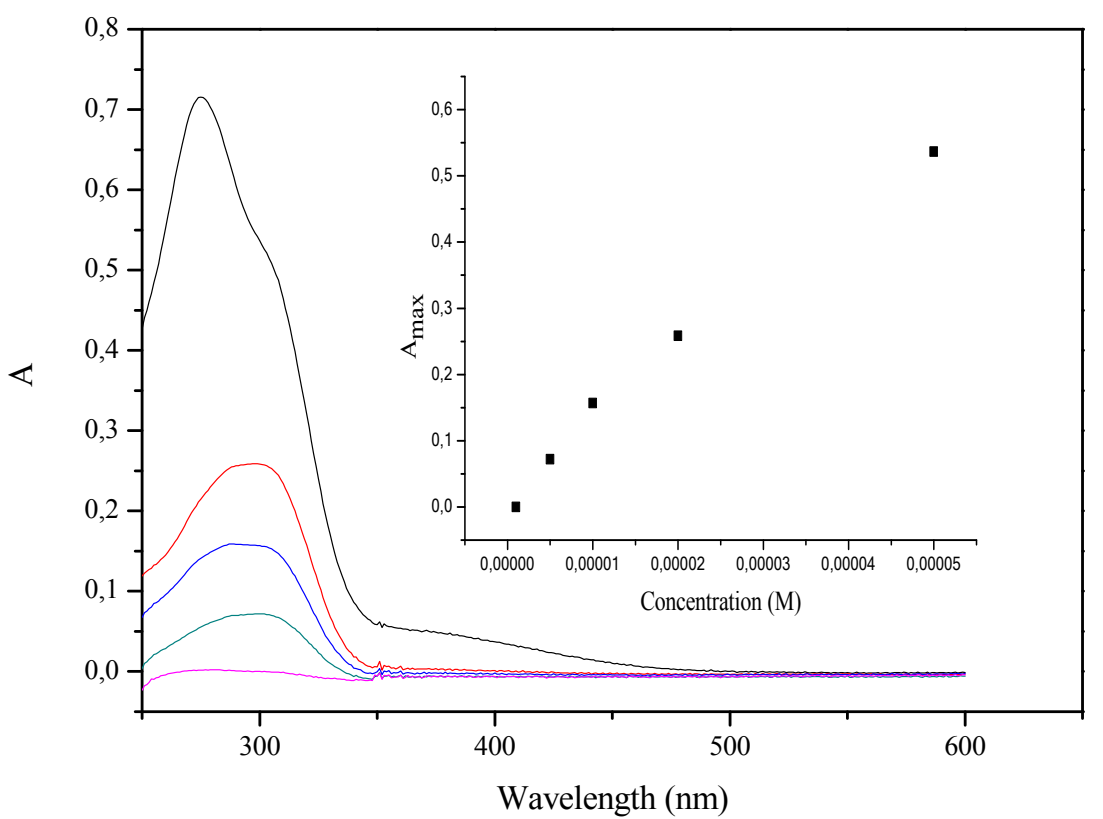

Figure S5. Absorption spectra of $\mathbf{1}$ at different concentrations.

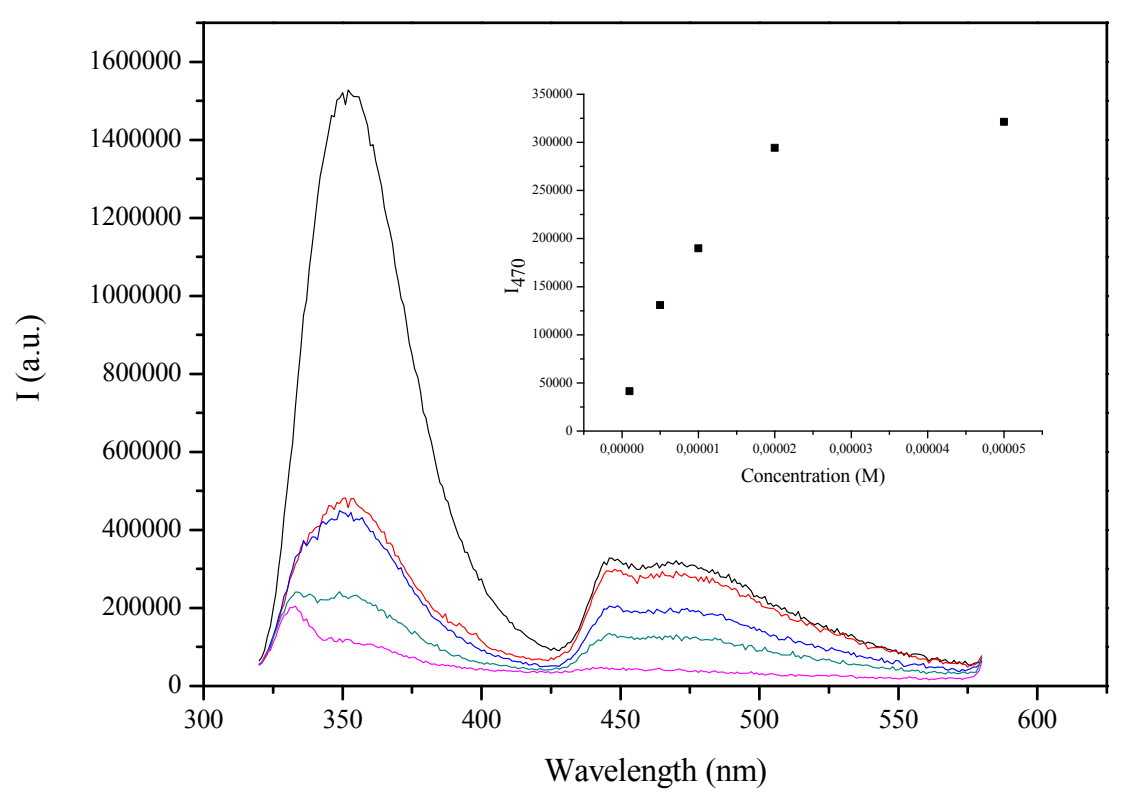

Figure S6. Emission spectra of $\mathbf{1}$ at different concentrations. 


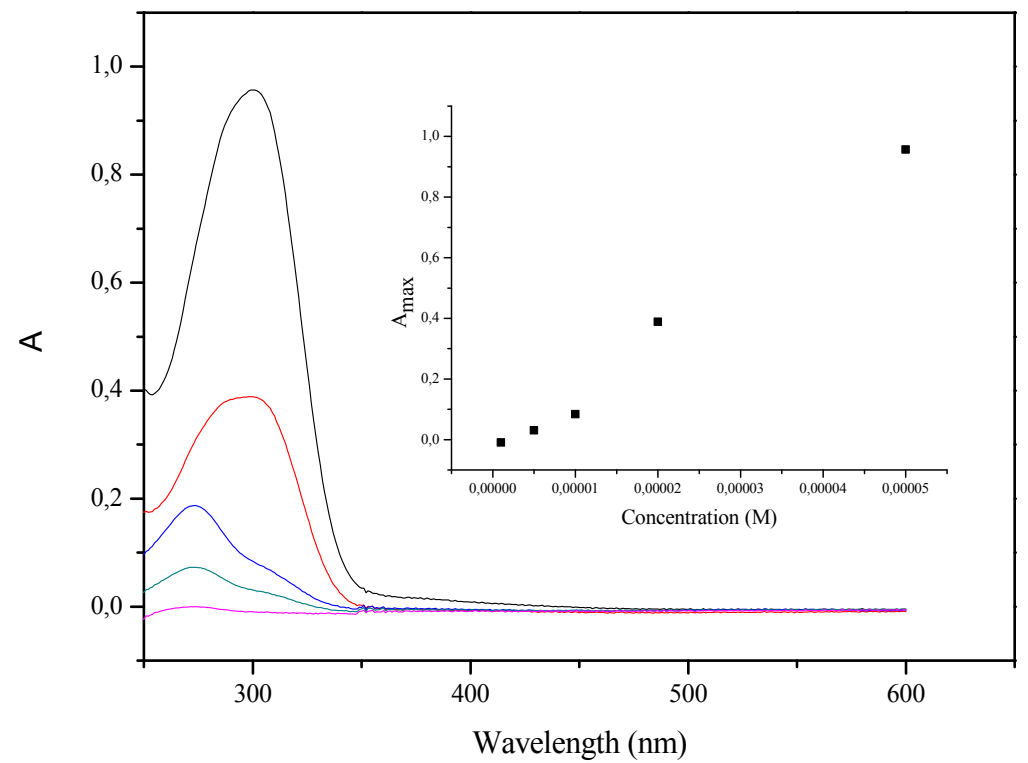

Figure S7. Absorption spectra of $\mathbf{2}$ at different concentrations.

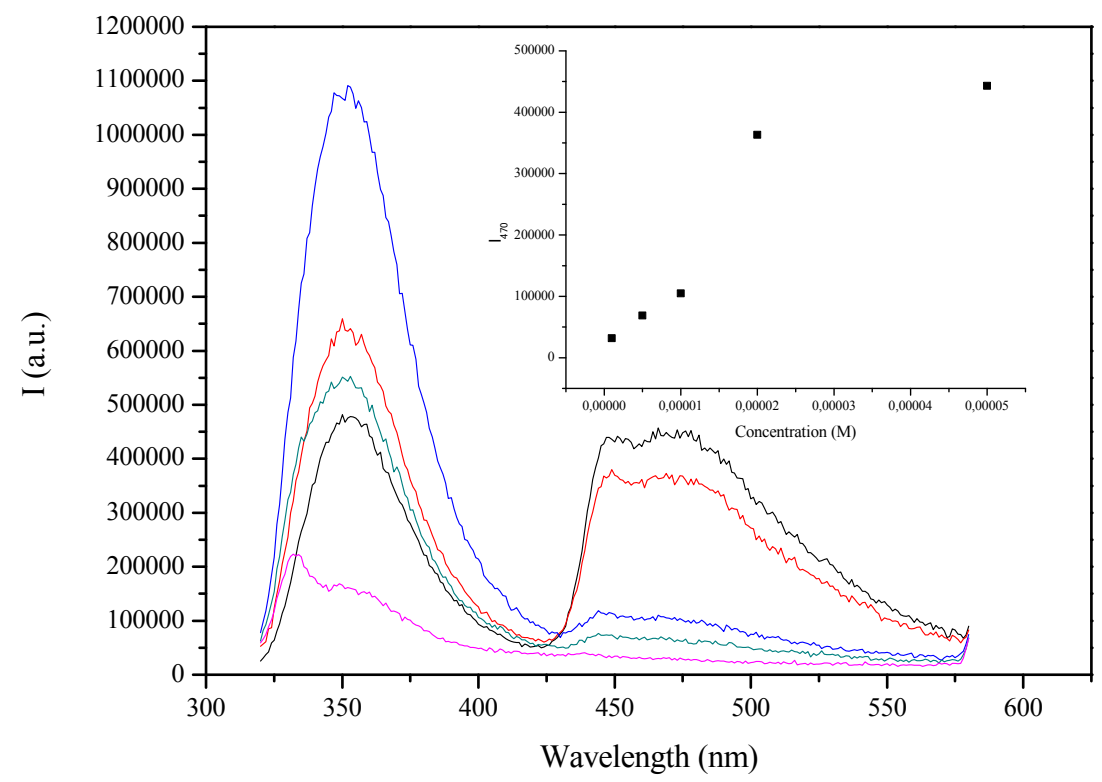

Figure S8. Emission spectra of $\mathbf{2}$ at different concentrations. 


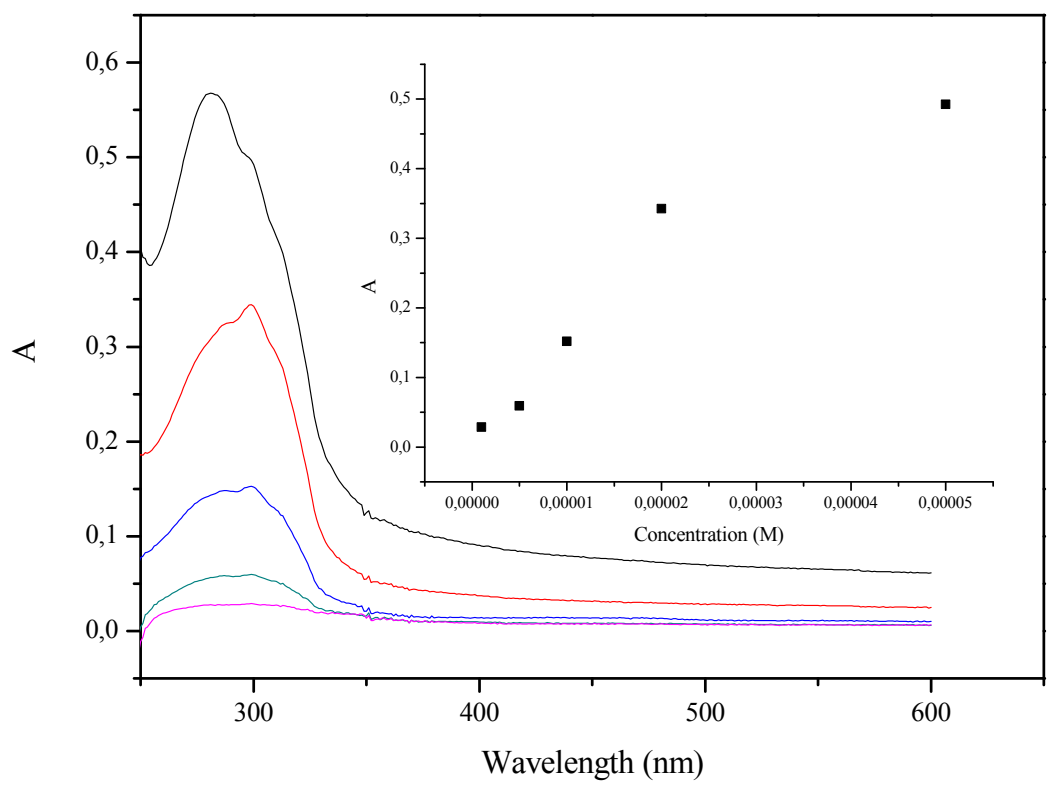

Figure S9. Absorption spectra of $\mathbf{3}$ at different concentrations.

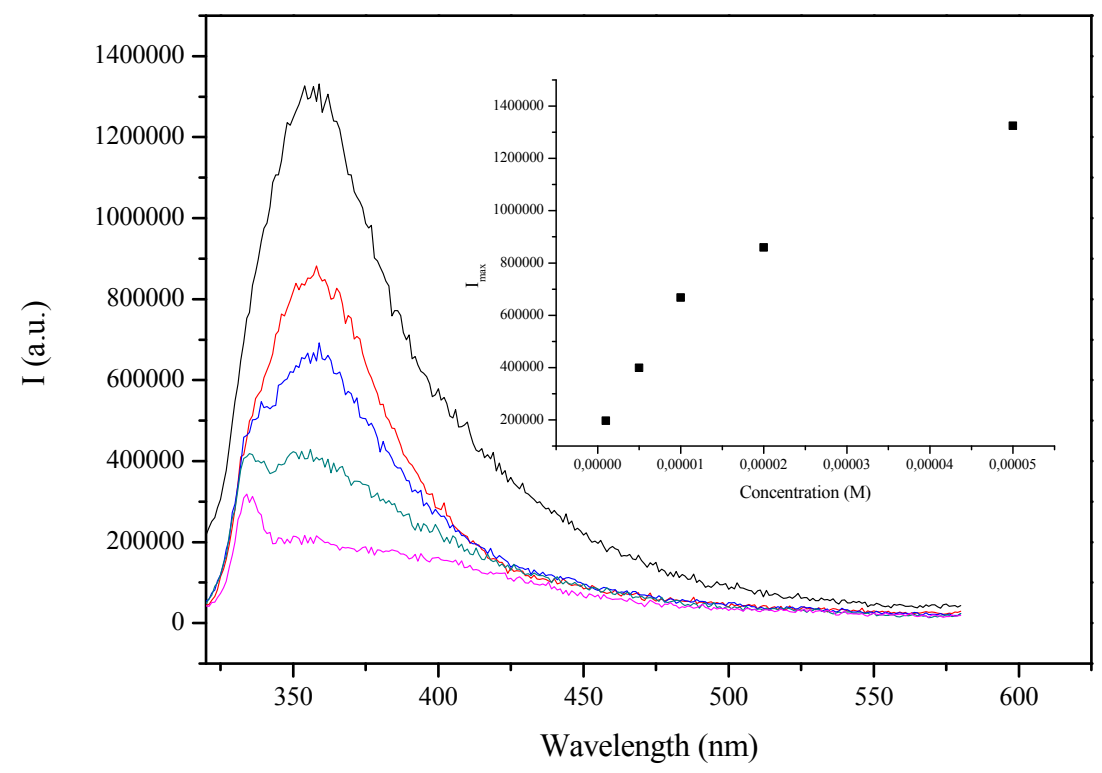

Figure S10. Emission spectra of $\mathbf{3}$ at different concentrations. 


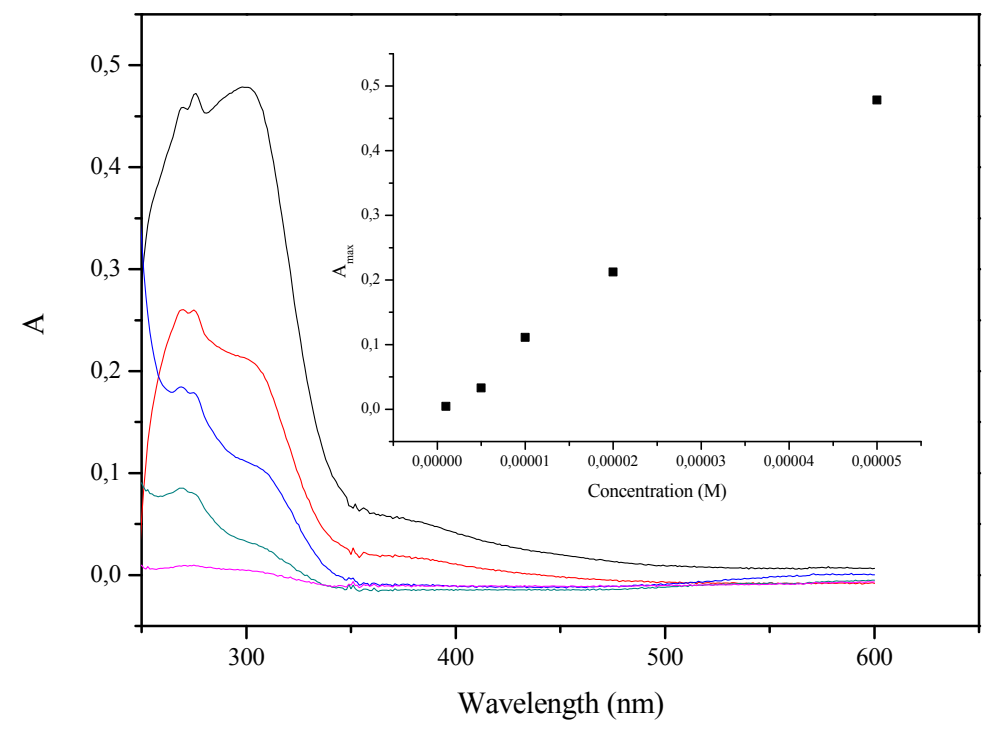

Figure S11. Absorption spectra of 4 at different concentrations.

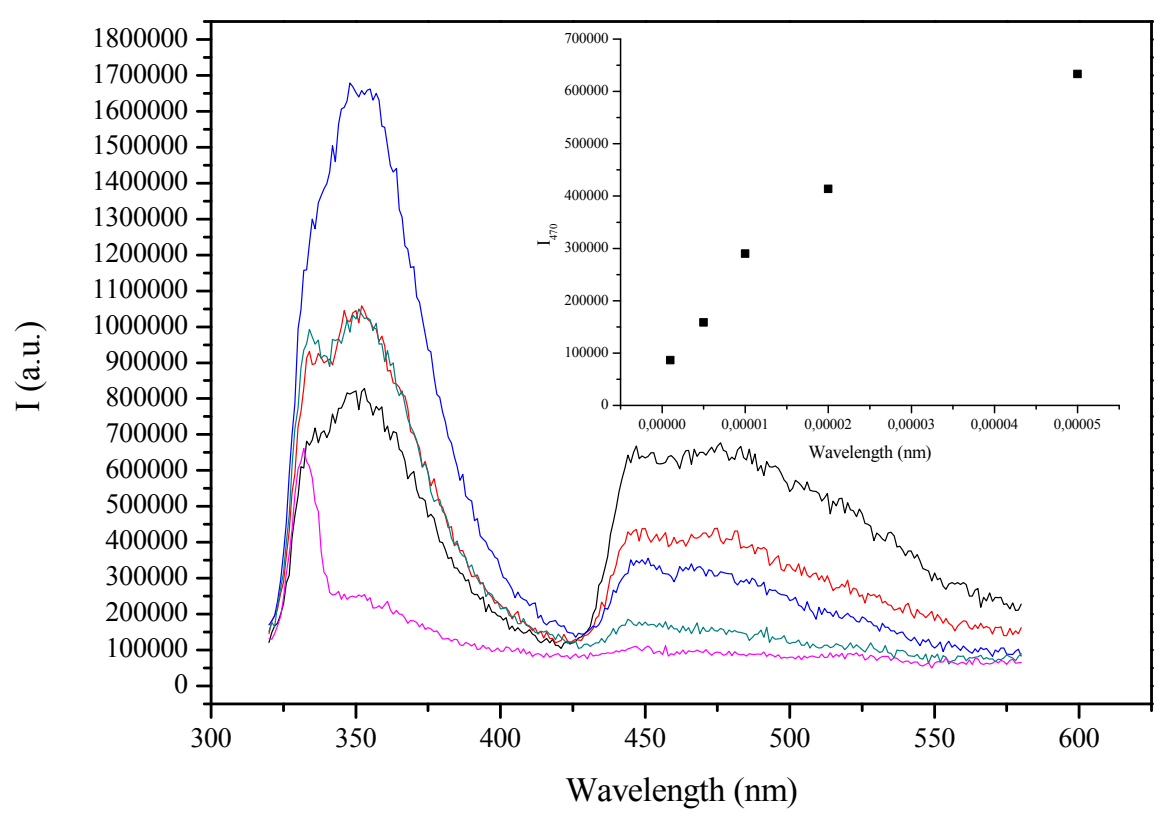

Figure S12. Emission spectra of $\mathbf{4}$ at different concentrations. 


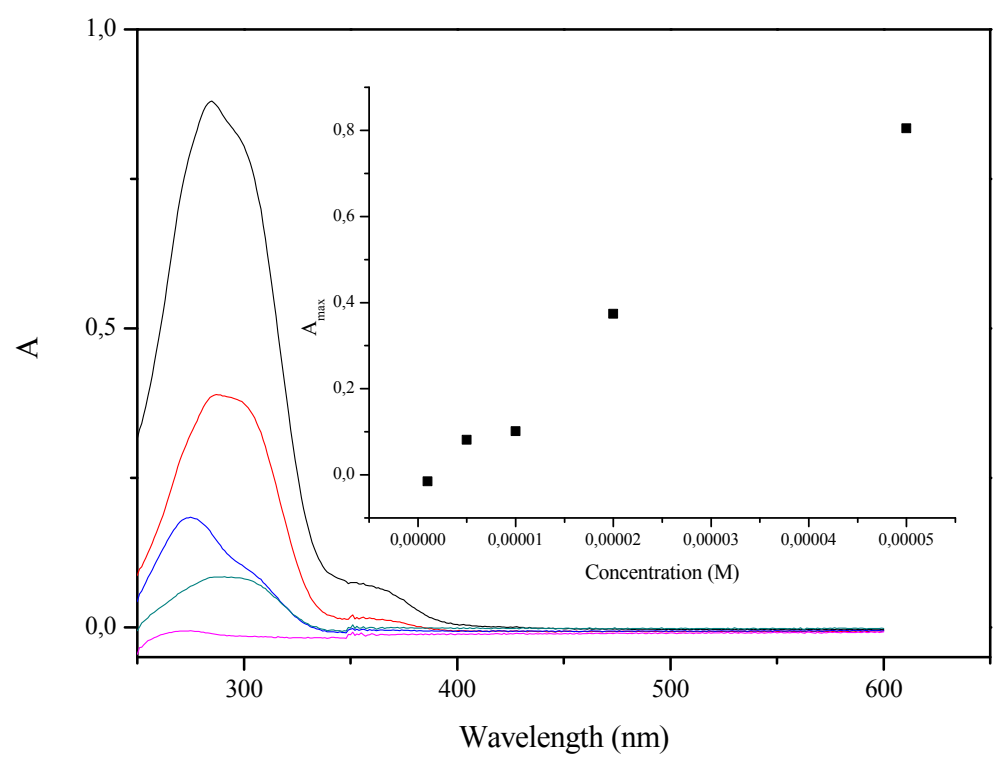

Figure S13. Absorption spectra of 5 at different concentrations.

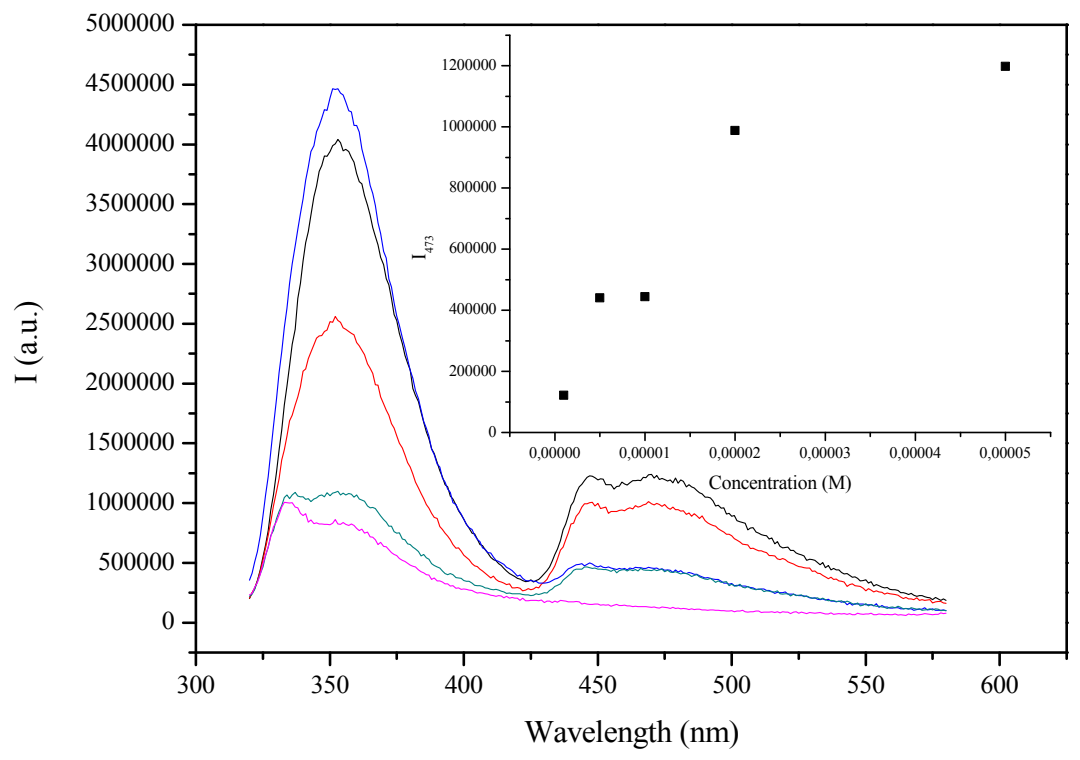

Figure S14. Emission spectra of 5 at different concentrations. 


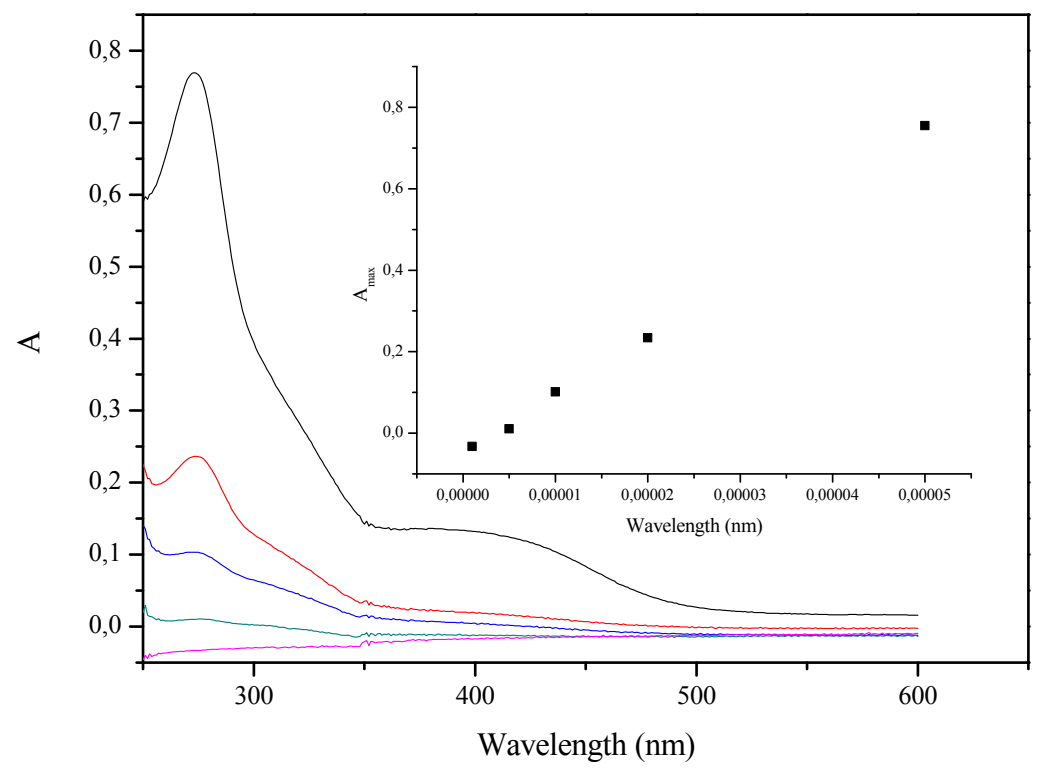

Figure S15. Absorption spectra of 6 at different concentrations.

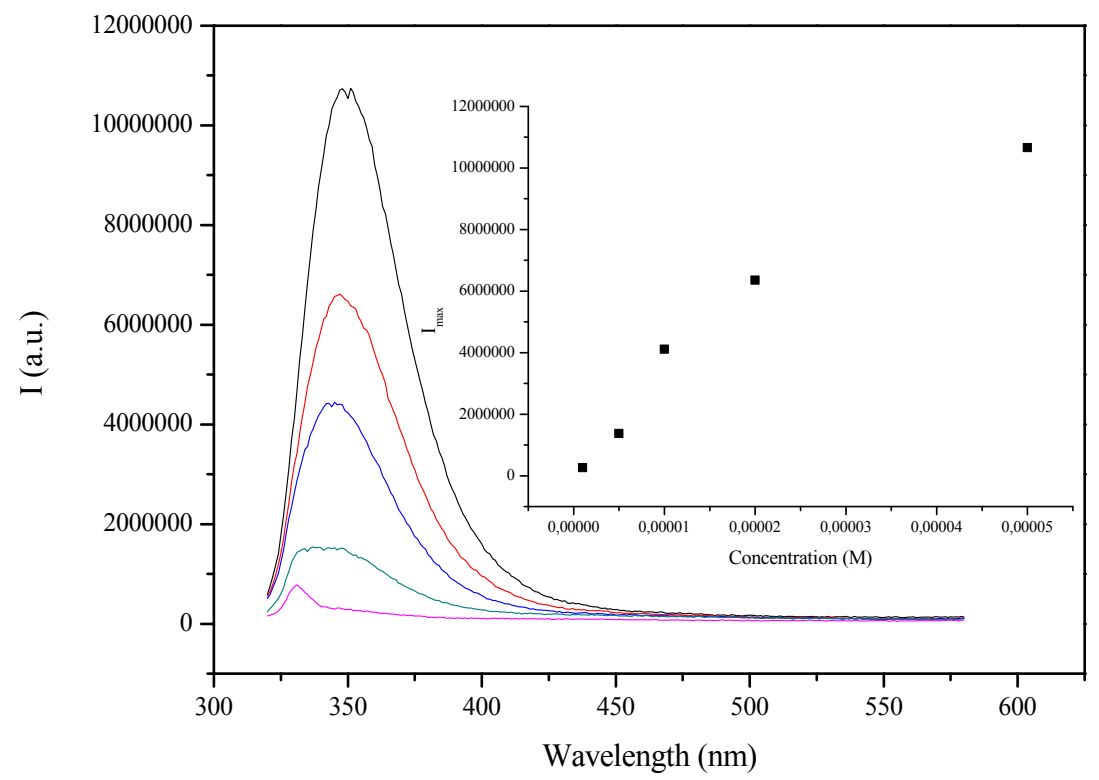

Figure S16. Emission spectra of 6 at different concentrations. 


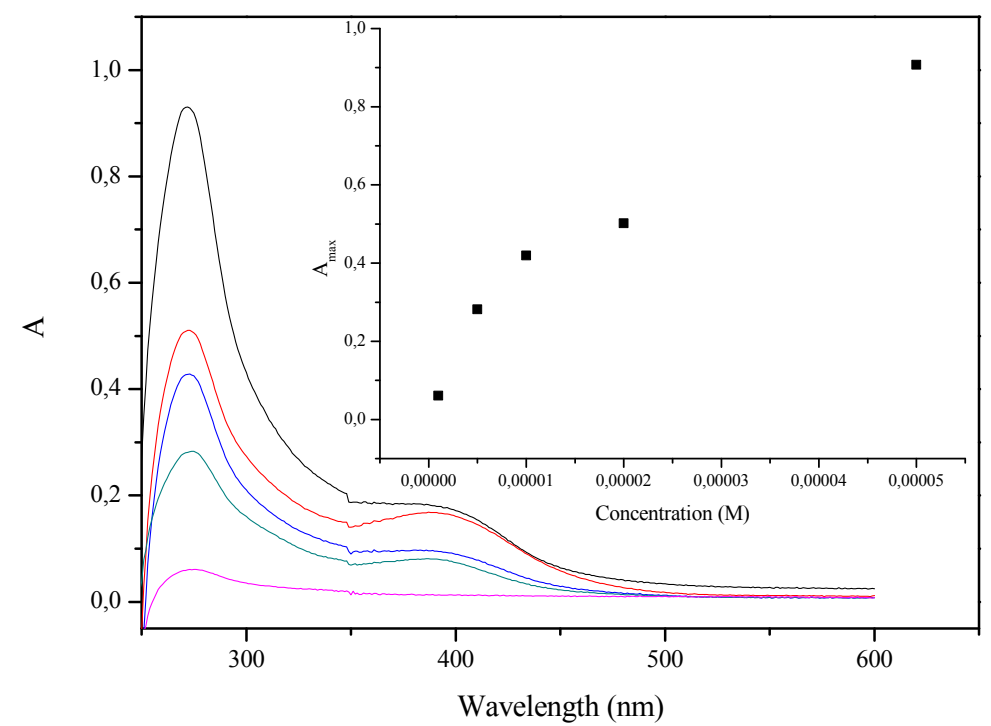

Figure S17. Absorption spectra of 7 at different concentrations.

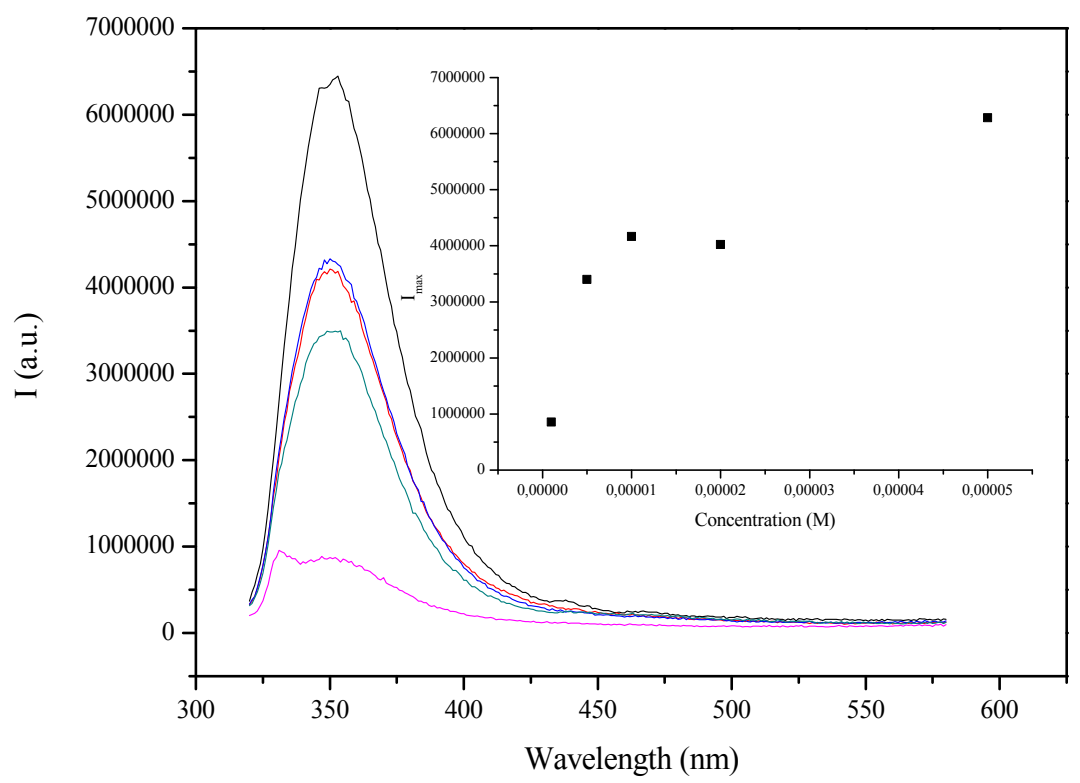

Figure S18. Emission spectra of 7 at different concentrations. 


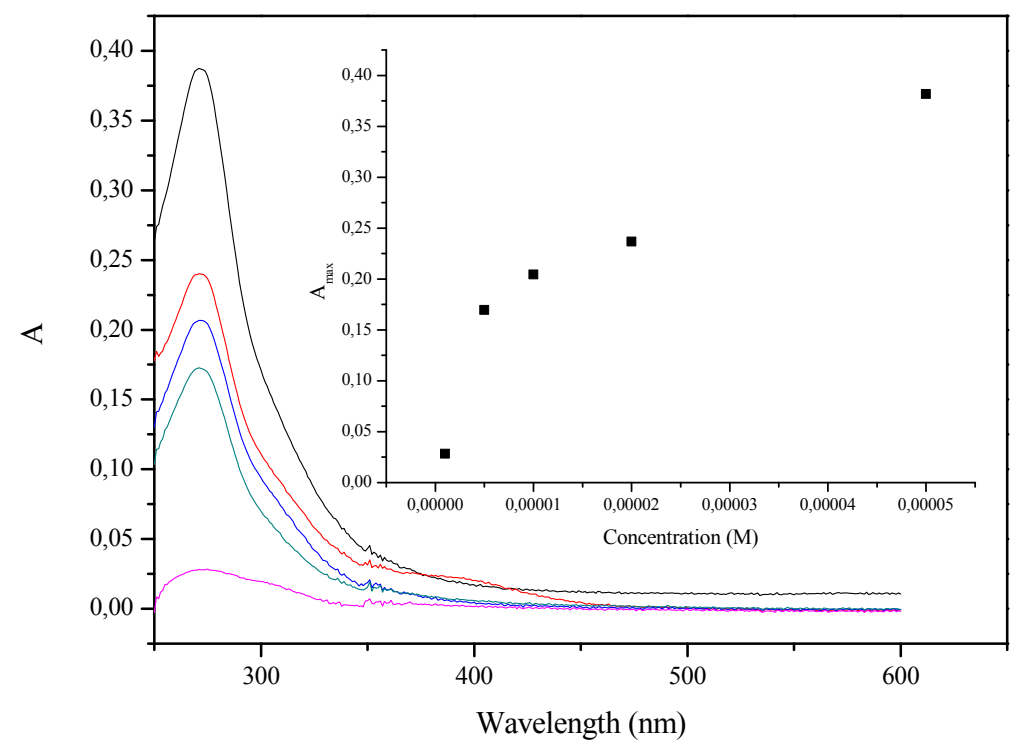

Figure S19. Absorption spectra of 8 at different concentrations.

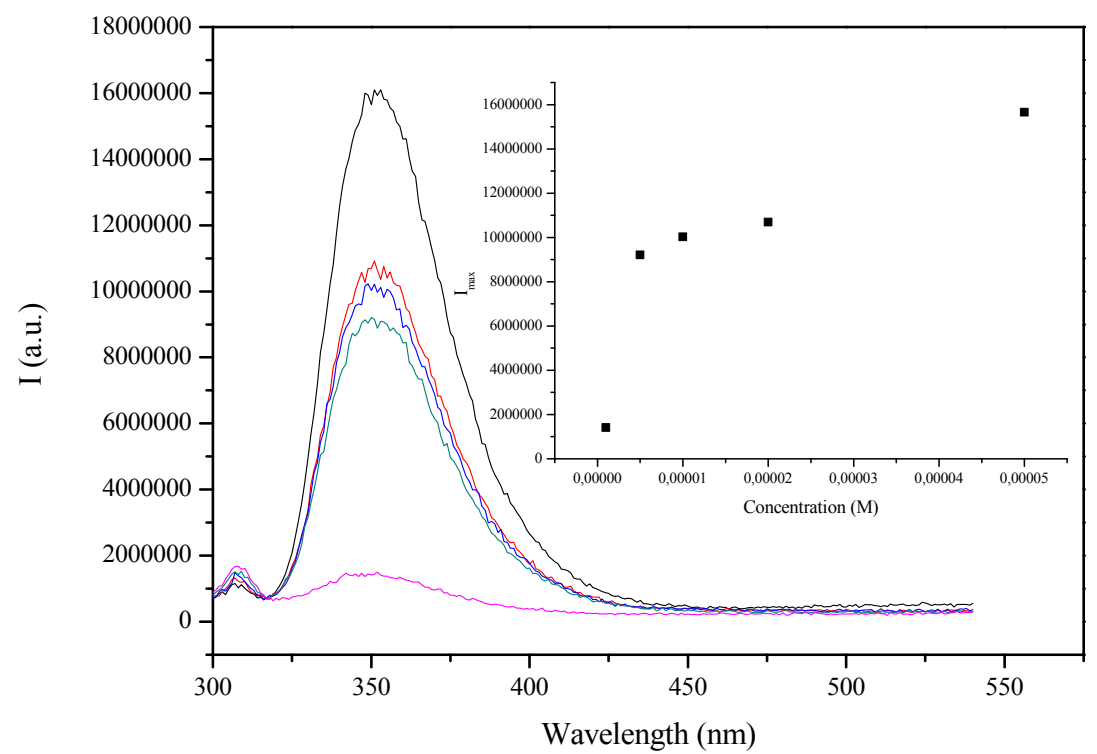

Figure S20. Emission spectra of $\mathbf{8}$ at different concentrations. 


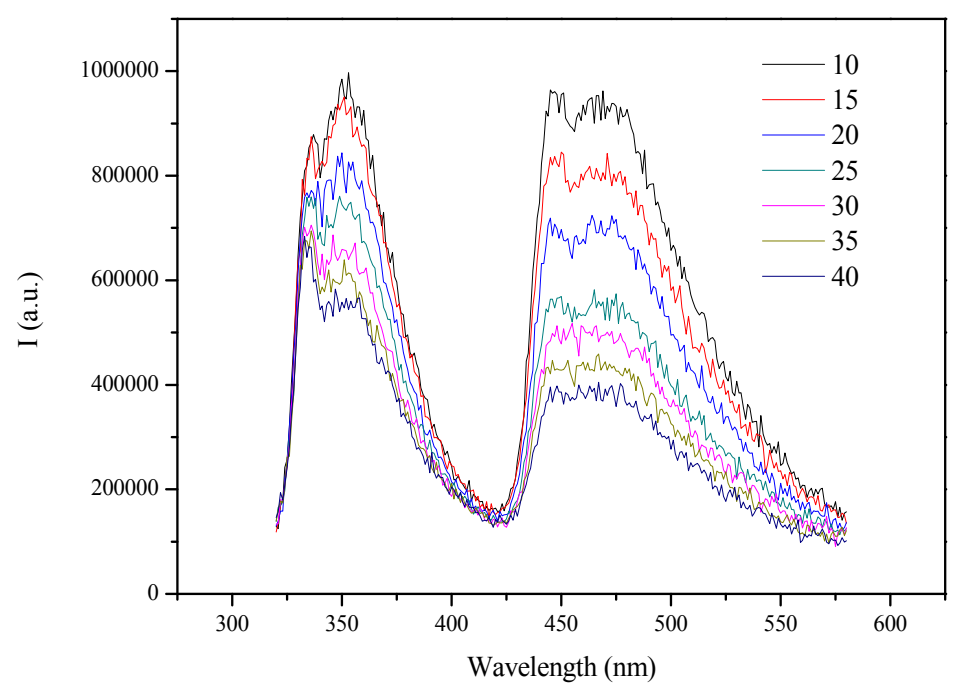

Figure S21. Emission spectra of a $10^{-5} \mathrm{M}$ solution of $\mathbf{1}$ at different temperatures $\left({ }^{\circ} \mathrm{C}\right)$.

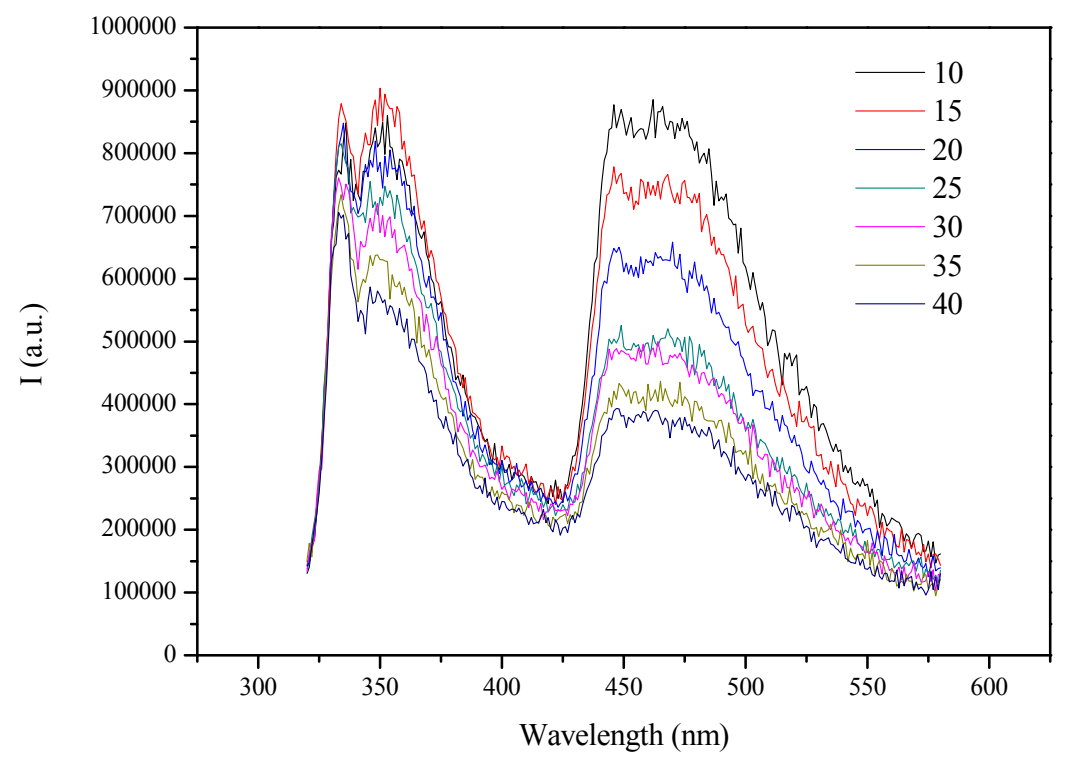

Figure S22. Emission spectra of a $10^{-5} \mathrm{M}$ solution of $\mathbf{2}$ at different temperatures $\left({ }^{\circ} \mathrm{C}\right)$. 


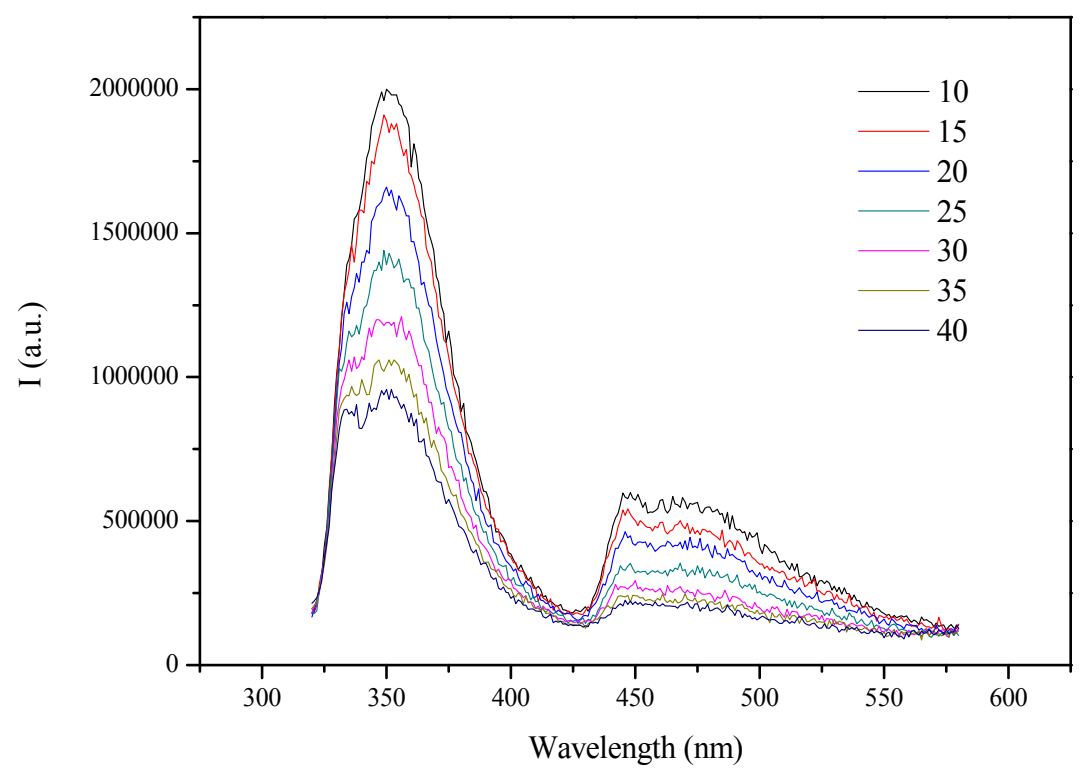

Figure S23. Emission spectra of a $10^{-5} \mathrm{M}$ solution of 4 at different temperatures $\left({ }^{\circ} \mathrm{C}\right)$.

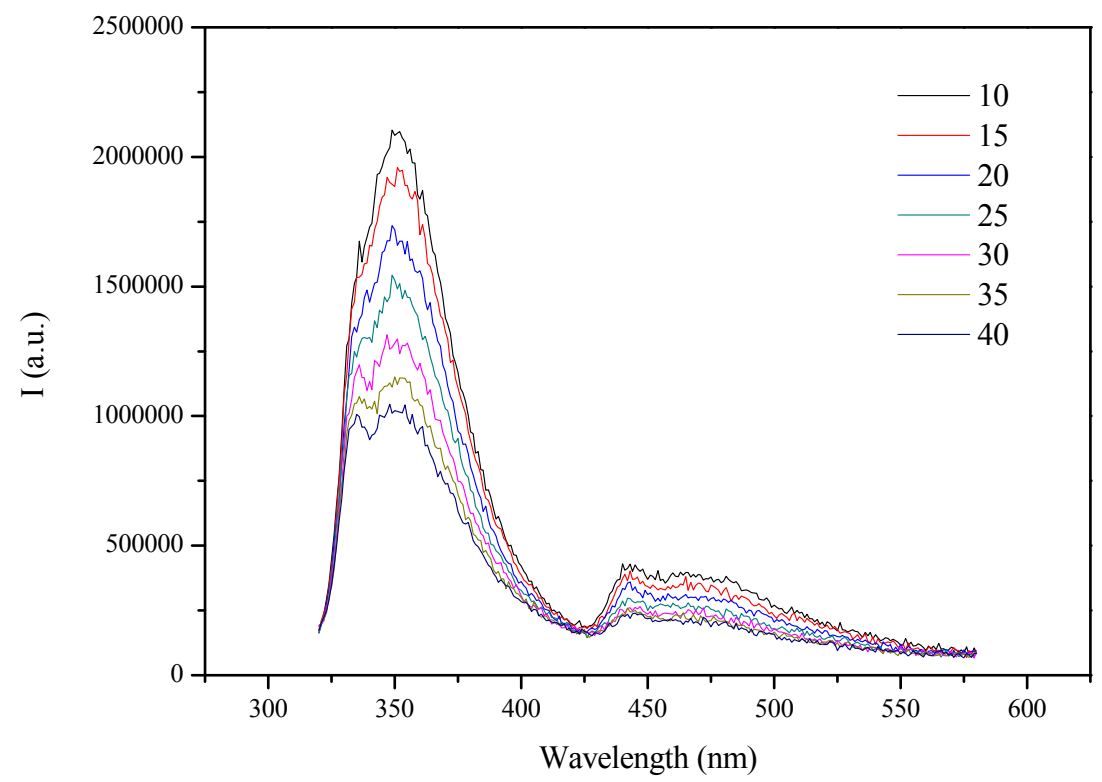

Figure S24. Emission spectra of a $10^{-5} \mathrm{M}$ solution of 5 at different temperatures $\left({ }^{\circ} \mathrm{C}\right)$. 


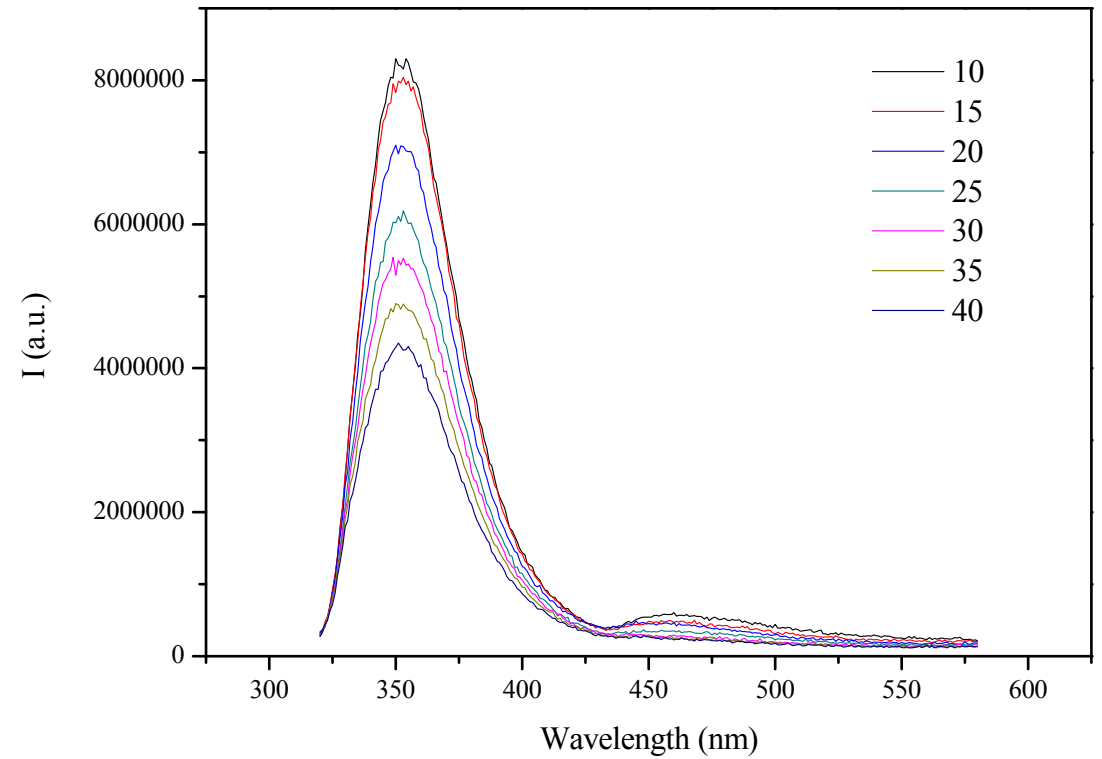

Figure S25. Emission spectra of a $10^{-5} \mathrm{M}$ solution of 7 at different temperatures $\left({ }^{\circ} \mathrm{C}\right)$. 


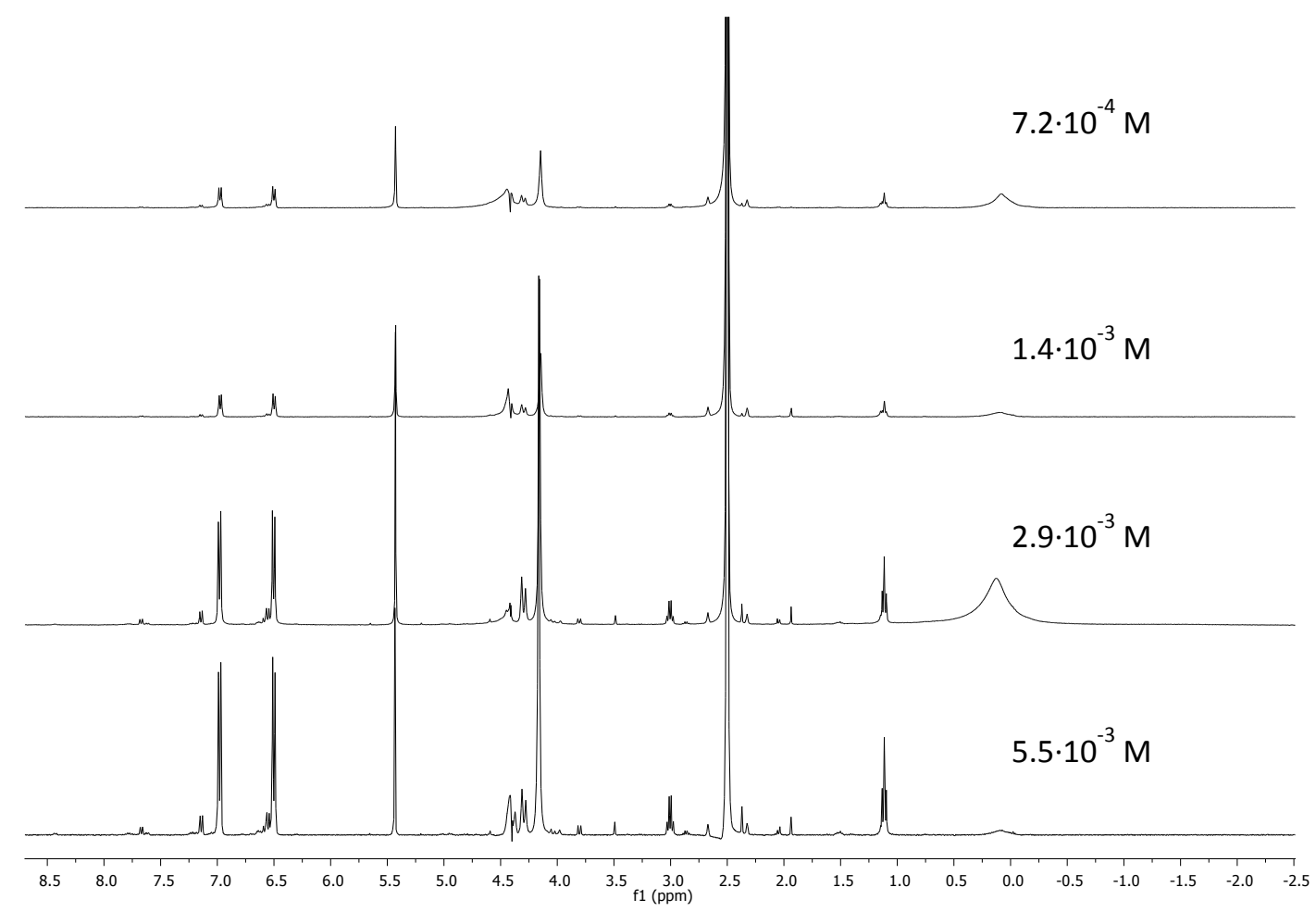

Figure S26. ${ }^{1} \mathrm{H}-\mathrm{NMR}$ spectra of $\mathbf{1}$ at different concentrations in a mixture of $\mathrm{D}_{2} \mathrm{O}: \mathrm{DMSO}-d_{6}$.

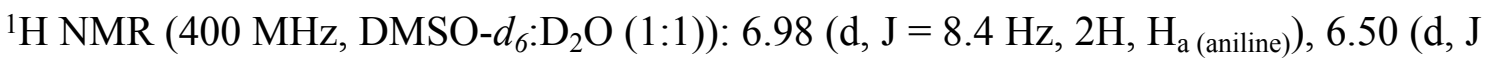

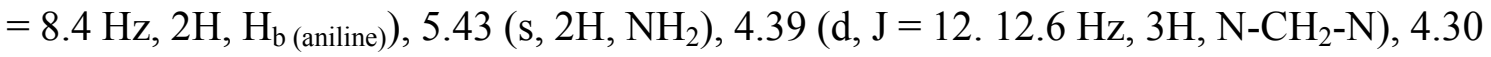
(d, J = $\left.12.8 \mathrm{~Hz}, 3 \mathrm{H}, \mathrm{N}-\mathrm{CH}_{2}-\mathrm{N}\right), 4.17$ (s, 6H, N-CH $\left.2-\mathrm{P}\right)$.

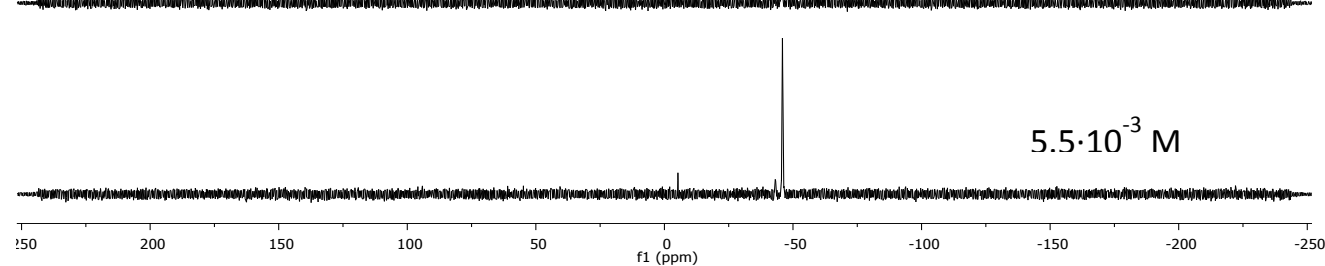

Figure S27. ${ }^{31} \mathrm{P}\left\{{ }^{1} \mathrm{H}\right\}-\mathrm{NMR}$ spectra of $\mathbf{1}$ at different concentrations in a mixture of $\mathrm{D}_{2} \mathrm{O}: \mathrm{DMSO}-d_{6}$. 


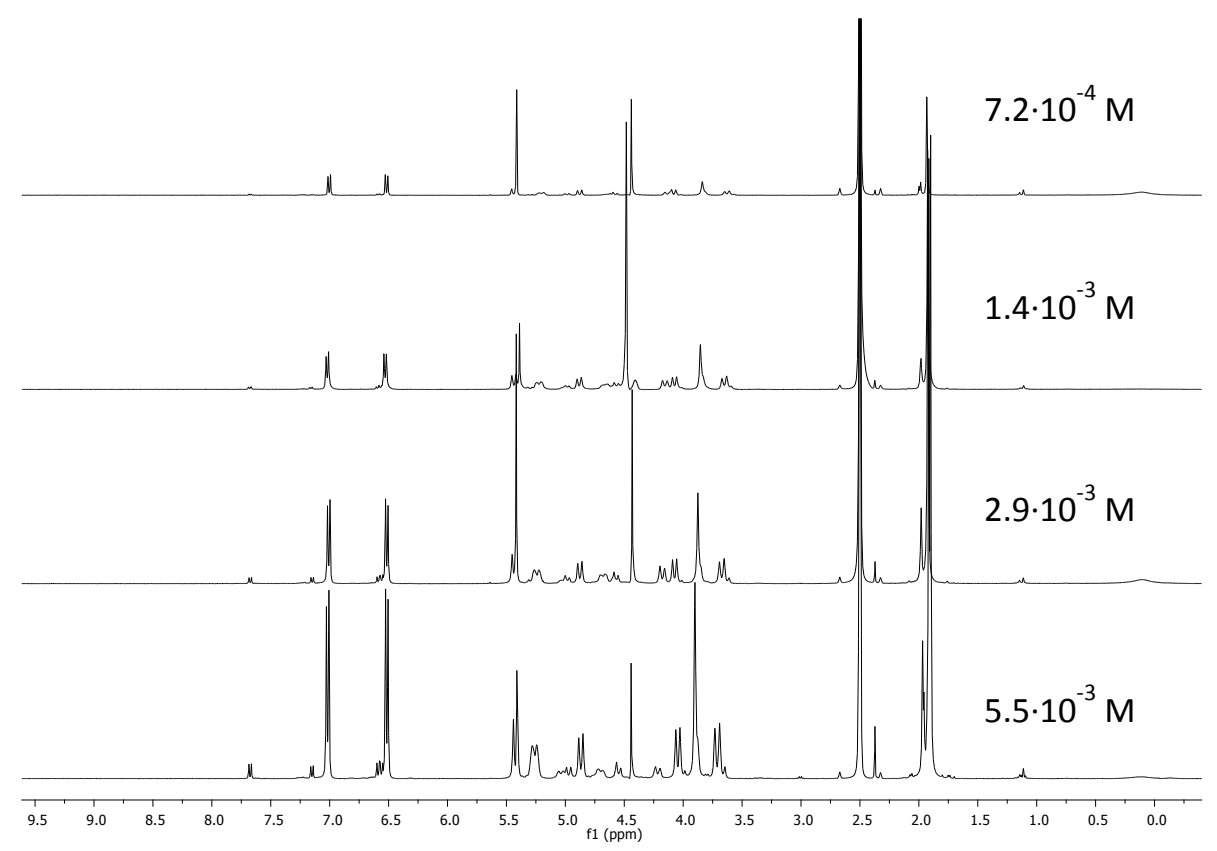

Figure S28. ${ }^{1} \mathrm{H}-\mathrm{NMR}$ spectra of $\mathbf{2}$ at different concentrations in a mixture of $\mathrm{D}_{2} \mathrm{O}: \mathrm{DMSO}-d_{6}$.

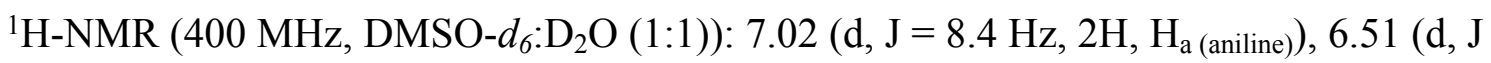

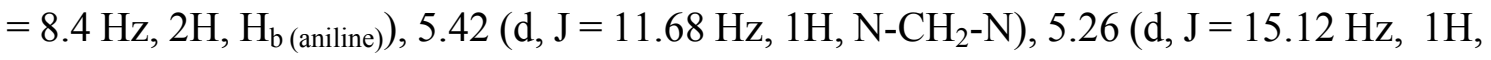
P-CH $2-\mathrm{N}), 4.86\left(\mathrm{~d}, \mathrm{~J}=14.20 \mathrm{~Hz}, 1 \mathrm{H}, \mathrm{N}-\mathrm{CH}_{2}-\mathrm{N}\right), 4.73-4.67\left(\mathrm{~m}, 1 \mathrm{H}, \mathrm{N}-\mathrm{CH}_{2}-\mathrm{N}\right), 4.55(\mathrm{~d}, \mathrm{~J}$ $\left.=14.00 \mathrm{~Hz}, 1 \mathrm{H}, \mathrm{P}-\mathrm{CH}_{2}-\mathrm{N}\right), 4.44\left(\mathrm{~s}, 2 \mathrm{H}, \mathrm{NH}_{2}\right), 4.22\left(\mathrm{~d}, \mathrm{~J}=15.48 \mathrm{~Hz}, 1 \mathrm{H}, \mathrm{P}^{\left.-\mathrm{CH}_{2}-\mathrm{N}\right), 4.04}\right.$ $\left(\mathrm{d}, \mathrm{J}=14.04 \mathrm{~Hz}, 1 \mathrm{H}, \mathrm{N}-\mathrm{CH}_{2}-\mathrm{N}\right), 3.90\left(\mathrm{~s}, 2 \mathrm{H}, \mathrm{P}-\mathrm{CH}_{2}-\mathrm{N}\right), 3.71\left(\mathrm{~d}, \mathrm{~J}=16.2 \mathrm{~Hz}, 1 \mathrm{H}, \mathrm{P}^{-\mathrm{CH}_{2}-}\right.$ $\mathrm{N}), 1.91\left(\mathrm{~d}, \mathrm{~J}=3.9 \mathrm{~Hz}, 6 \mathrm{H}, \mathrm{CO}-\mathrm{CH}_{3}\right)$. 


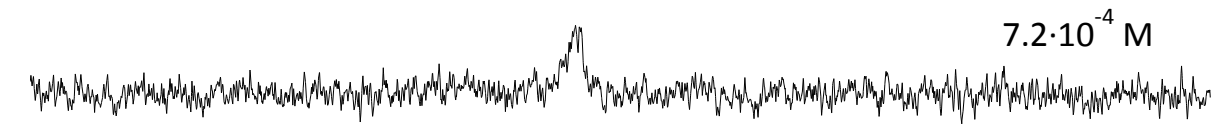

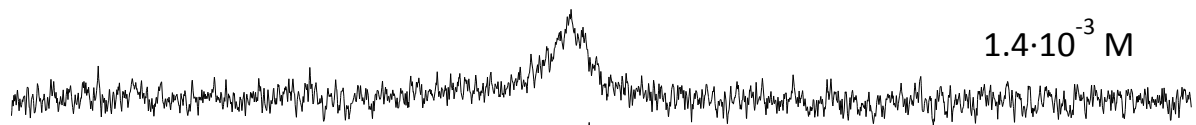

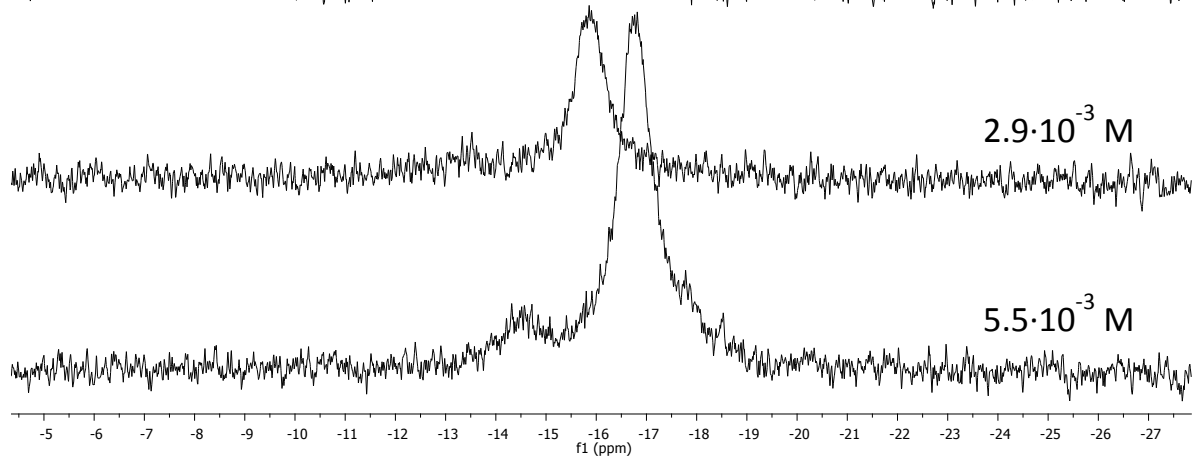

Figure S29. ${ }^{31} \mathrm{P}\left\{{ }^{1} \mathrm{H}\right\}$-NMR spectra of 2 at different concentrations in a mixture of $\mathrm{D}_{2} \mathrm{O}: \mathrm{DMSO}-d_{6}$. 

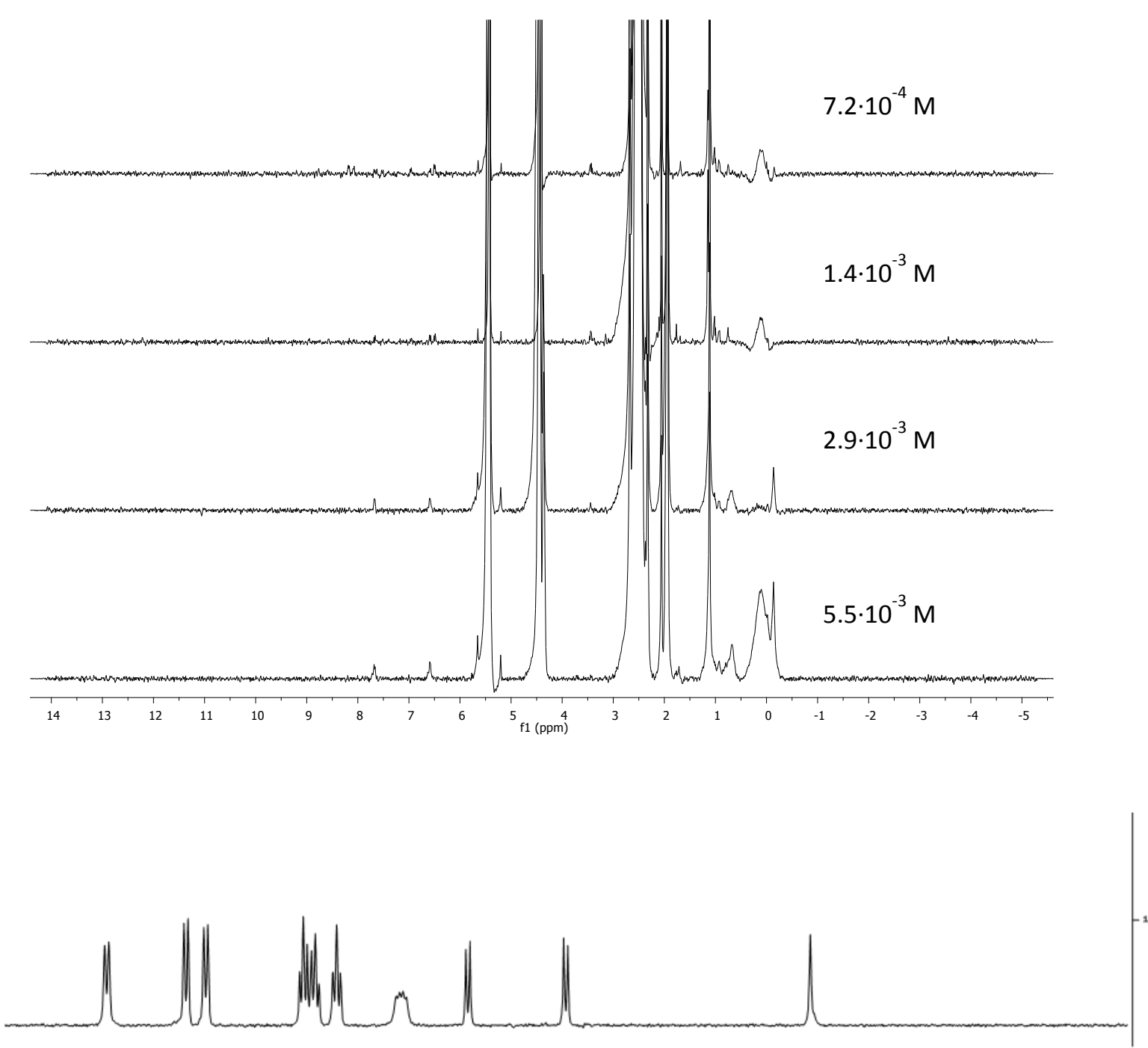

Figure S30. ${ }^{1} \mathrm{H}$ NMR spectra of $\mathbf{3}$ at different concentrations in a mixture of $\mathrm{D}_{2} \mathrm{O}$ :DMSO- $d_{6}$ (above). ${ }^{1} \mathrm{H}$ NMR spectra of 3 in DMSO- $d_{6}$ (below).

${ }^{1} \mathrm{H}$ NMR (400 MHz, DMSO-d 6 ): 8.66 (d, J = 8.28 Hz, 3H, HNaph), 8.27 (d, J = 8.16 Hz, 3H, HNaph), 8.17 (d, J = 8.04 Hz, 3H, HNaph), 7.69 (t, J = 7.04 Hz, 3H, HNaph), 7.63 (t, J = 7.48 Hz, 3H, HNaph), 7.52 (t, J = 7.28 Hz, 3H, HNaph), 7.23-7.18 (m, 3H, HNaph), $6.86\left(\mathrm{~d}, \mathrm{~J}=8.4 \mathrm{~Hz}, 2 \mathrm{H}, \mathrm{H}_{\mathrm{a}}\right), 6.39\left(\mathrm{~d}, \mathrm{~J}=8.4 \mathrm{~Hz}, 2 \mathrm{H}, \mathrm{H}_{\mathrm{b}}\right), 5.17\left(\mathrm{~s}, 2 \mathrm{H}, \mathrm{NH}_{2}\right)$.

1) (only $\mathrm{NH}_{2}$ peaks are observed in $\mathrm{D}_{2} \mathrm{O}$ and for this reason the assignment is here displayed in DMSO- $d_{6}$.

2) The low solubility of the compound in the presence of small amounts of $D_{2} \mathrm{O}$ precludes to record ${ }^{31} \mathrm{P}$ NMR spectra under the same conditions followed for the rest of compounds. 

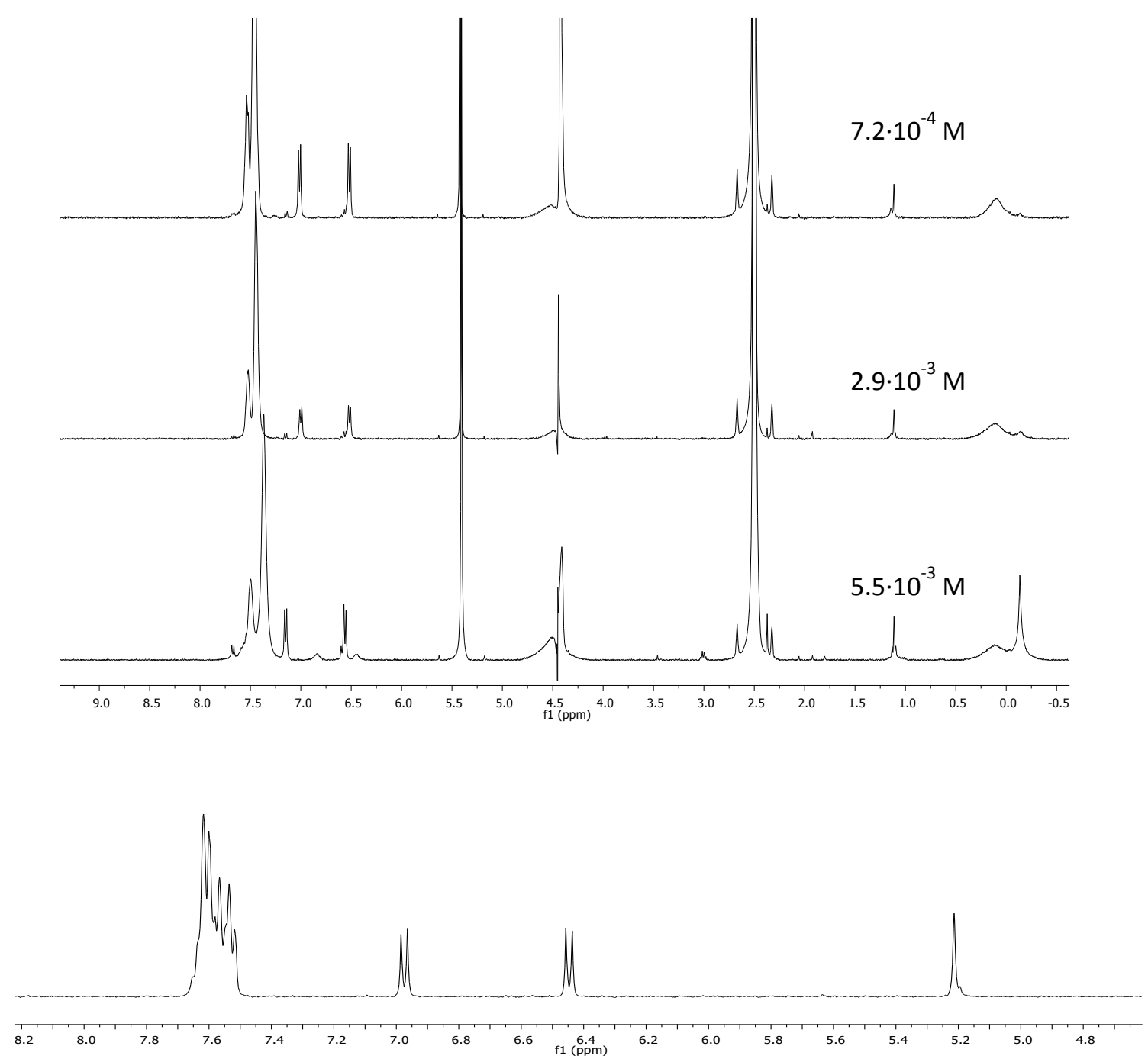

Figure S31. ${ }^{1} \mathrm{H}-\mathrm{NMR}$ spectra of $\mathbf{4}$ at different concentrations in a mixture of $\mathrm{D}_{2} \mathrm{O}: \mathrm{DMSO}-d_{6}$ (above). ${ }^{1} \mathrm{H}$ NMR spectra of 4 in DMSO- $d_{6}$ (below).

${ }^{1} \mathrm{H}$ NMR (400 MHz, DMSO- $\left.d_{6}: \mathrm{D}_{2} \mathrm{O}(1: 1)\right): 7.56-7.42$ (m, 15H, Ph), 7.01 (d, J = 8.4 Hz, $\left.2 \mathrm{H}, \mathrm{H}_{\mathrm{a}}\right), 6.52\left(\mathrm{~d}, \mathrm{~J}=8.4 \mathrm{~Hz}, 2 \mathrm{H}, \mathrm{H}_{\mathrm{b}}\right), 5.42\left(\mathrm{~s}, 2 \mathrm{H}, \mathrm{NH}_{2}\right)$.

1) Broad signals are observed in DMSO- $d_{6}: \mathrm{D}_{2} \mathrm{O}(1: 1)$ mixtures and the correct formation of the complex was confirm in pure DMSO- $d_{6}$. 


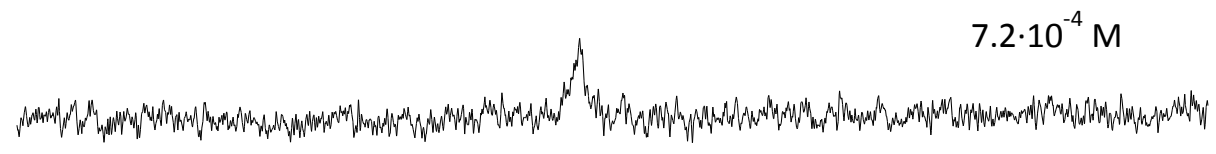

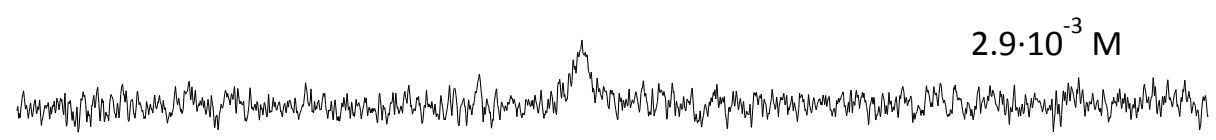

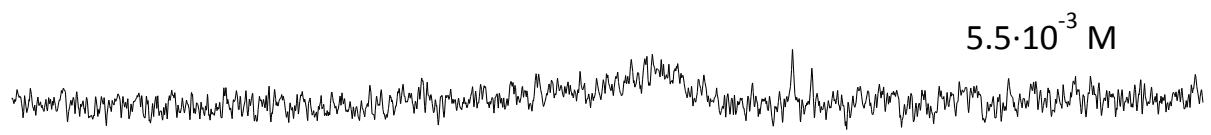

\begin{tabular}{lllllllllllllllllllllll}
\hline 64 & 62 & 60 & 58 & 56 & 54 & 52 & 50 & 48 & 46 & 44 & $\begin{array}{c}42 \\
11(\operatorname{pom})^{40}\end{array}$ & 38 & 36 & 34 & 32 & 30 & 28 & 26 & 24 & 22 & 20
\end{tabular}

Figure S32. ${ }^{31} \mathrm{P}\left\{{ }^{1} \mathrm{H}\right\}$-NMR spectra of 4 at different concentrations in a mixture of $\mathrm{D}_{2} \mathrm{O}: \mathrm{DMSO}-d_{6}$. 


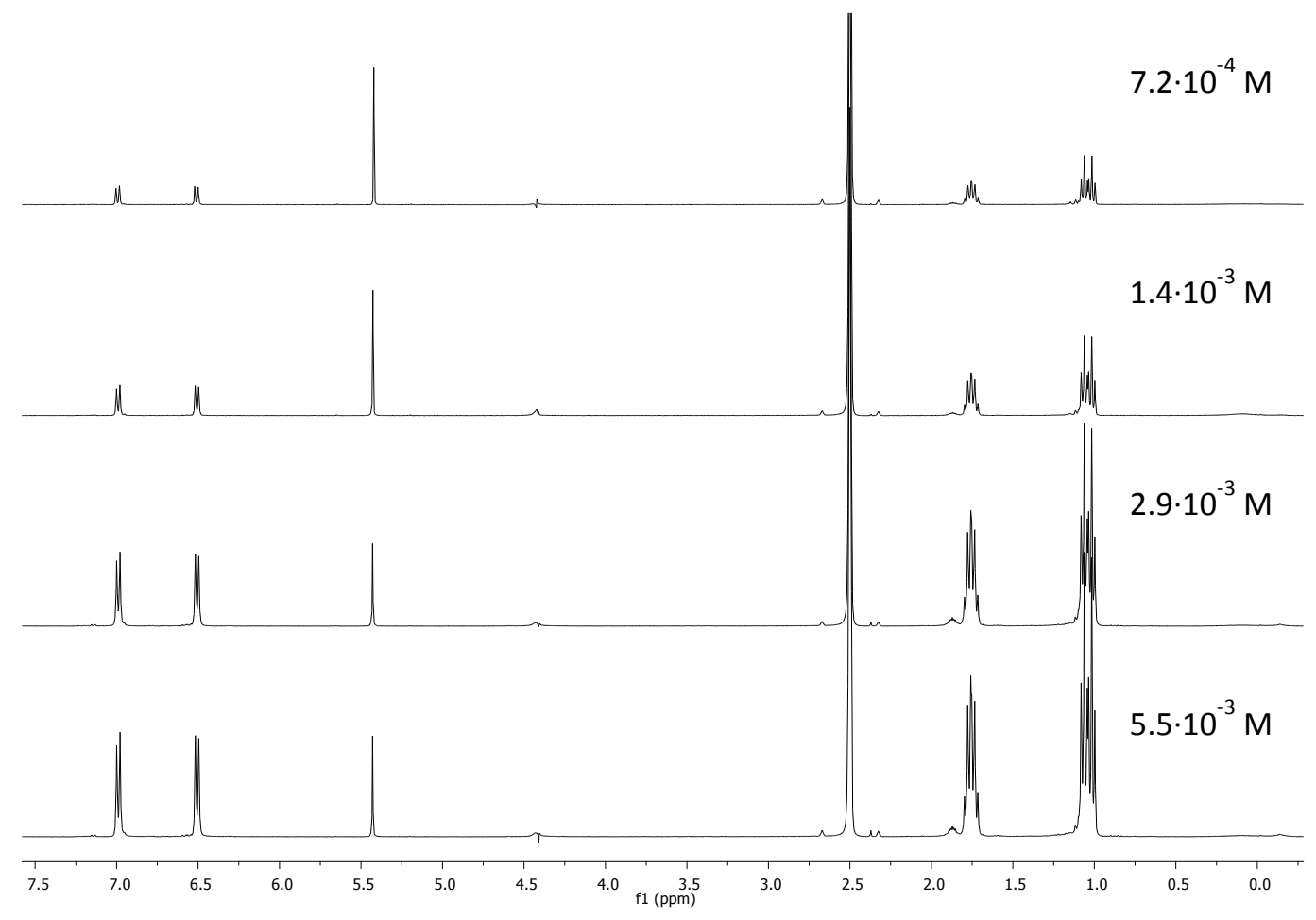

Figure S33. ${ }^{1} \mathrm{H}-\mathrm{NMR}$ spectra of 5 at different concentrations in a mixture of $\mathrm{D}_{2} \mathrm{O}: \mathrm{DMSO}-d_{6}$.

${ }^{1} \mathrm{H}$ NMR (400 MHz, DMSO- $\left.d_{6}: \mathrm{D}_{2} \mathrm{O}(1: 1)\right): 6.99$ (d, J = 8.4 Hz, 2H, $\mathrm{H}_{\mathrm{a}}$ ), 6.50 (d, J = 8.4 $\mathrm{Hz}, 2 \mathrm{H}, \mathrm{H}_{\mathrm{b}}$ ), 5.43 (s, 2H, NH ), 1.76 (q, J = 7.68 Hz, 6H, $\mathrm{CH}_{2}$ ), 1.04 (dt, J = $18.44 \mathrm{~Hz}, \mathrm{~J}$ $\left.=7.56 \mathrm{~Hz}, 9 \mathrm{H}, \mathrm{CH}_{3}\right)$. 


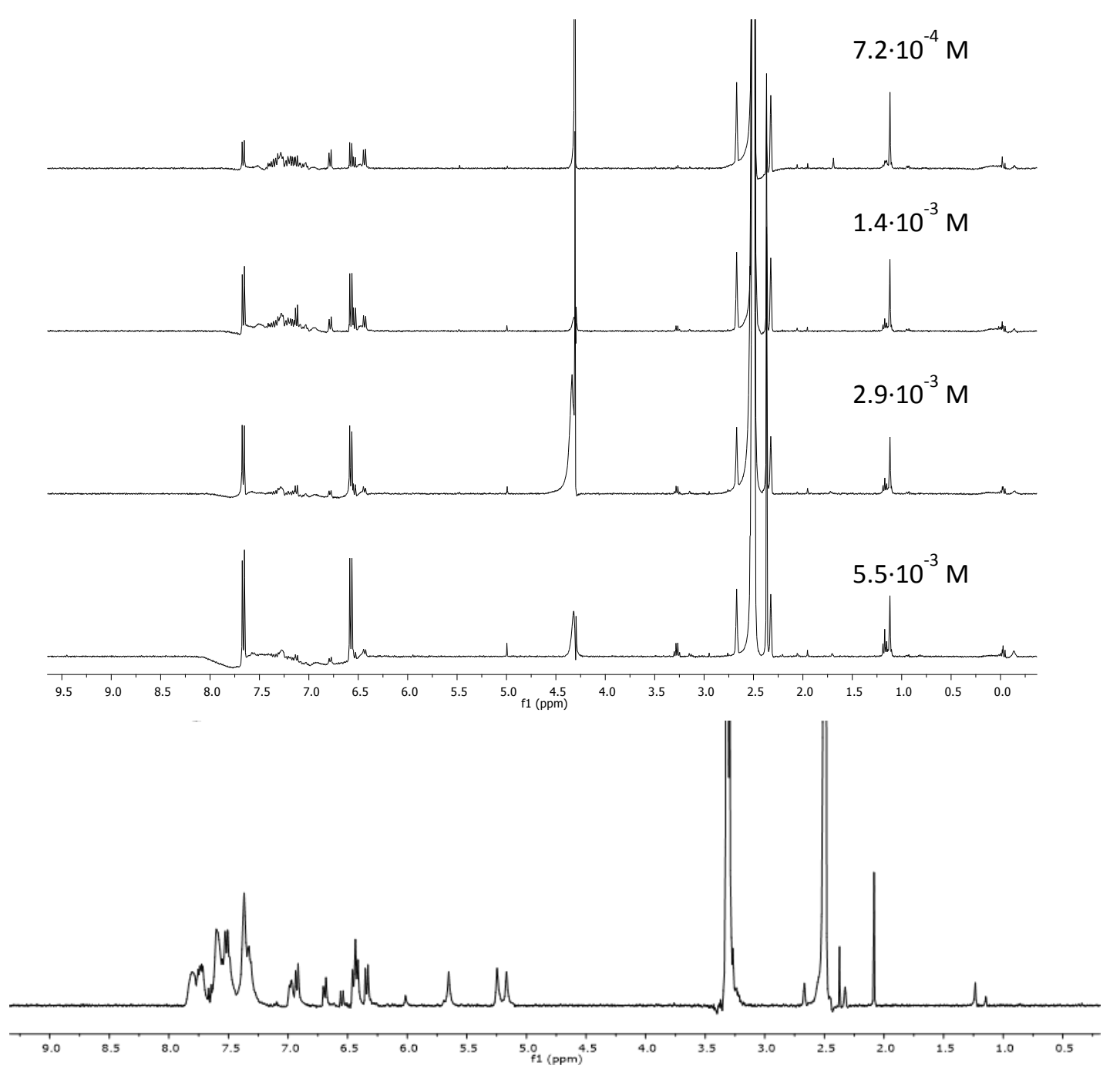

Figure S34. ${ }^{1} \mathrm{H}$ NMR spectra of 6 at different concentrations in a mixture of $\mathrm{D}_{2} \mathrm{O}$ :DMSO- $d_{6}$ (above). ${ }^{1} \mathrm{H}$ NMR spectra of 6 in DMSO- $d_{6}$ (below).

${ }^{1} \mathrm{H}$ NMR (400 MHz, DMSO- $\left.d_{6}\right): 7.82-7.31$ (m, 20H, Ph), $6.93\left(\mathrm{~d}, \mathrm{~J}=8.28 \mathrm{~Hz}, 4 \mathrm{H}, \mathrm{H}_{\mathrm{a}}\right.$ ), $6.34\left(\mathrm{~d}, \mathrm{~J}=8.4 \mathrm{~Hz}, 4 \mathrm{H}, \mathrm{H}_{\mathrm{b}}\right), 5.65\left(\mathrm{~s}, 4 \mathrm{H}, \mathrm{NH}_{2}\right)$.

1) Broad signals are observed in DMSO- $d_{6}: \mathrm{D}_{2} \mathrm{O}(1: 1)$ mixtures and for this reason, the assignment is done in pure DMSO- $d_{6}$ according to ref. 13.

2) The low solubility of the compound in the presence of small amounts of $\mathrm{D}_{2} \mathrm{O}$ precludes to record ${ }^{31} \mathrm{P}$ NMR spectra under the same conditions followed for the mononuclear compounds. 


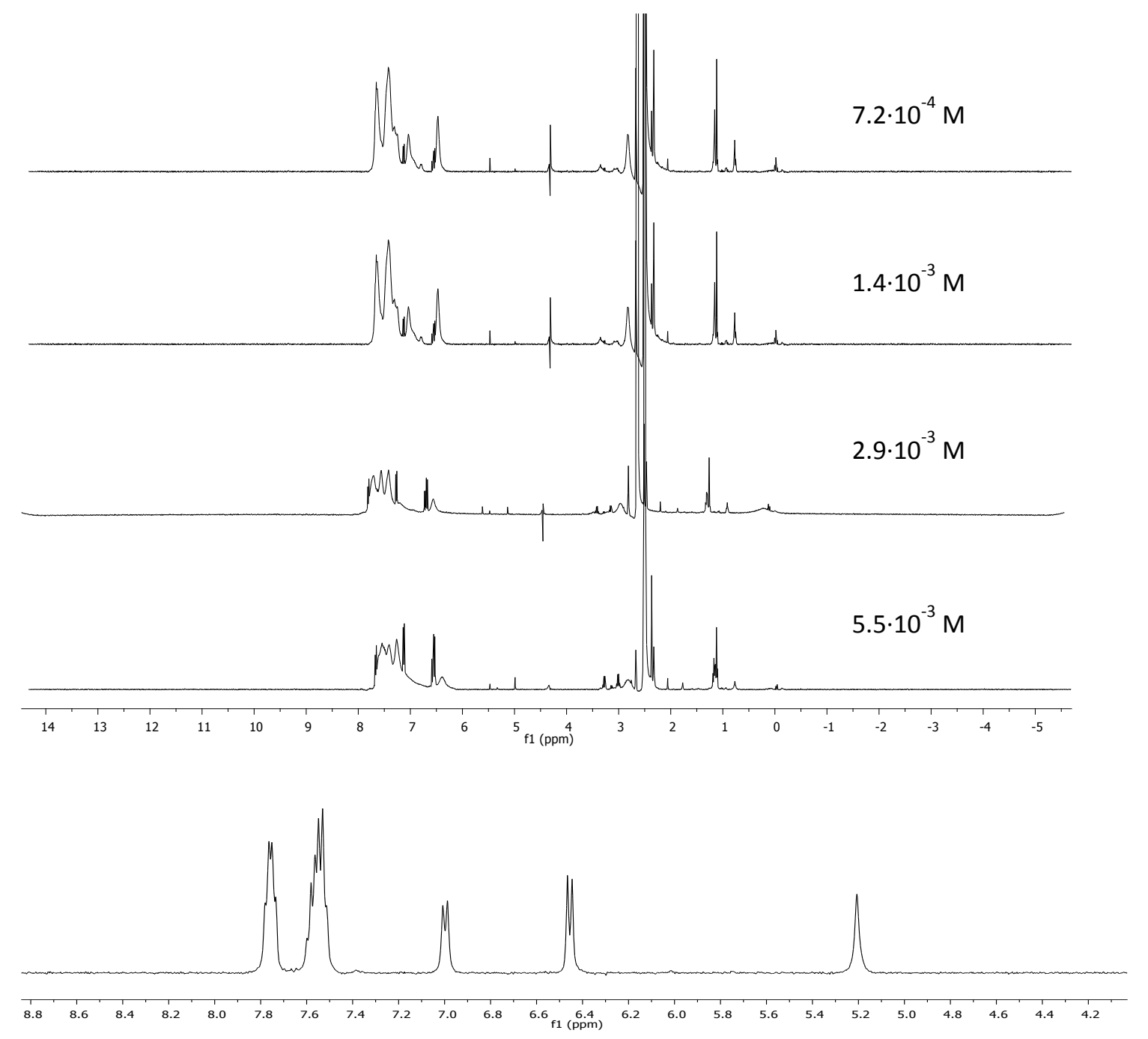

Figure S35 ${ }^{1} \mathrm{H}-\mathrm{NMR}$ spectra of 7 at different concentrations in a mixture of $\mathrm{D}_{2} \mathrm{O}$ :DMSO- $d_{6}$ (above). ${ }^{1} \mathrm{H}$ NMR spectra of 7 in DMSO- $d_{6}$ (below).

${ }^{1} \mathrm{H}$ NMR (400 MHz, DMSO-d $d_{6}$ ) 7.79-7.73 (m, 10H, Ph), 7.58-7.51 (m, 10H, Ph), 7.00 $\left(\mathrm{d}, \mathrm{J}=8.4 \mathrm{~Hz}, 4 \mathrm{H}, \mathrm{H}_{\mathrm{a}}\right), 6.45\left(\mathrm{~d}, \mathrm{~J}=8.4 \mathrm{~Hz}, 4 \mathrm{H}, \mathrm{H}_{\mathrm{b}}\right), 5.20\left(\mathrm{~s}, 4 \mathrm{H}, \mathrm{NH}_{2}\right), 2.08(\mathrm{~s}, 4 \mathrm{H}, \mathrm{P}-$ $\mathrm{CH}_{2}$ ).

1) Broad signals are observed in DMSO- $d_{6}: \mathrm{D}_{2} \mathrm{O}(1: 1)$ mixtures and for this reason, the assignment is done in pure DMSO- $d_{6}$ according to ref. 13.

2) The low solubility of the compound in the presence of small amounts of $D_{2} \mathrm{O}$ precludes to record ${ }^{31} \mathrm{P}$ NMR spectra under the same conditions followed for the mononuclear compounds. 

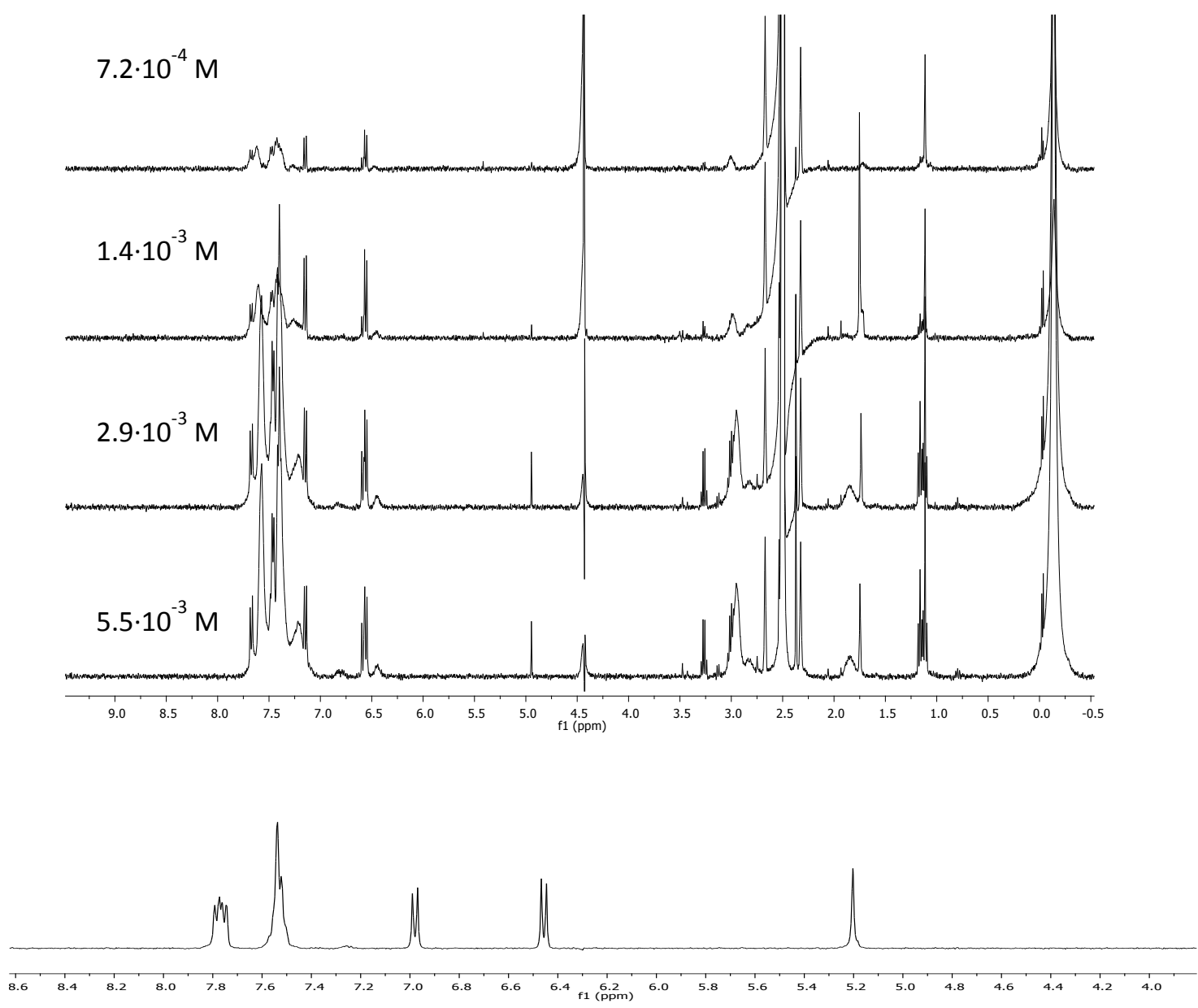

Figure S36. ${ }^{1} \mathrm{H}-\mathrm{NMR}$ spectra of 8 at different concentrations in a mixture of $\mathrm{D}_{2} \mathrm{O}: \mathrm{DMSO}-d_{6}$ (above). ${ }^{1} \mathrm{H}$ NMR spectra of 8 in DMSO- $d_{6}$ (below).

${ }^{1} \mathrm{H}$ NMR (400 MHz, DMSO-d $\left.d_{6}\right)$ 7.79-7.74 (m, 10H, Ph), 7.55-7.51 (m, 10H, Ph), 6.98 $\left(\mathrm{d}, \mathrm{J}=8.4 \mathrm{~Hz}, 4 \mathrm{H}, \mathrm{H}_{\mathrm{a}}\right), 6.46\left(\mathrm{~d}, \mathrm{~J}=8.4 \mathrm{~Hz}, 4 \mathrm{H}, \mathrm{H}_{\mathrm{b}}\right), 5.20\left(\mathrm{~s}, 4 \mathrm{H}, \mathrm{NH}_{2}\right), 3.07-3.01(\mathrm{~m}, 4 \mathrm{H}$, P- $\left.\mathrm{CH}_{2}-\mathrm{CH}_{2}-\mathrm{CH}_{2}-\mathrm{P}\right)$ 1.76-1.69 (m, 2H, P-CH$\left.-\mathrm{CH}_{2}-\mathrm{CH}_{2}-\mathrm{P}\right)$.

1) Broad signals are observed in DMSO- $d_{6}: \mathrm{D}_{2} \mathrm{O}(1: 1)$ mixtures and for this reason, the assignment is done in pure DMSO- $d_{6}$ according to ref. 13.

2) The low solubility of the compound in the presence of small amounts of $D_{2} \mathrm{O}$ precludes to record ${ }^{31} \mathrm{P}$ NMR spectra under the same conditions followed for the mononuclear compounds. 


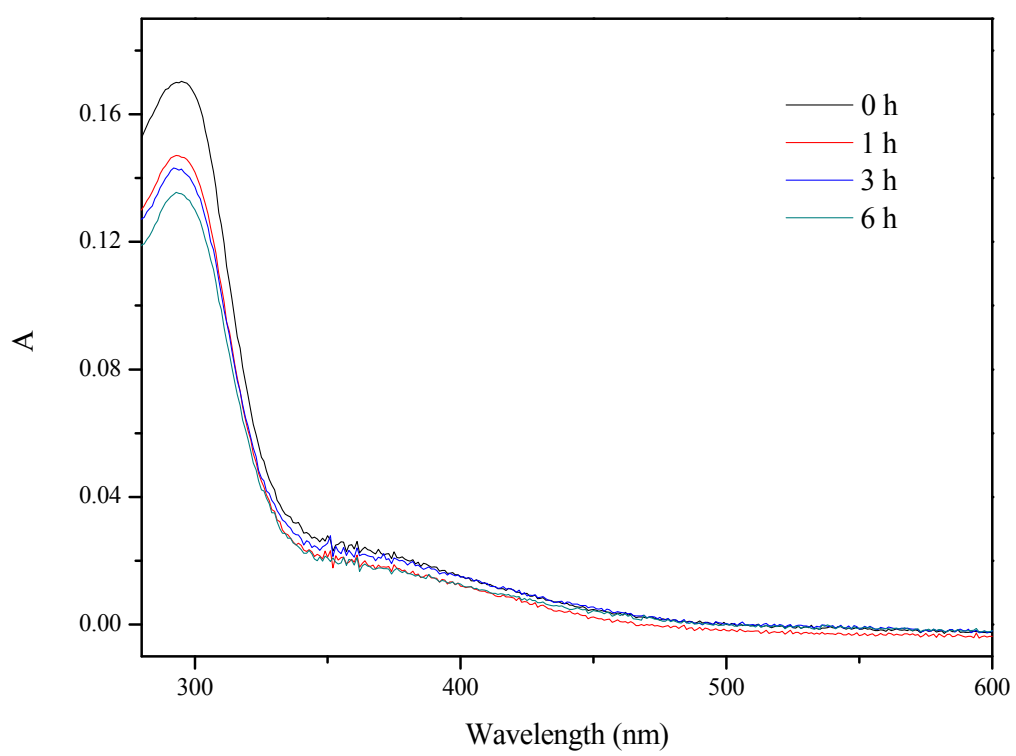

Figure S37. Absorption spectra of a $10^{-5} \mathrm{M}$ aqueous solution (containing $0.1 \%$ DMSO) of $\mathbf{1}$ at different times.

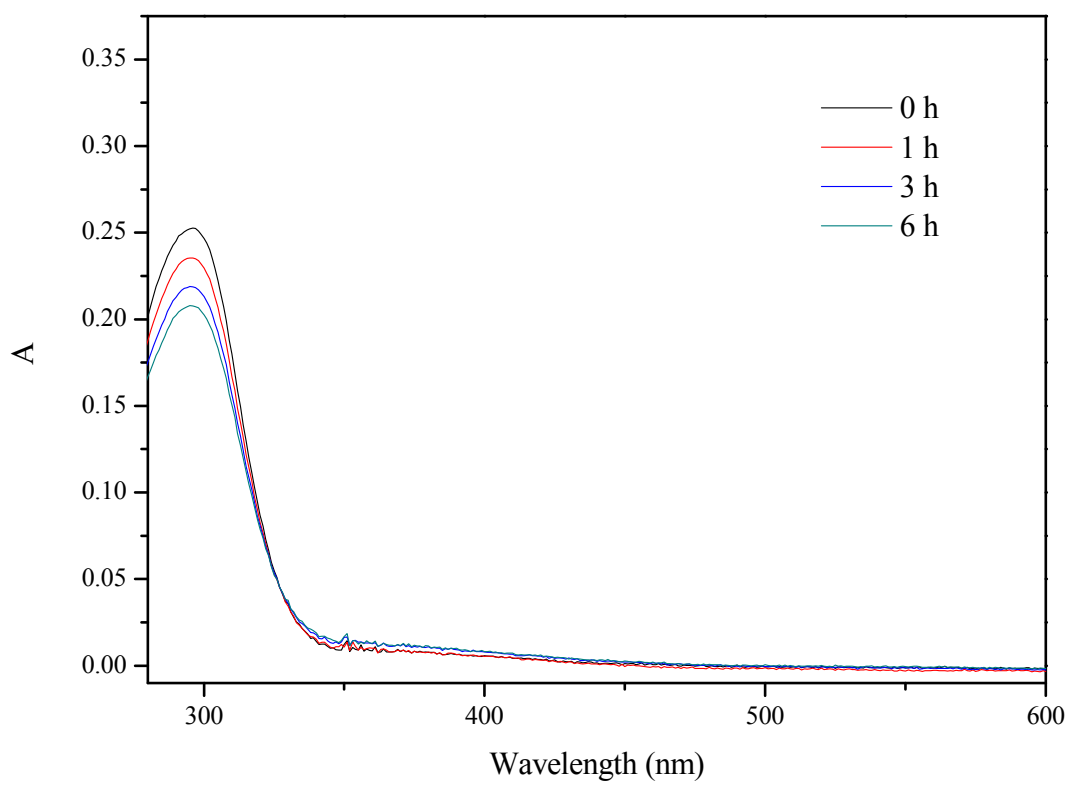

Figure S38. Absorption spectra of a $10^{-5} \mathrm{M}$ aqueous solution (containing $0.1 \%$ DMSO) of $\mathbf{2}$ at different times. 


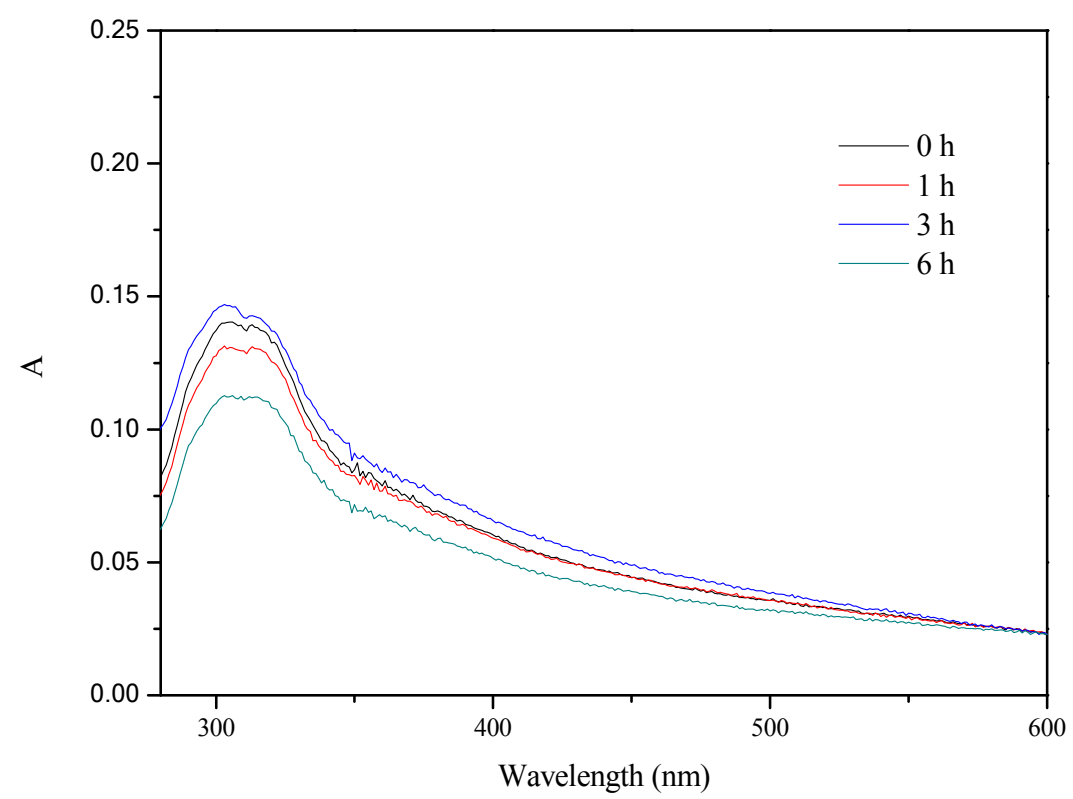

Figure S39. Absorption spectra of a $10^{-5} \mathrm{M}$ aqueous solution (containing $0.1 \%$ DMSO) of $\mathbf{3}$ at different times.

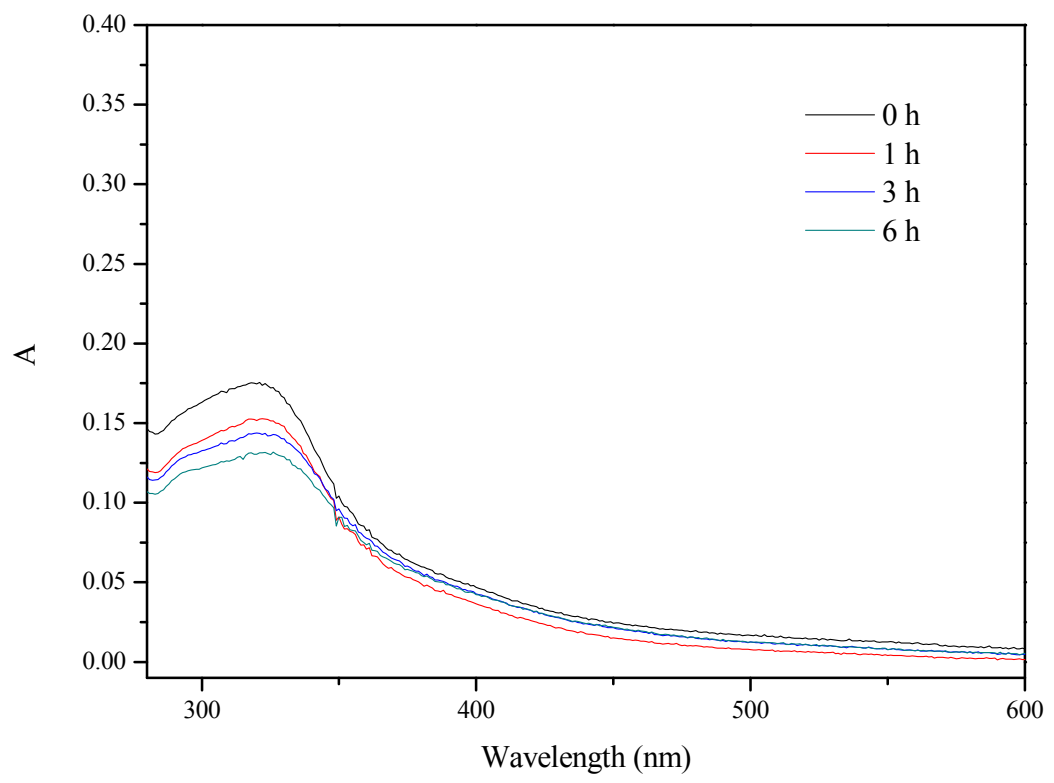

Figure S40. Absorption spectra of a $10^{-5} \mathrm{M}$ aqueous solution (containing 0.1\% DMSO) of 4 at different times. 


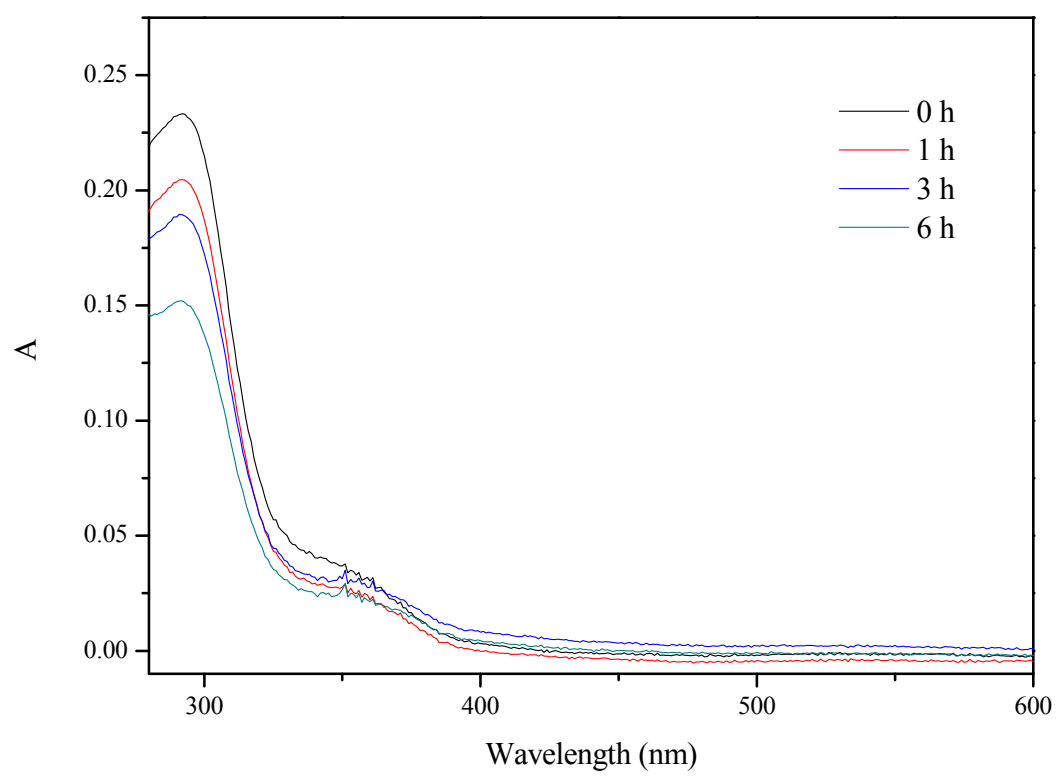

Figure S41. Absorption spectra of a $10^{-5} \mathrm{M}$ aqueous solution (containing 0.1\% DMSO) of 5 at different times.

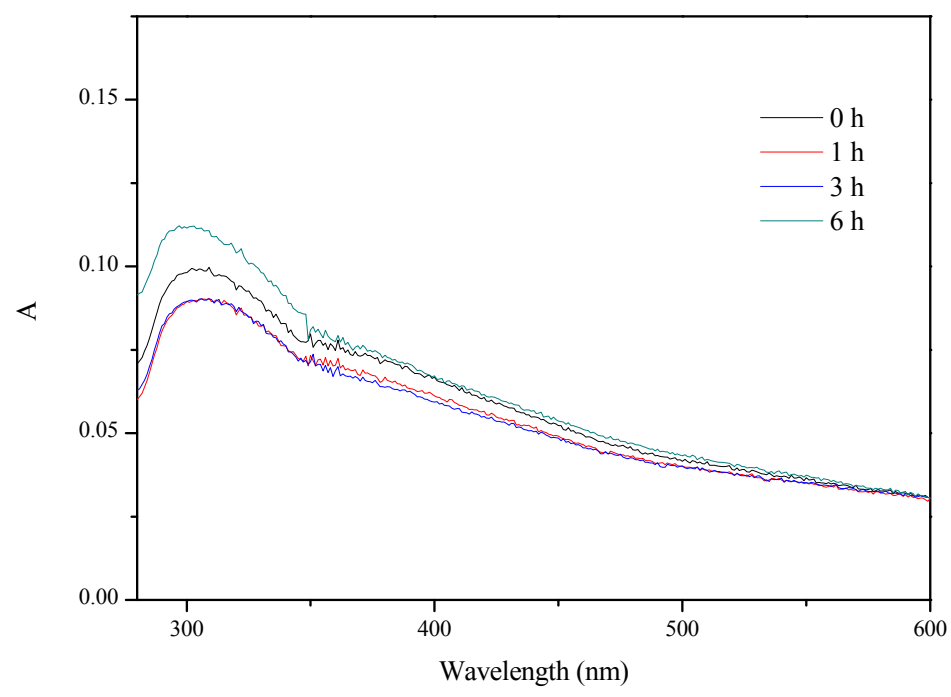

Figure S42. Absorption spectra of a $10^{-5} \mathrm{M}$ aqueous solution (containing 0.1\% DMSO) of 6 at different times. 


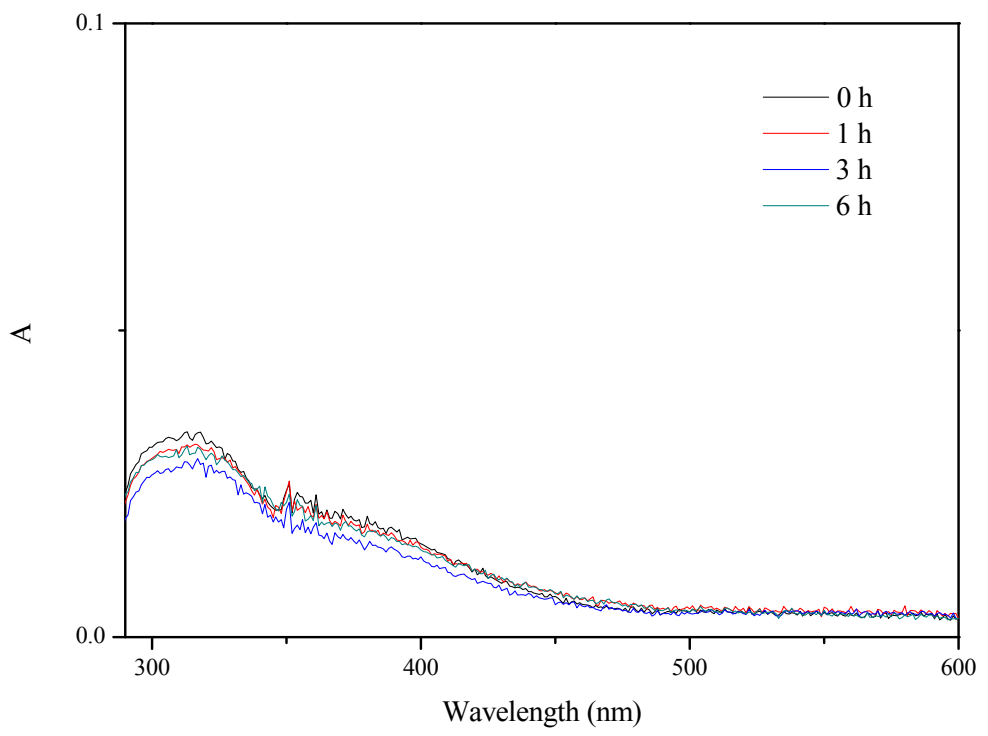

Figure S43. Absorption spectra of a $10^{-5} \mathrm{M}$ aqueous solution (containing $0.1 \%$ DMSO) of 7 at different times.

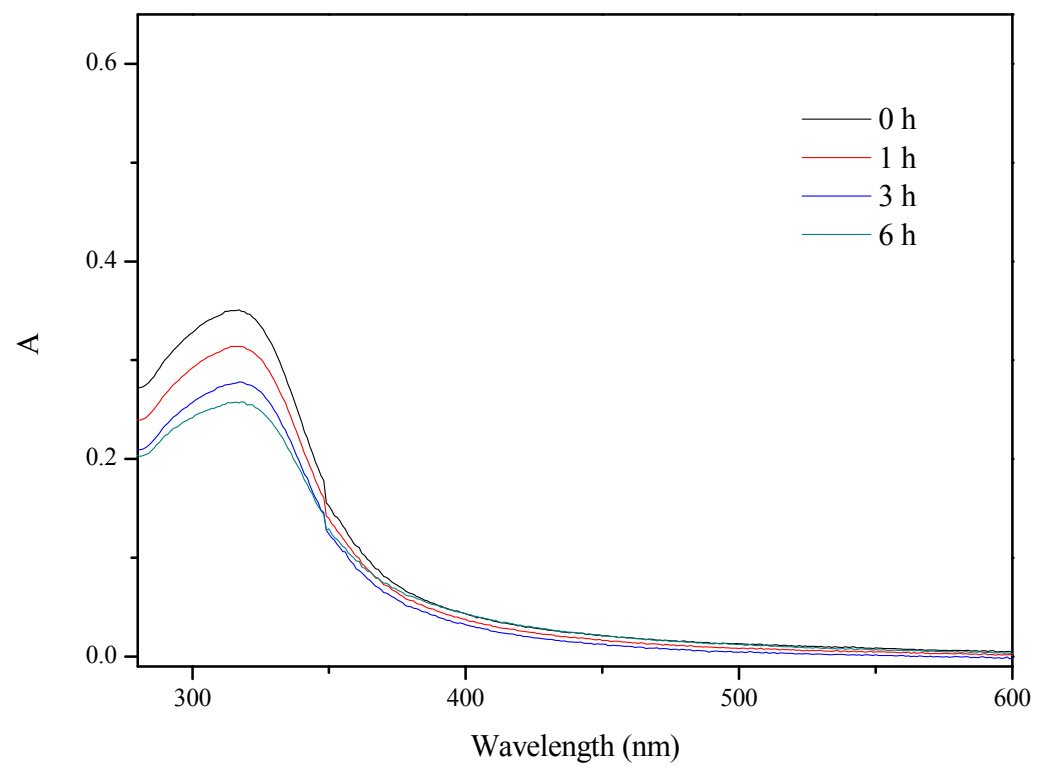

Figure S44. Absorption spectra of a $10^{-5} \mathrm{M}$ aqueous solution (containing 0.1\% DMSO) of $\mathbf{8}$ at different times. 


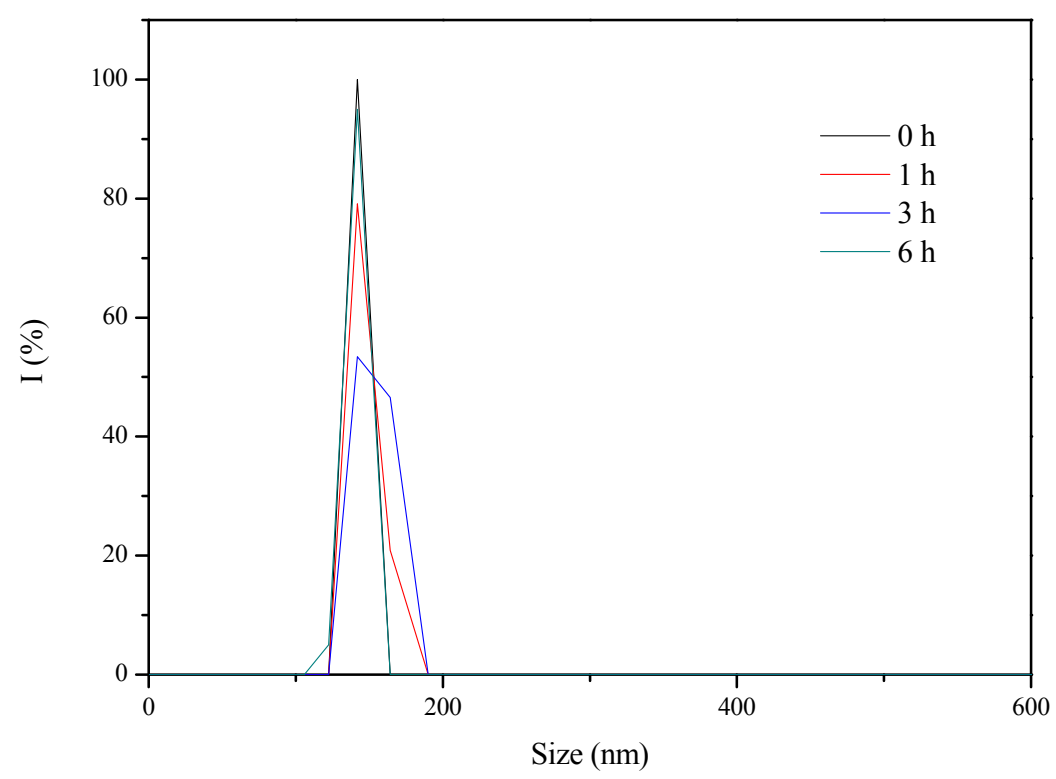

Figure S45. Dynamic light scattering (DLS) spectra of a $10^{-5} \mathrm{M}$ aqueous solution (containing $0.1 \%$ DMSO) of 1 at different times.

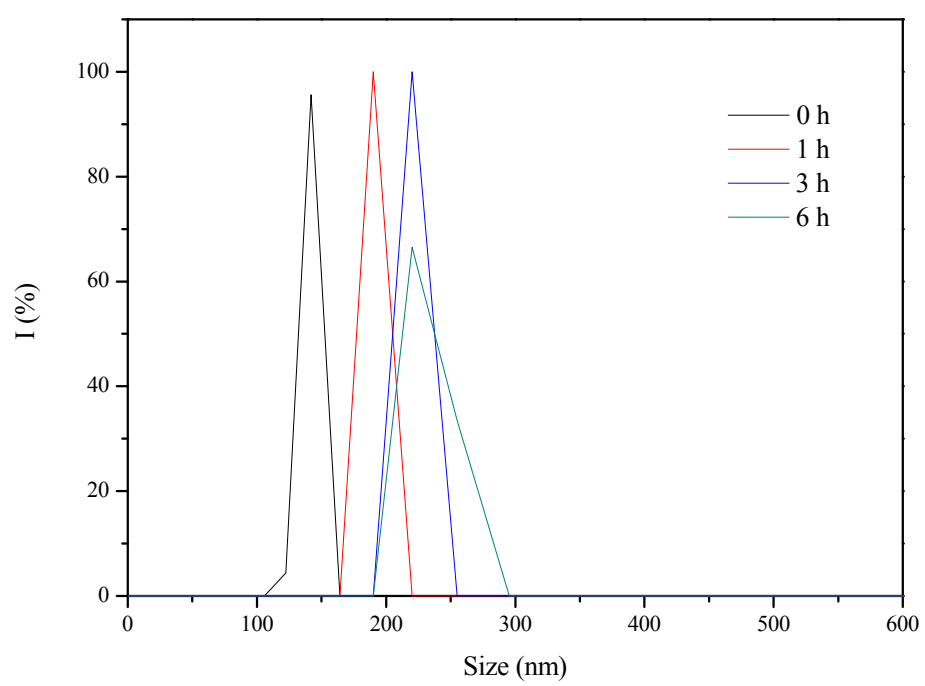

Figure S46. Dynamic light scattering (DLS) spectra of a $10^{-5} \mathrm{M}$ aqueous solution (containing $0.1 \%$ DMSO) of 2 at different times. 


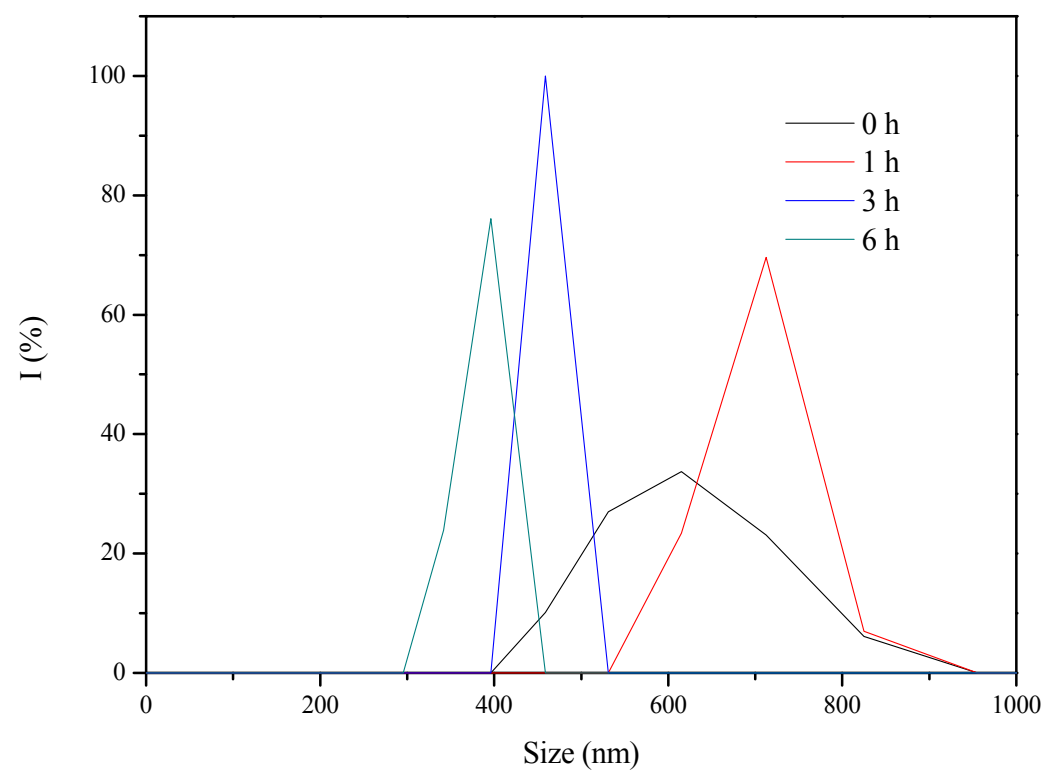

Figure S47. Dynamic light scattering (DLS) spectra of a $10^{-5} \mathrm{M}$ aqueous solution (containing $0.1 \%$ DMSO) of $\mathbf{3}$ at different times.

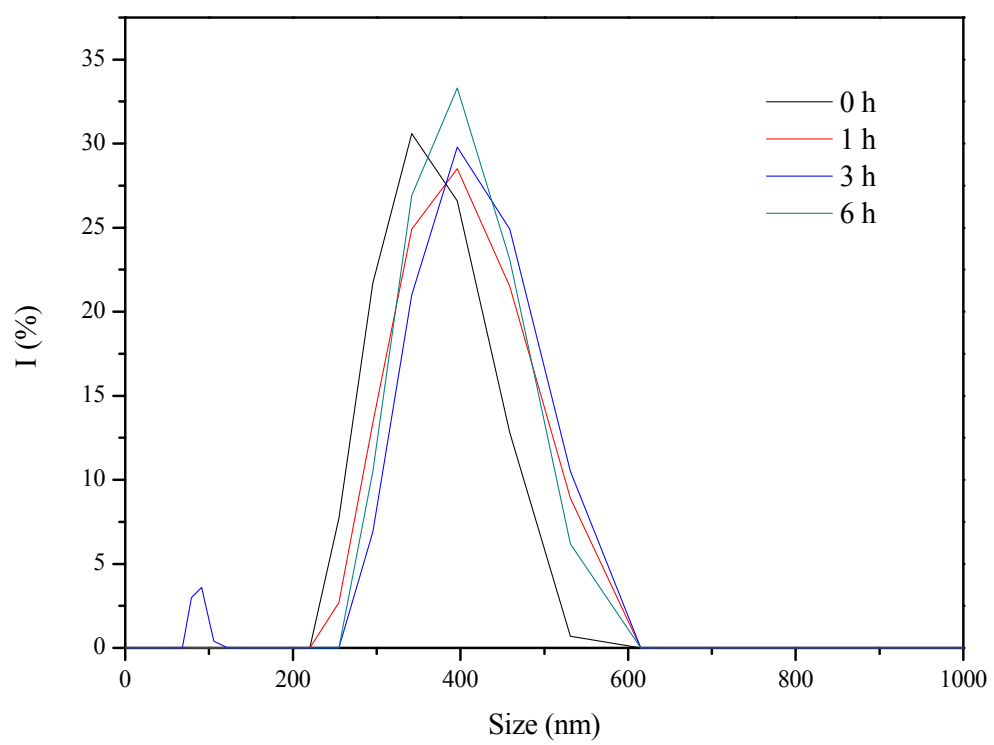

Figure S48. Dynamic light scattering (DLS) spectra of a $10^{-5} \mathrm{M}$ aqueous solution (containing 0.1\% DMSO) of 4 at different times. 


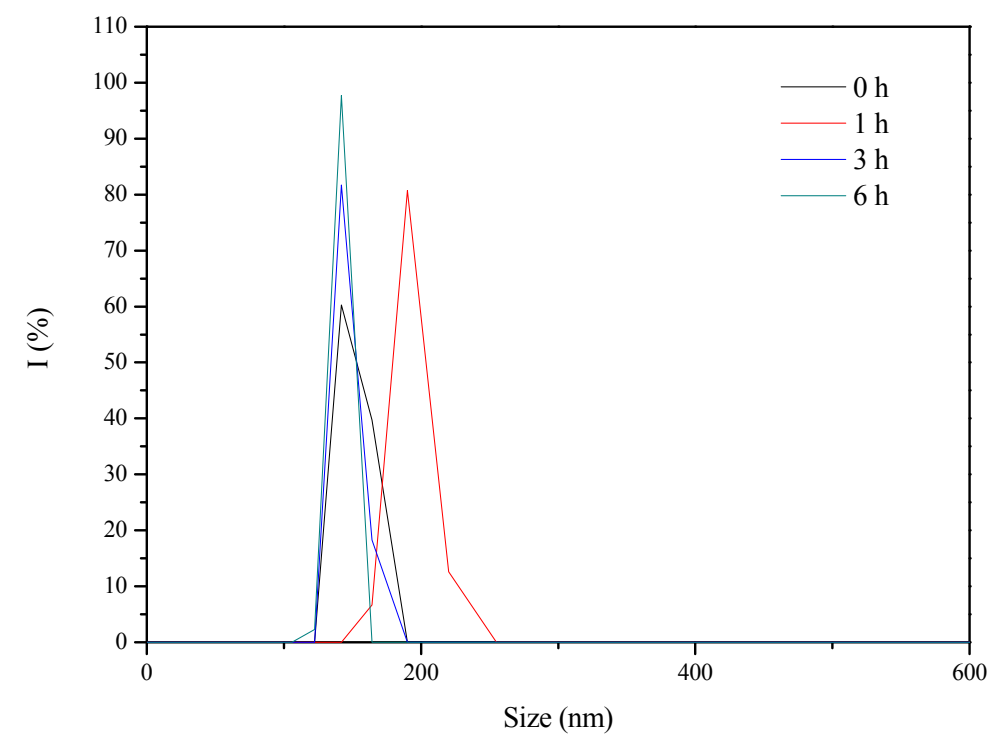

Figure S49. Dynamic light scattering (DLS) spectra of a $10^{-5} \mathrm{M}$ aqueous solution (containing $0.1 \%$ DMSO) of 5 at different times.

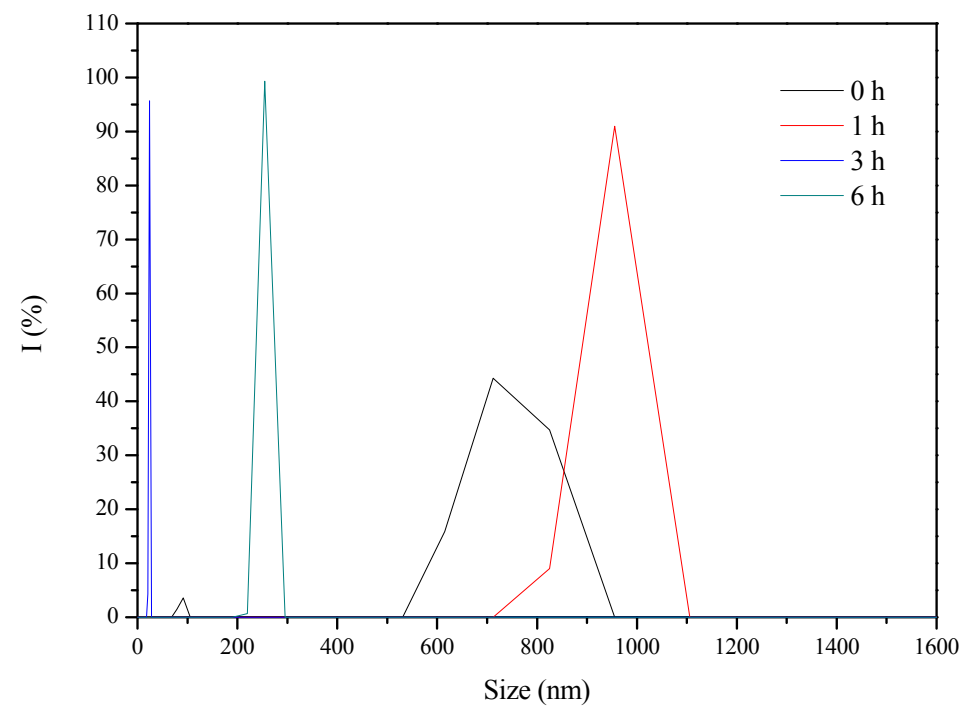

Figure S50. Dynamic light scattering (DLS) spectra of a $10^{-5} \mathrm{M}$ aqueous solution (containing $0.1 \%$ DMSO) of 6 at different times. 


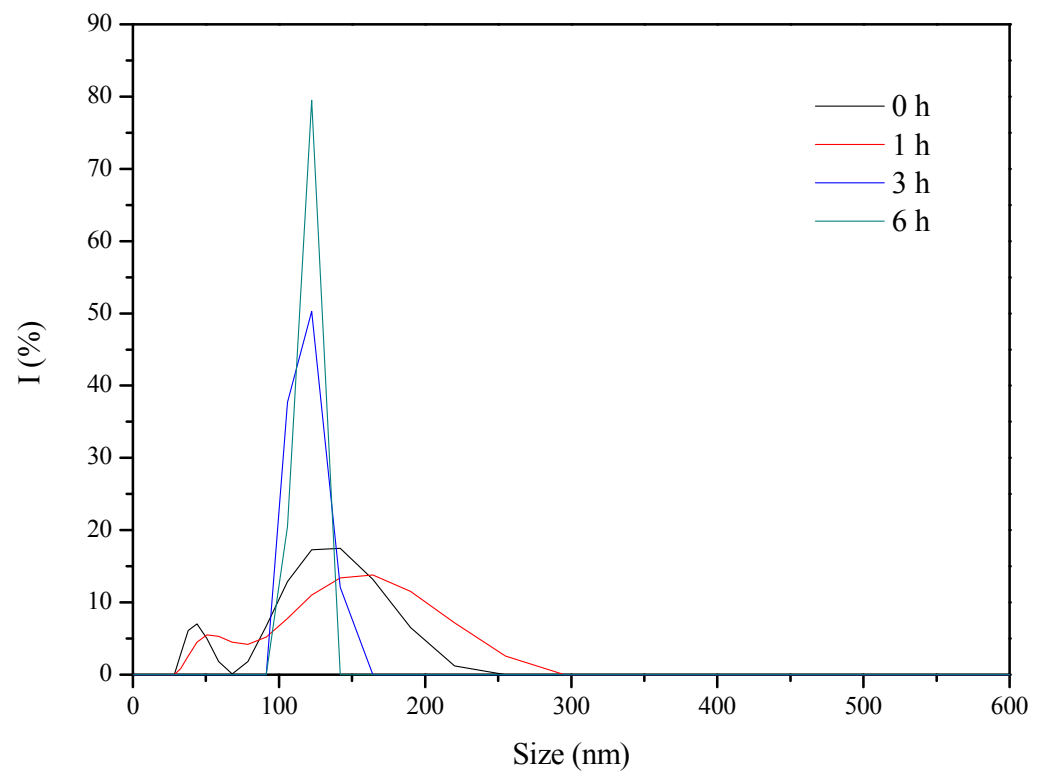

Figure S51. Dynamic light scattering (DLS) spectra of a $10^{-5} \mathrm{M}$ aqueous solution (containing $0.1 \% \mathrm{DMSO}$ ) of 7 at different times.

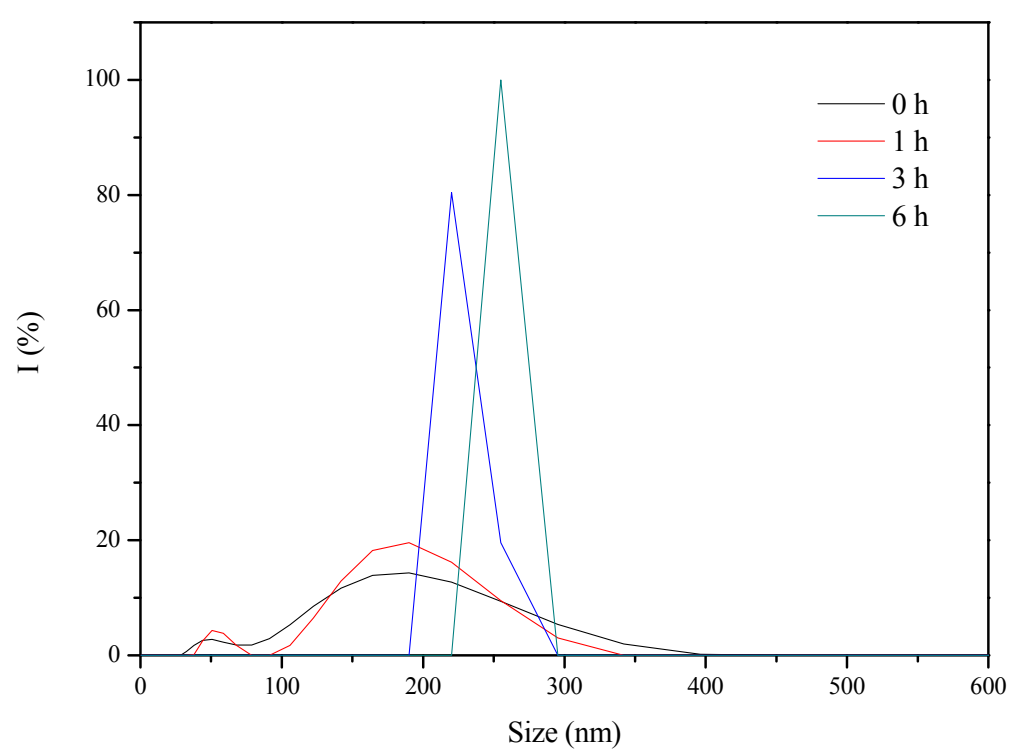

Figure S52. Dynamic light scattering (DLS) spectra of a $10^{-5} \mathrm{M}$ aqueous solution (containing $0.1 \%$ DMSO) of 8 at different times. 


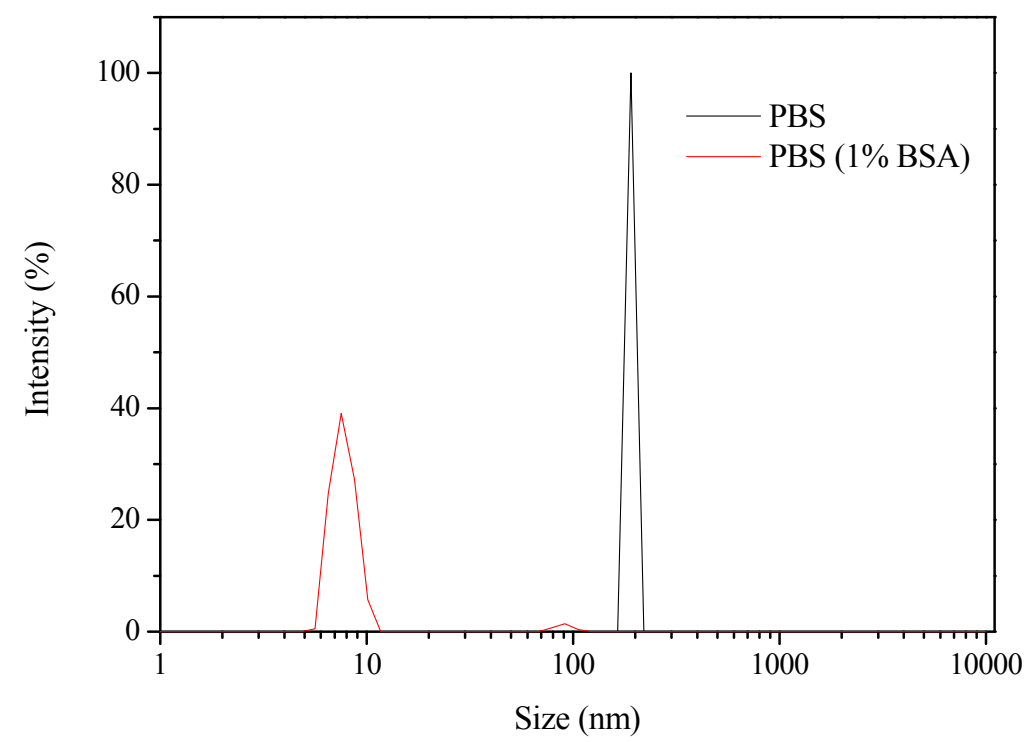

Figure S53. Dynamic light scattering (DLS) spectra of a $10^{-5} \mathrm{M}$ PBS solution of 1 (black line) and in the presence of 1\% BSA protein (red line).

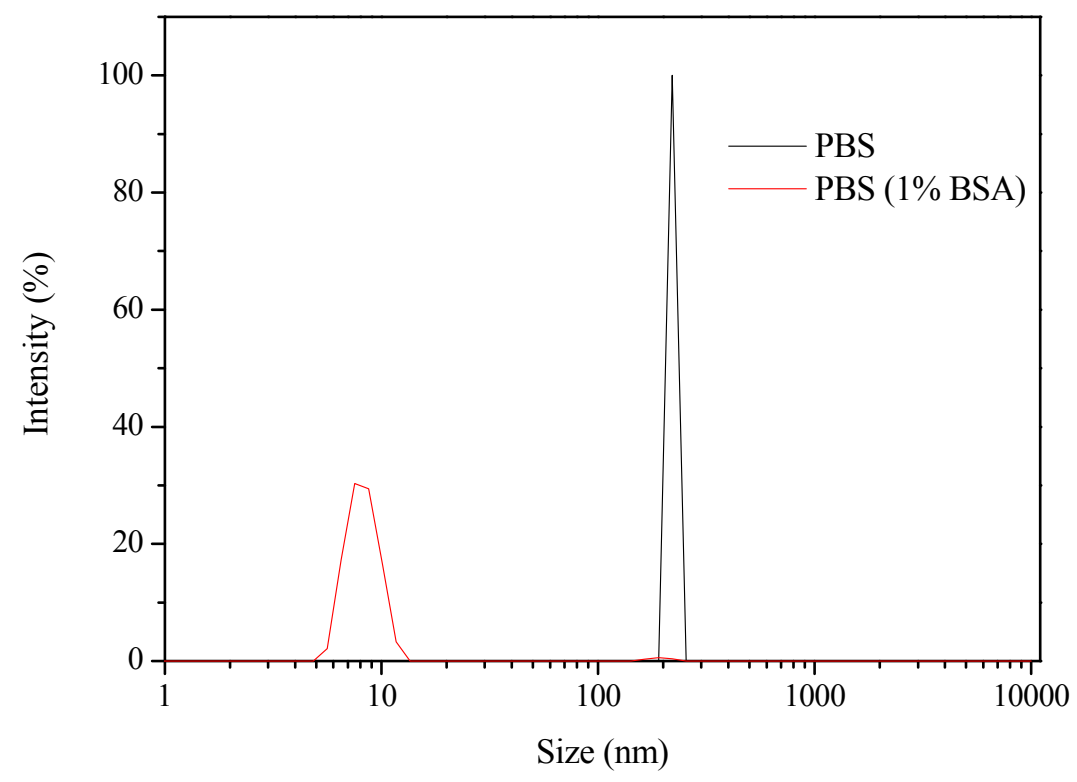

Figure S54. Dynamic light scattering (DLS) spectra of a $10^{-5} \mathrm{M}$ PBS solution of 2 (black line) and in the presence of 1\% BSA protein (red line). 


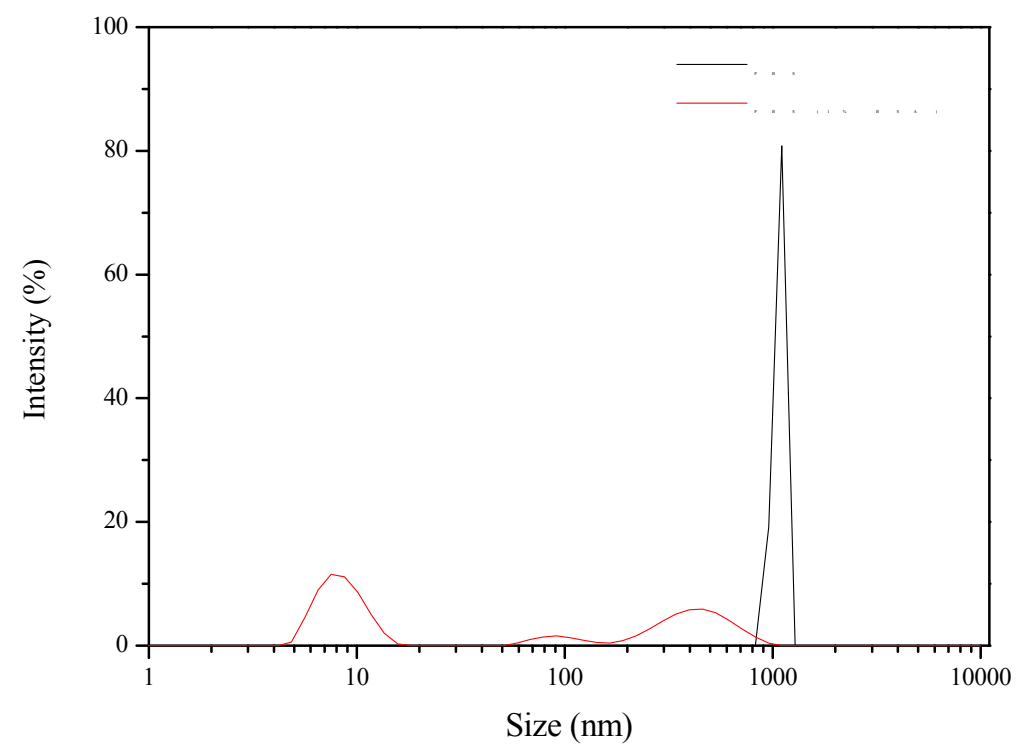

Figure S55. Dynamic light scattering (DLS) spectra of a $10^{-5} \mathrm{M}$ PBS solution of $\mathbf{3}$ (black line) and in the presence of 1\% BSA protein (red line).

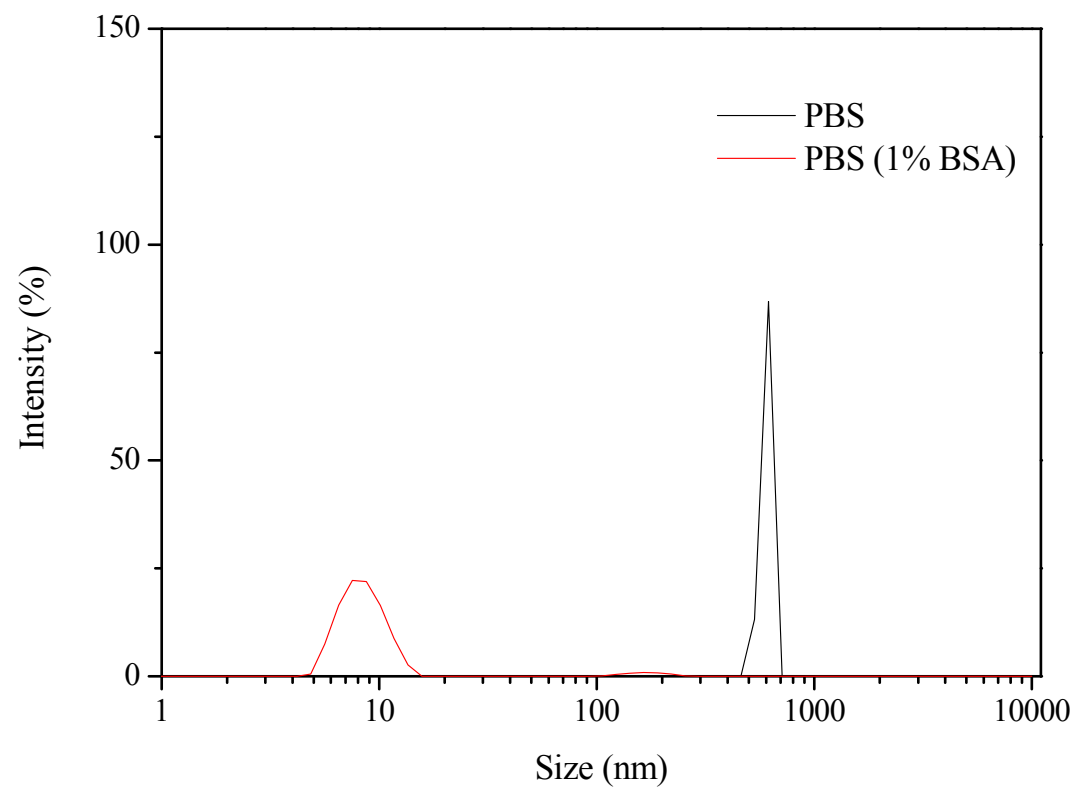

Figure S56. Dynamic light scattering (DLS) spectra of a $10^{-5} \mathrm{M}$ PBS solution of 4 (black line) and in the presence of 1\% BSA protein (red line). 


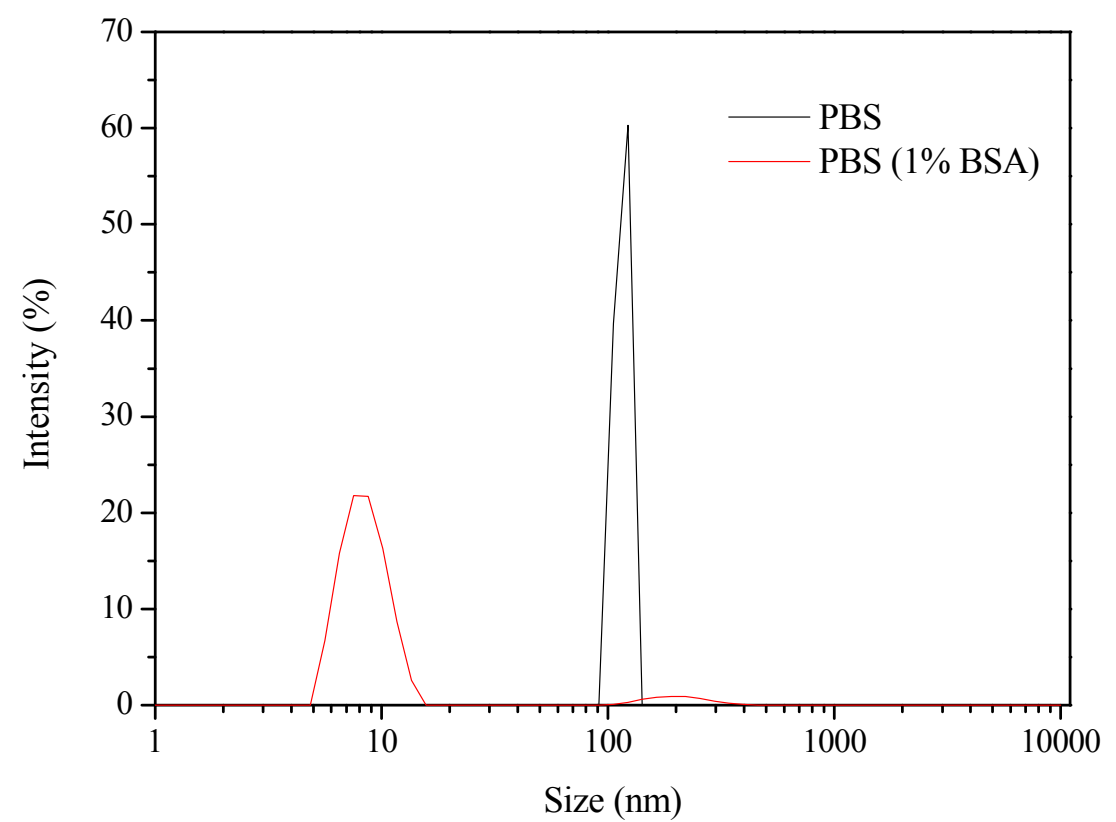

Figure S57. Dynamic light scattering (DLS) spectra of a $10^{-5} \mathrm{M}$ PBS solution of 5 (black line) and in the presence of 1\% BSA protein (red line).

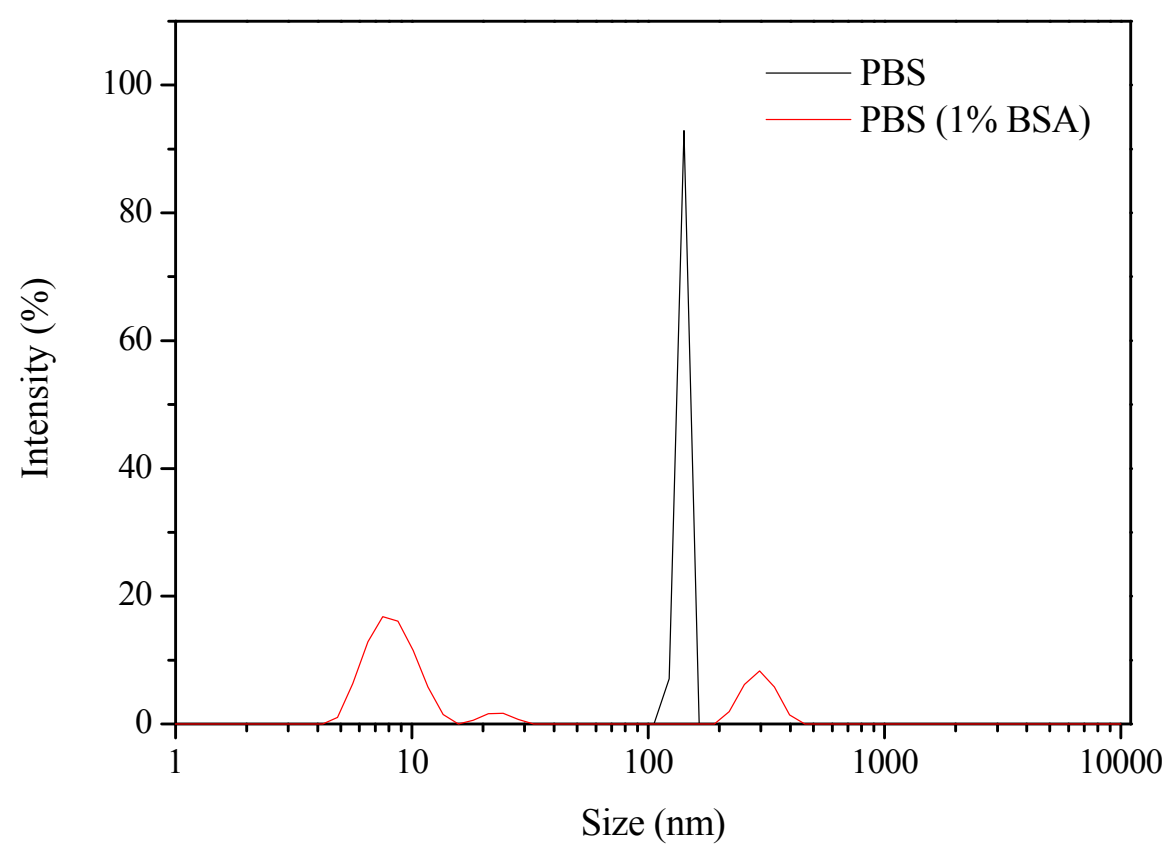

Figure S58. Dynamic light scattering (DLS) spectra of a $10^{-5} \mathrm{M}$ PBS solution of 6 (black line) and in the presence of 1\% BSA protein (red line). 


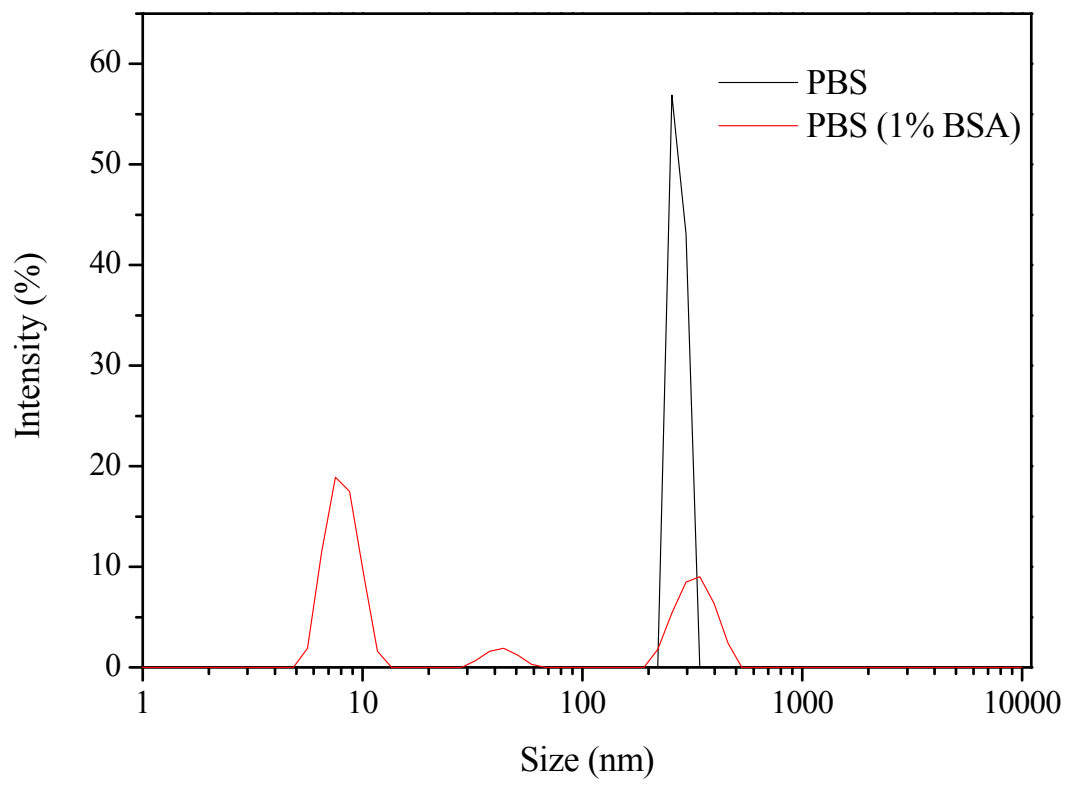

Figure S59. Dynamic light scattering (DLS) spectra of a $10^{-5} \mathrm{M}$ PBS solution of 7 (black line) and in the presence of 1\% BSA protein (red line).

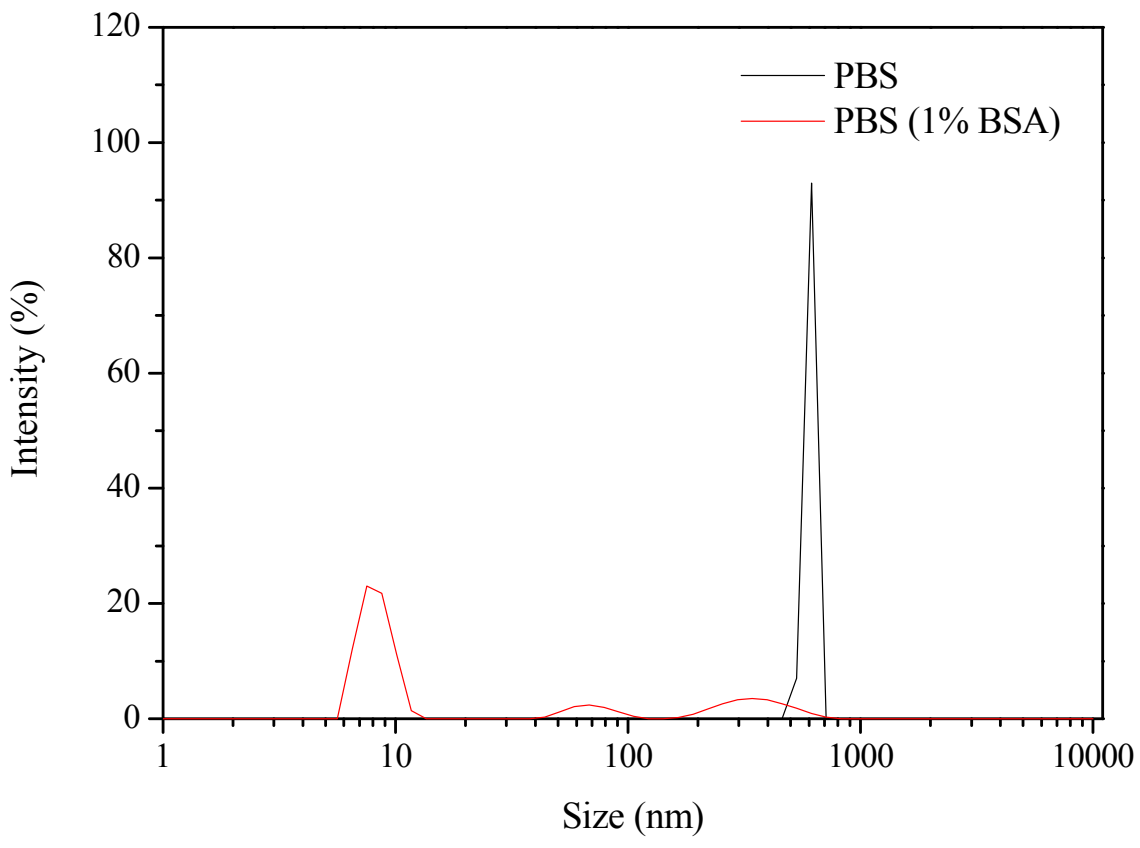

Figure S60. Dynamic light scattering (DLS) spectra of a $10^{-5} \mathrm{M}$ PBS solution of 8 (black line) and in the presence of 1\% BSA protein (red line). 


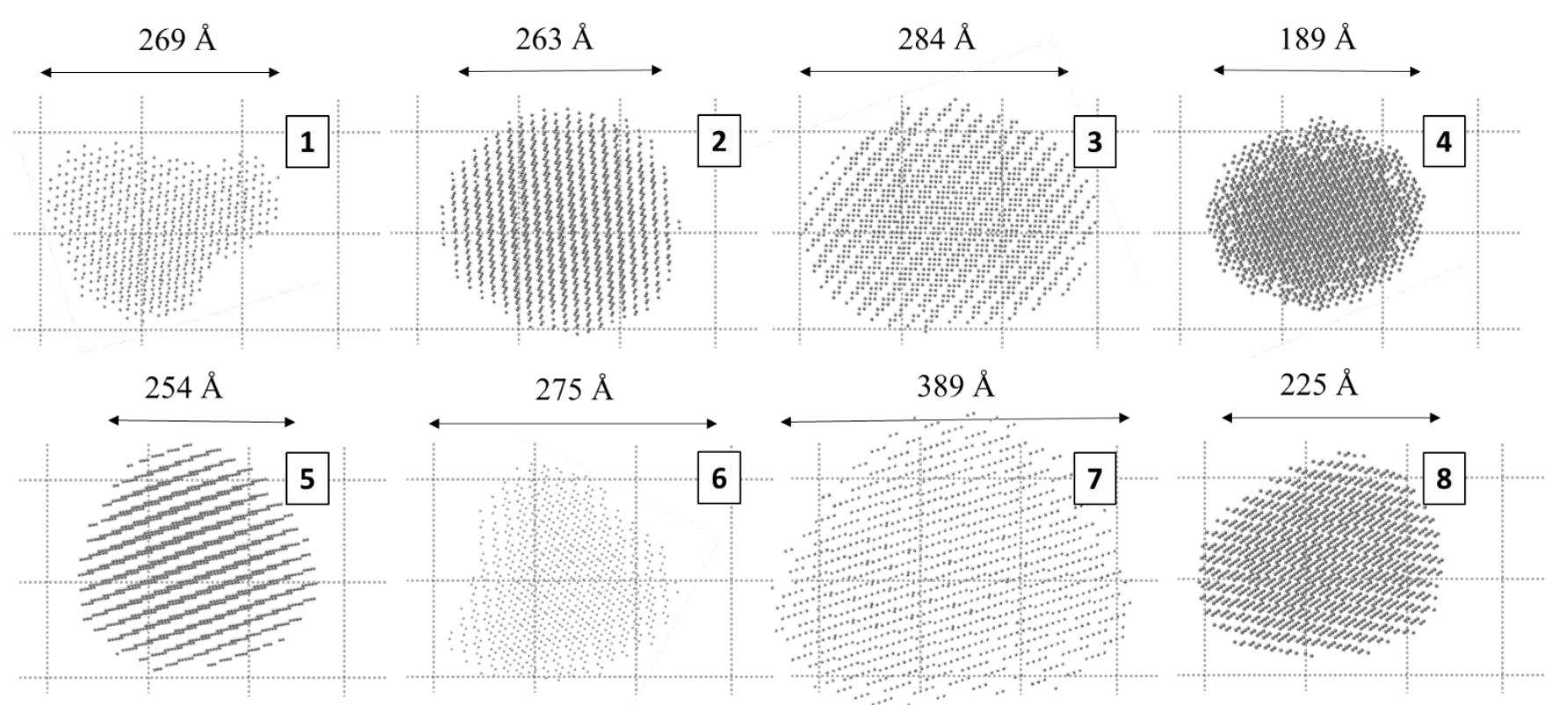

Figure S61. DAMMIN Representation of the aggregates' size and shape recorded in solutions with analogous conditions than those considered for the biological assays.

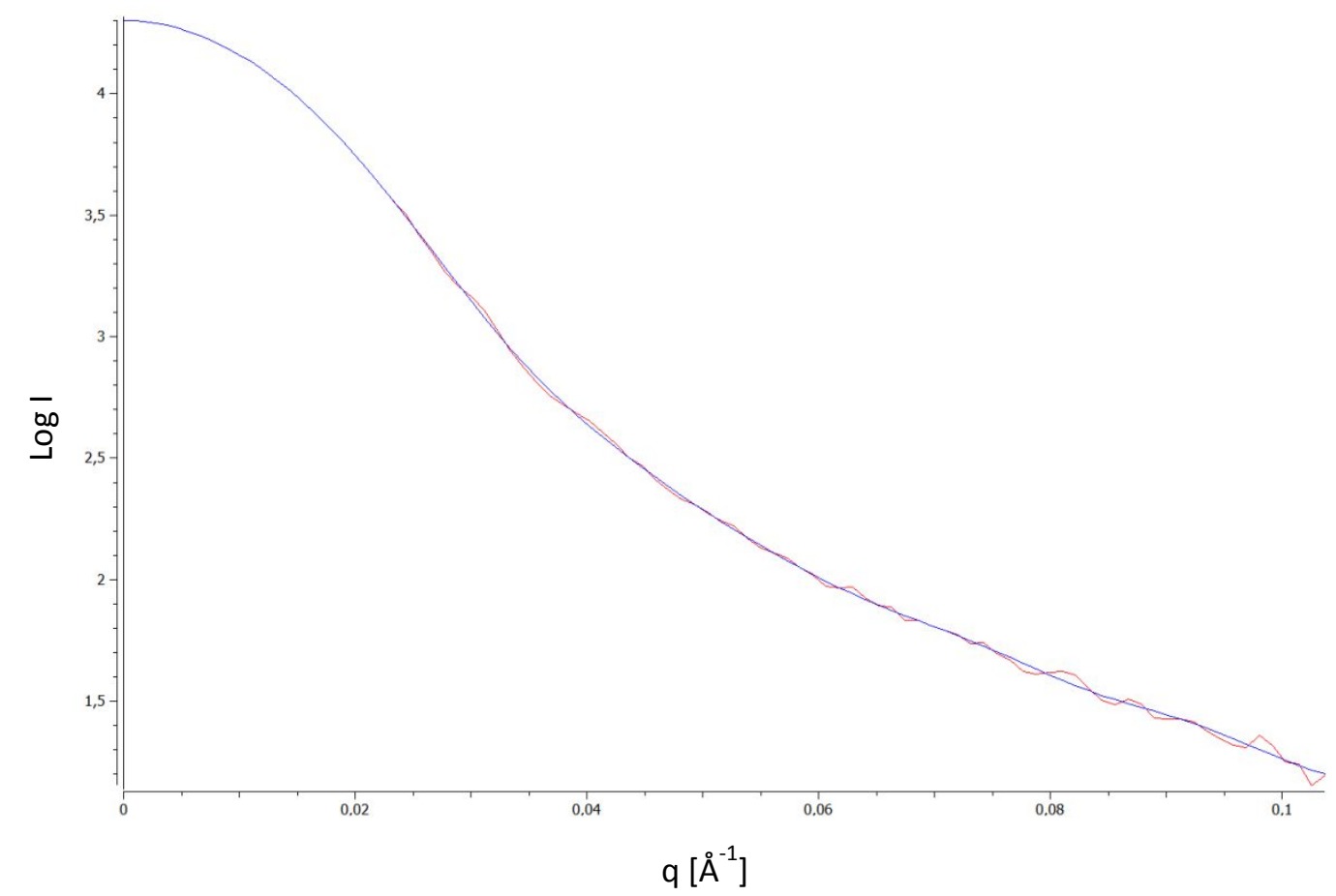

Figure S62. Experimental scattering curve of 1 (red) measured in water at $10^{-5} \mathrm{M}$ and theoretical fitting (blue) by using the program GNOM. 


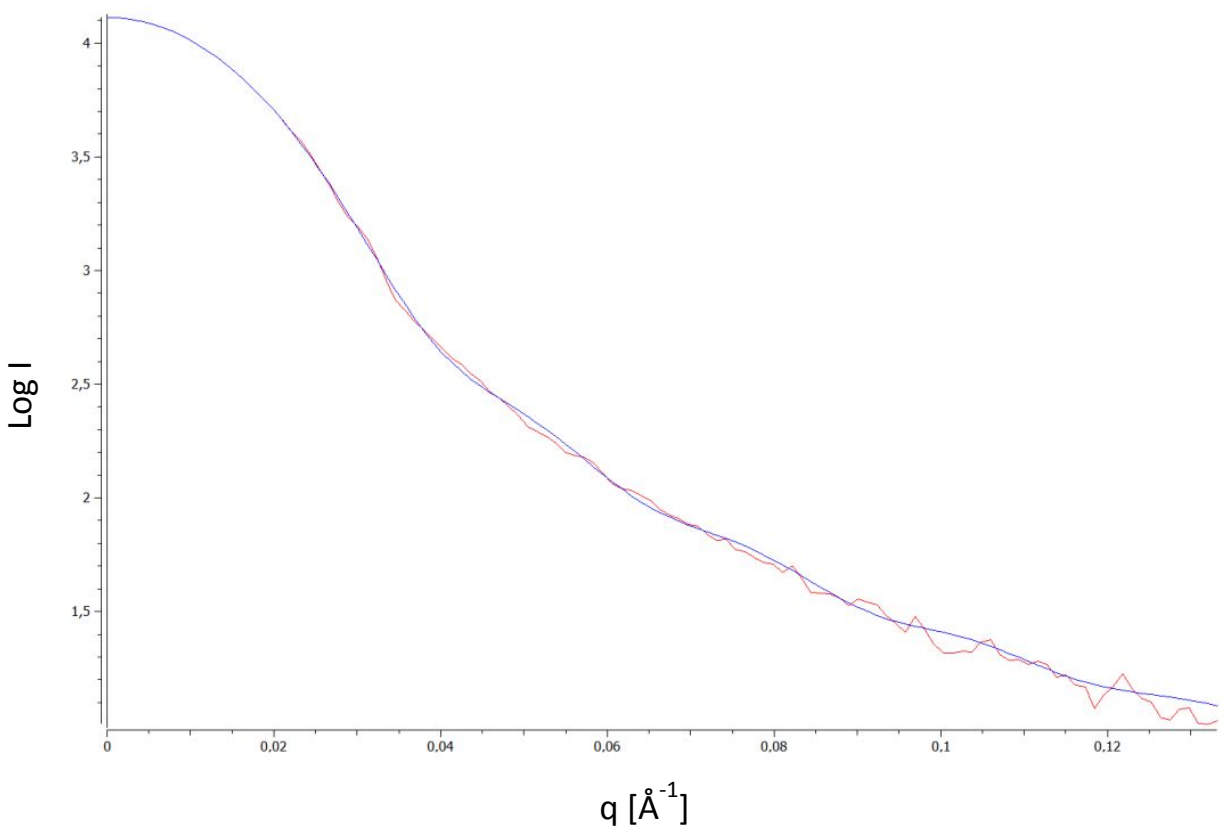

Figure S63. Experimental scattering curve of 2 (red) measured in water at $10^{-5} \mathrm{M}$ and theoretical fitting (blue) by using the program GNOM.

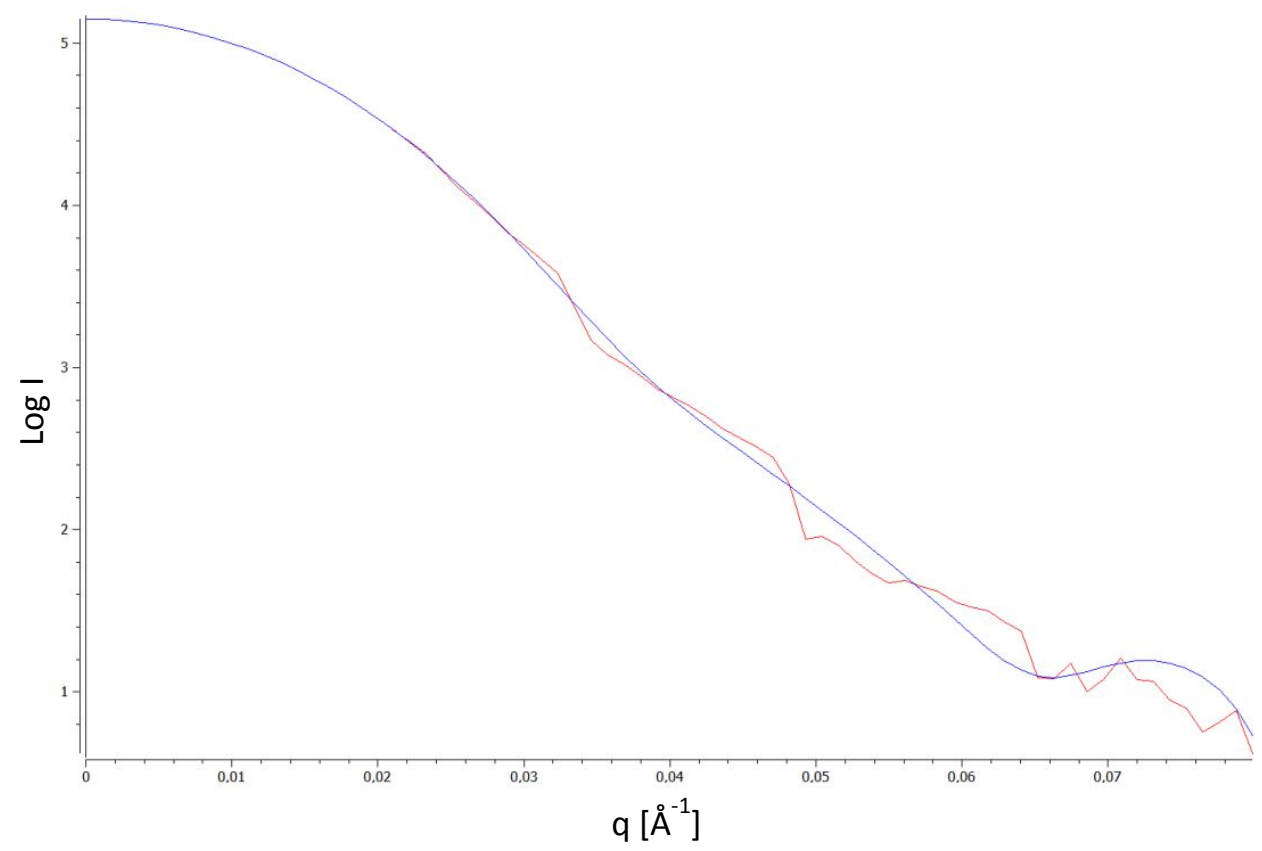

Figure S64. Experimental scattering curve of 3 (red) measured in water/tetrahydrofuran mixtures (50:50) at $10^{-5} \mathrm{M}$ and theoretical fitting (blue) by using the program GNOM. 


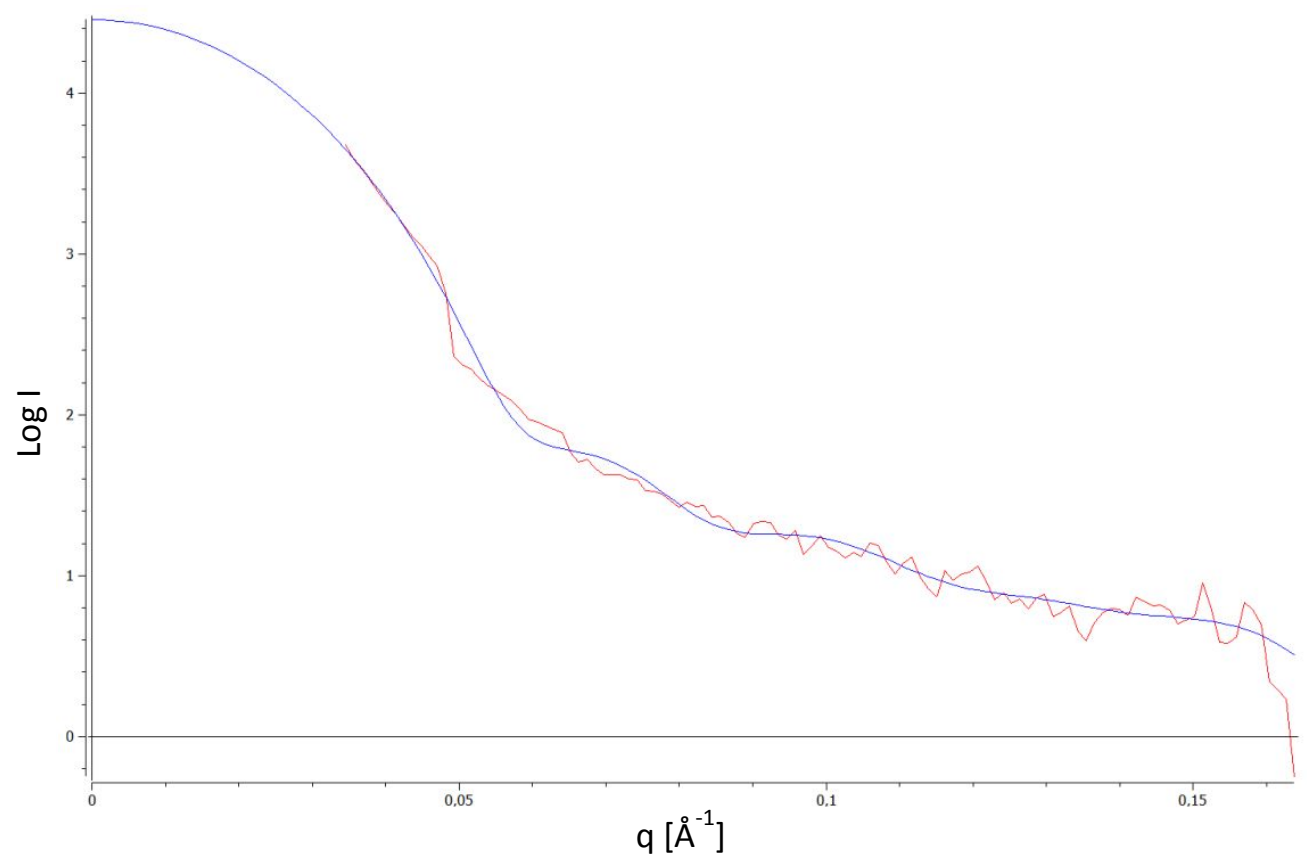

Figure S65. Experimental scattering curve of $\mathbf{4}$ (red) measured in water/tetrahydrofuran mixtures (50:50) at $10^{-5} \mathrm{M}$ and theoretical fitting (blue) by using the program GNOM.

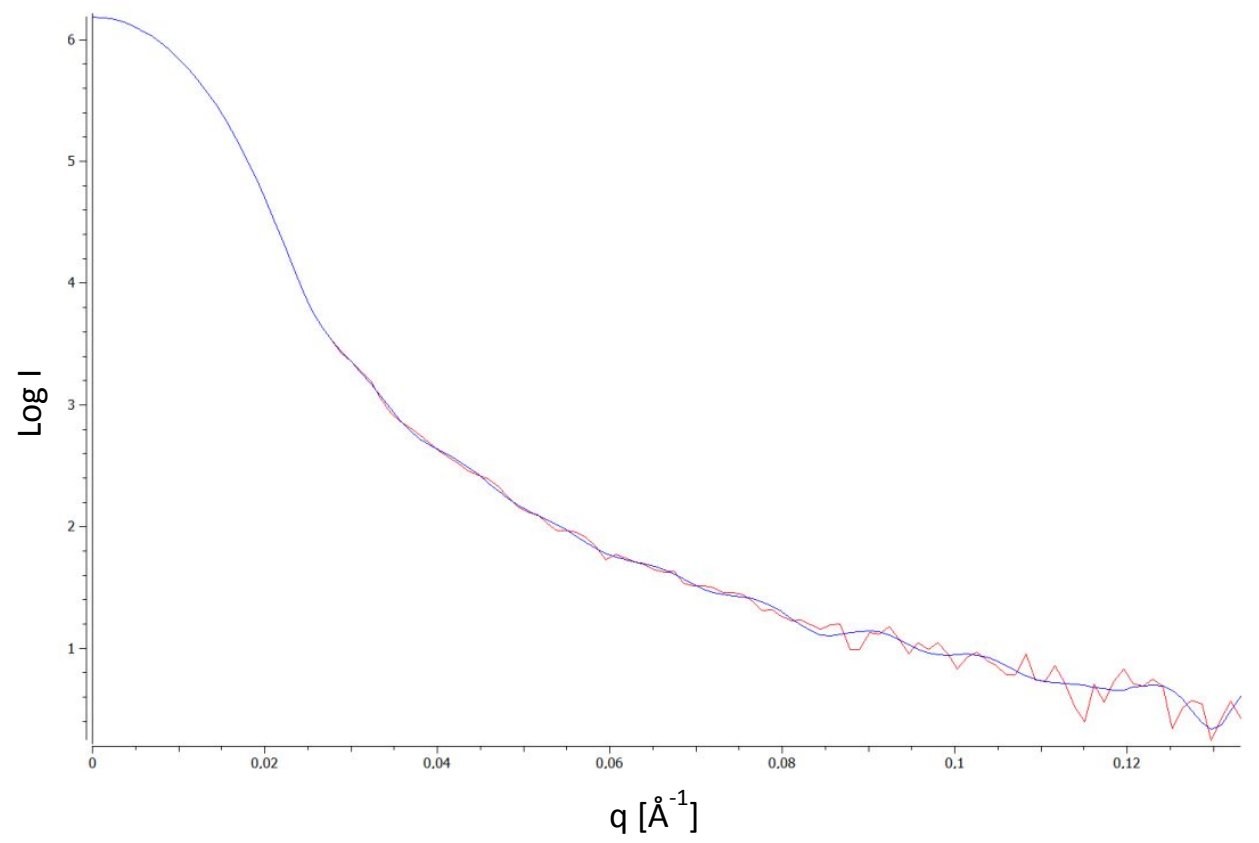

Figure S66. Experimental scattering curve of 5 (red) measured in water/tetrahydrofuran mixtures (50:50) at $10^{-5} \mathrm{M}$ and theoretical fitting (blue) by using the program GNOM. 


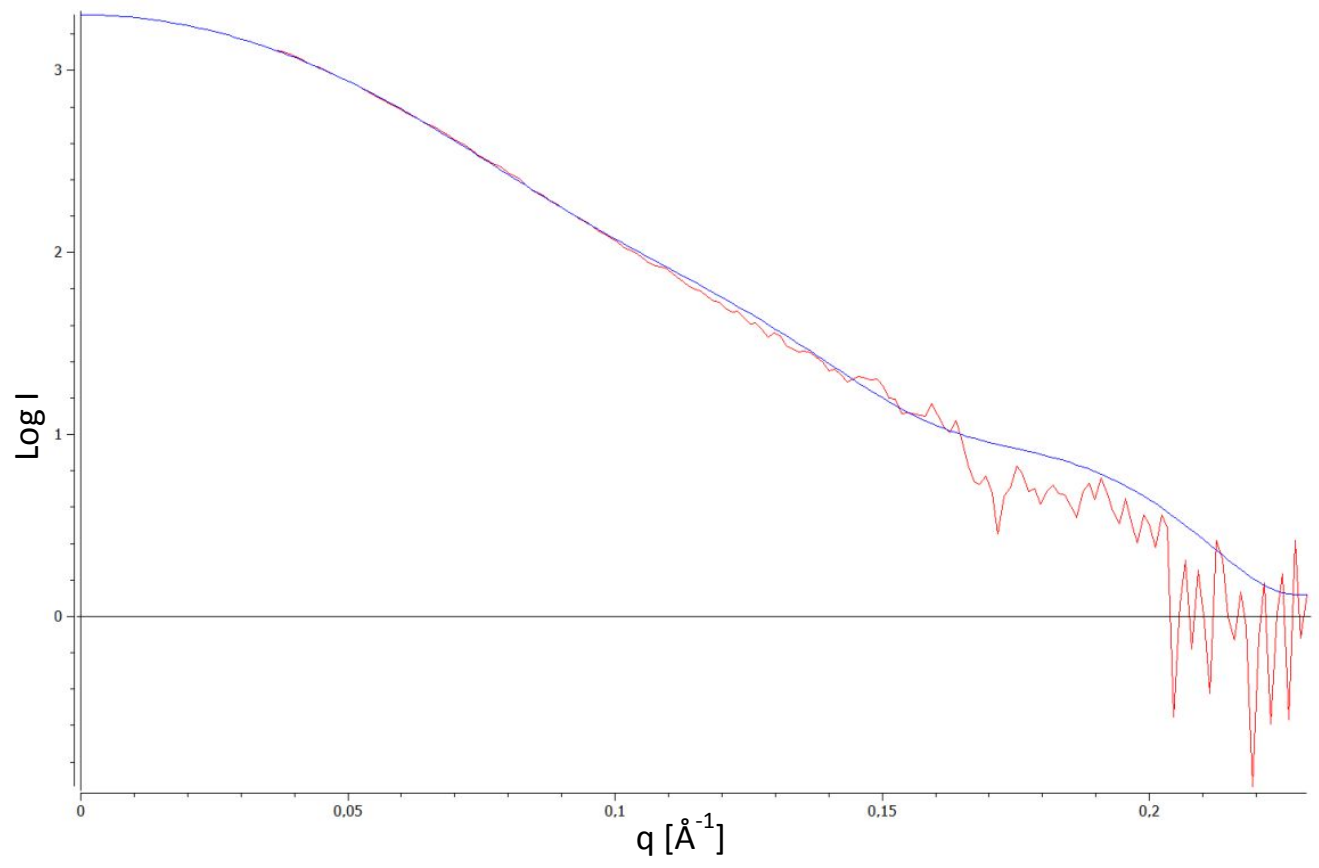

Figure S67. Experimental scattering curve of 6 (red) measured in water/tetrahydrofuran mixtures (50:50) at $10^{-5} \mathrm{M}$ and theoretical fitting (blue) by using the program GNOM.

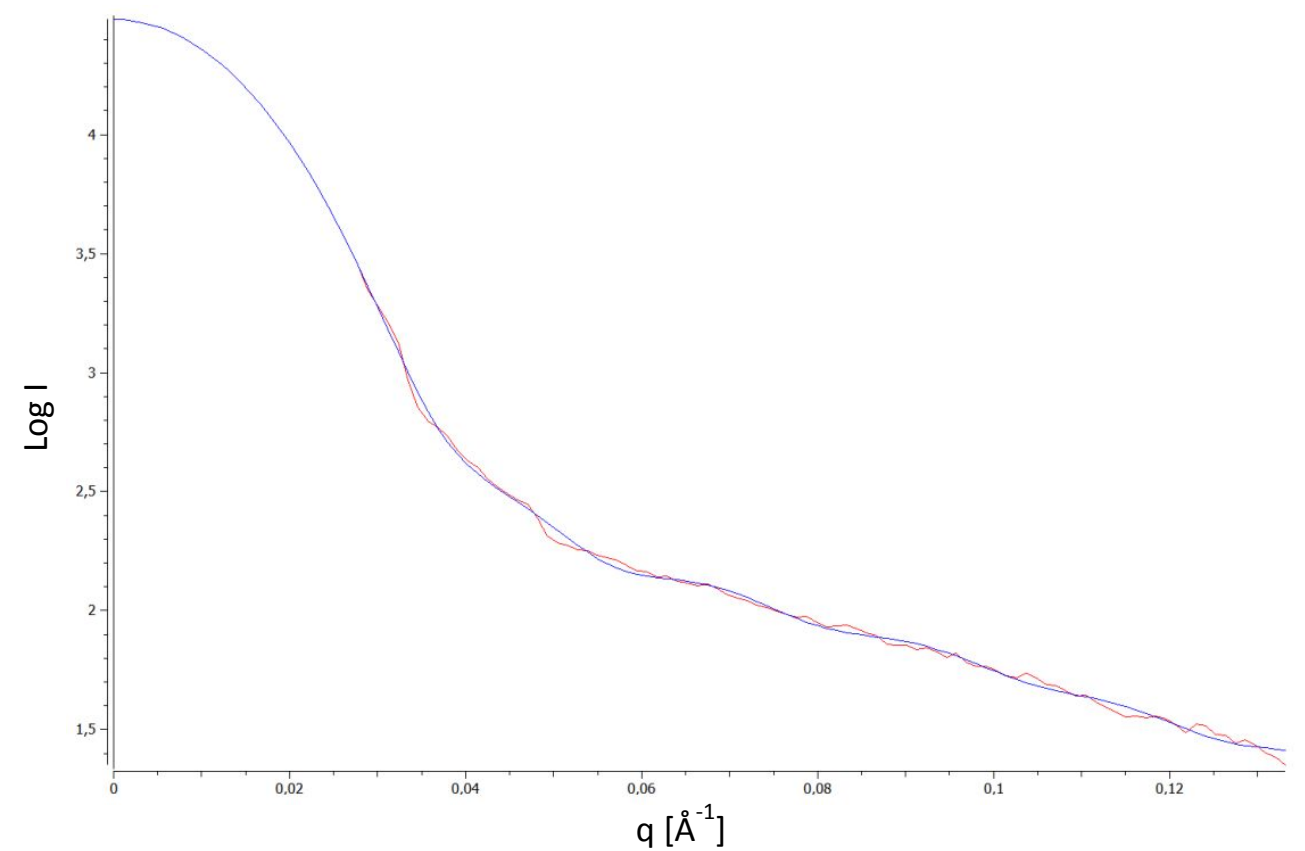

Figure S68. Experimental scattering curve of 7 (red) measured in water/tetrahydrofuran mixtures (50:50) at $10^{-5} \mathrm{M}$ and theoretical fitting (blue) by using the program GNOM. 


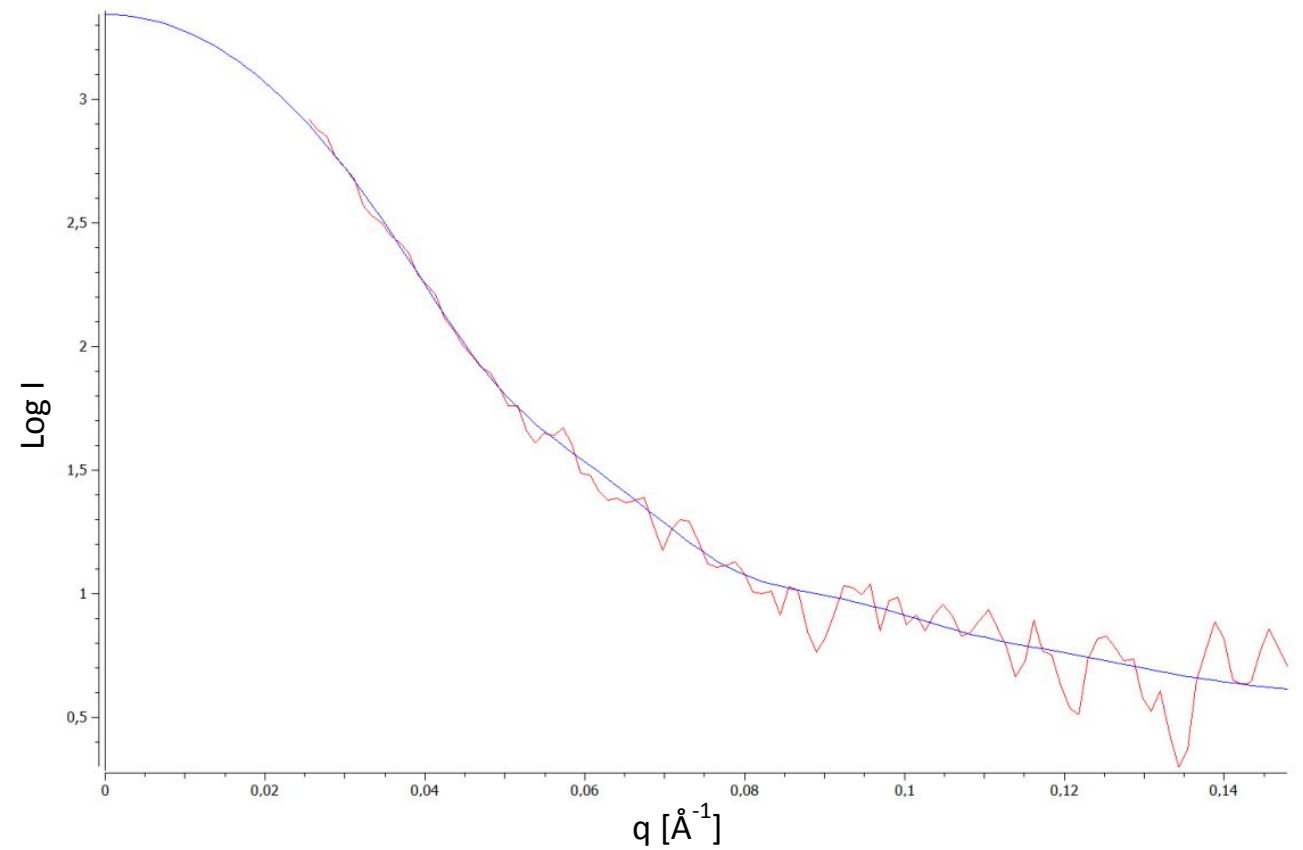

Figure S69. Experimental scattering curve of 8 (red) measured in water/tetrahydrofuran mixtures (50:50) at $10^{-5} \mathrm{M}$ and theoretical fitting (blue) by using the program GNOM.

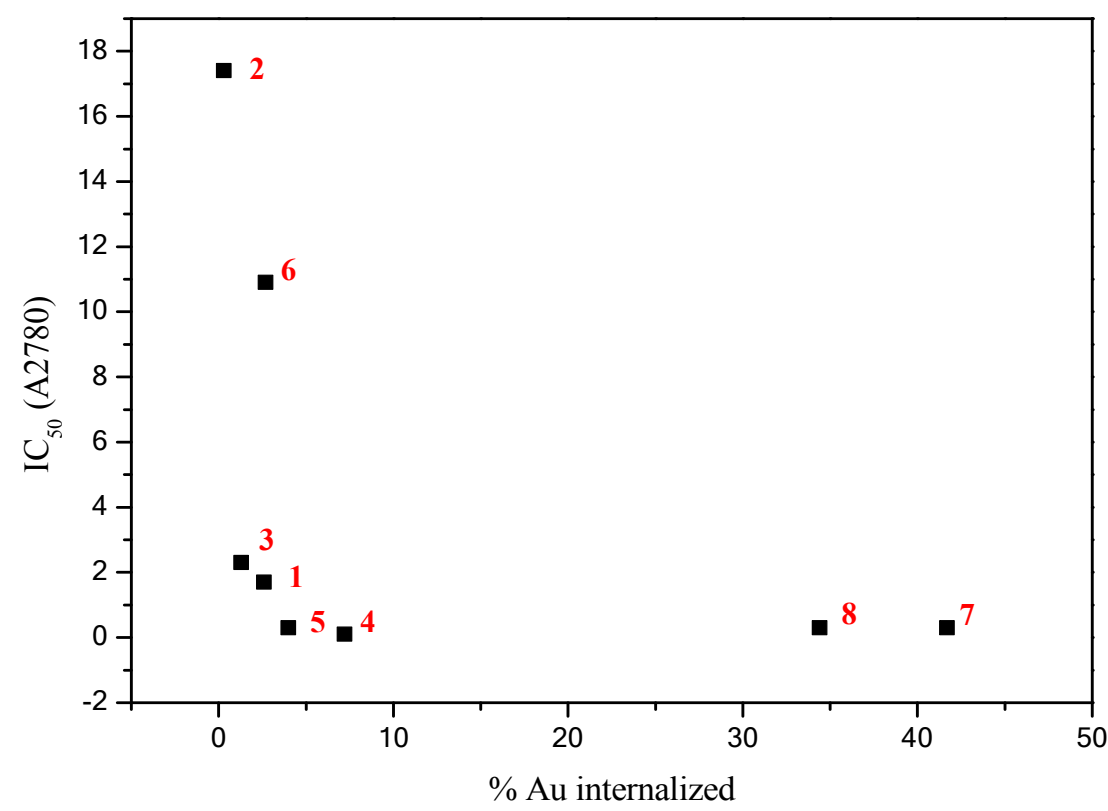

Figure S70. Plot representing \% Au internalized vs $\mathrm{IC}_{50}$ values against $\mathrm{A} 2780$ cell line. 


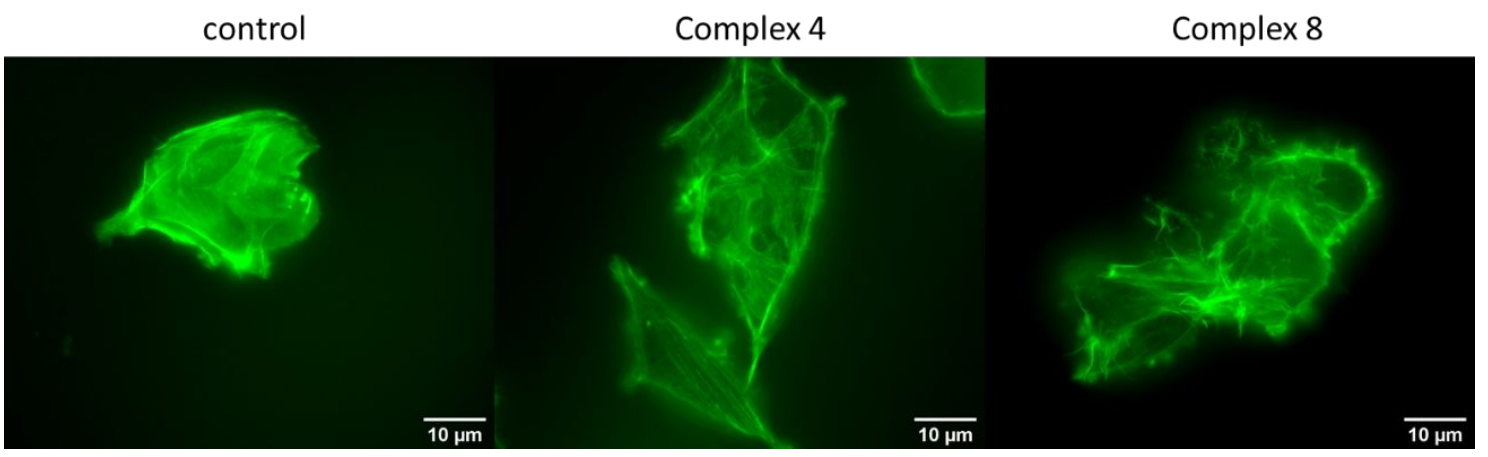

Figure S71. Interaction of complexes 4 and 8 with actin. Ovarian cancer cell line A2780 was incubated for $3 \mathrm{~h}$ with the $\mathrm{IC}_{50}$ of each complex $(0.1 \mu \mathrm{M}$ for complex 4 and $0.3 \mu \mathrm{M}$ for complex 8) or $0.1 \%(\mathrm{v} / \mathrm{v}) \mathrm{DMSO}$ for control purposes, and then fixed with formaldehyde 4\% (w/v). Cells were stained with AlexaFluor 488 phalloidin (Invitrogen) and images were acquired in a Ti-U Eclipse inverted microscope with green filter cube (excitation filter range $465-495 \mathrm{~nm}$ and emission filter range at $515-555 \mathrm{~nm}$ ). 
Table S1. Crystal data and structure for $\mathbf{1 a}, \mathbf{1 b}, \mathbf{4}$, and 5.

\begin{tabular}{|c|c|c|c|c|}
\hline Compound & $1 \mathbf{a}$ & $\mathbf{1 b}$ & 4 & 5 \\
\hline Formula & $\begin{array}{l}3\left(\mathrm{C}_{14} \mathrm{H}_{18} \mathrm{AuN}_{4} \mathrm{P}\right) \\
\mathrm{CH}_{2} \mathrm{Cl}_{2}\end{array}$ & $\mathrm{C}_{14} \mathrm{H}_{18} \mathrm{Au} \mathrm{N} \mathrm{N}_{4} \mathrm{P}$ & $\begin{array}{l}\mathrm{C}_{26} \mathrm{H}_{21} \mathrm{AuNP} \\
\mathrm{CH}_{2} \mathrm{Cl}_{2}\end{array}$ & $\mathrm{C}_{14} \mathrm{H}_{21} \mathrm{AuNP}$ \\
\hline Crystal size (mm) & $0.44 \times 0.04 \times 0.04$ & $0.44 \times 0.07 \times 0.02$ & $\begin{array}{l}0.42 \times 0.32 \times \\
0.14\end{array}$ & $\begin{array}{l}0.13 \times 0.08 \times \\
0.07\end{array}$ \\
\hline Mw & 1495.70 & 470.26 & 660.30 & 431.25 \\
\hline Temp. (K) & $170(1)$ & $170(1)$ & $170(1)$ & $120.0(1)$ \\
\hline Wavelength $(\AA)$ & 0.71073 & 0.71073 & 0.71073 & 1.54184 \\
\hline Crystal system & Orthorhombic & Orthorhombic & Monoclinic & Monoclinic \\
\hline Space group & $\operatorname{Pna}_{1}$ & $F d d 2$ & $P 2_{1} / n$ & $P 2_{1} / n$ \\
\hline $\mathrm{a}(\AA)$ & $23.3244(3)$ & $21.9640(7)$ & $17.7242(3)$ & $7.18100(18)$ \\
\hline $\mathrm{b}(\AA)$ & $9.2765(1)$ & $41.1815(11)$ & $14.0652(3)$ & $19.7054(6)$ \\
\hline c $(\AA)$ & $45.0709(7)$ & $6.4250(2)$ & $20.1117(3)$ & $10.4601(3)$ \\
\hline$\alpha\left(^{\circ}\right)$ & 90 & 90 & 90 & 90 \\
\hline$\beta\left({ }^{\circ}\right)$ & 90 & 90 & $93.153(1)$ & $96.565(2)$ \\
\hline$\gamma\left({ }^{\circ}\right)$ & 90 & 90 & 90 & 90 \\
\hline Volume $\left(\AA^{3}\right)$ & $9751.9(2)$ & $5811.5(3)$ & $5006.15(16)$ & $1470.45(7)$ \\
\hline Z & 8 & 16 & 8 & 4 \\
\hline $\mathrm{D}_{\text {calc }}\left(\mathrm{mg} \mathrm{m}^{-3}\right)$ & 2.037 & 2.150 & 1.752 & 1.948 \\
\hline Abs. coef. $\left(\mathrm{mm}^{-1}\right)$ & 9.26 & 10.23 & 6.17 & 19.65 \\
\hline $\mathrm{F}(000)$ & 5712 & 3584 & 2560 & 824 \\
\hline$\theta$ range for data coll. $\left({ }^{\circ}\right)$ & 1.8 to 26.4 & 2.7 to 31.4 & 1.8 to 31.4 & 4.8 to 72.8 \\
\hline Reflns coll./independent & $77281 / 19153$ & $15857 / 4324$ & $57127 / 16247$ & $4464 / 2586$ \\
\hline Data /parameters/restraints & $19153 / 1130 / 768$ & $4324 / 182 / 1$ & $16247 / 618 / 51$ & $2586 / 157 / 0$ \\
\hline $\mathrm{S}$ & 1.08 & 1.02 & 1.04 & 1.10 \\
\hline Final R index $(I>2 \sigma(I))$ & $\begin{array}{l}\mathrm{R} 1=0.067 \\
w \mathrm{R} 2=0.153\end{array}$ & $\begin{array}{l}\mathrm{R} 1=0.049 \\
w \mathrm{R} 2=0.096\end{array}$ & $\begin{array}{l}\mathrm{R} 1=0.052 \\
w \mathrm{R} 2=0.088\end{array}$ & $\begin{array}{l}\mathrm{R} 1=0.024 \\
w \mathrm{R} 2=0.063\end{array}$ \\
\hline $\mathrm{R}$ index (all data) & $\begin{array}{l}\mathrm{R} 1=0.107 \\
w \mathrm{R} 2=0.175\end{array}$ & $\begin{array}{l}\mathrm{R} 1=0.072 \\
w \mathrm{R} 2=0.106\end{array}$ & $\begin{array}{l}\mathrm{R} 1=0.098 \\
w \mathrm{R} 2=0.100\end{array}$ & $\begin{array}{l}\mathrm{R} 1=0.025 \\
w \mathrm{R} 2=0.064\end{array}$ \\
\hline Peak and hole (e $\left.\AA^{-3}\right)$ & 1.66 and -2.08 & 2.73 and -1.32 & 0.97 and -1.09 & 1.09 and -0.88 \\
\hline CCDC & 2070637 & 2070638 & 2070639 & 2070640 \\
\hline
\end{tabular}


Table S2. Internalization of complexes 4, 5, 7 and $\mathbf{8}$ in ovarian cancer cells A2780 after $3 \mathrm{~h}$ at $37^{\circ} \mathrm{C}$ and $4^{\circ} \mathrm{C}$ and after $6 \mathrm{~h}$ at $37^{\circ} \mathrm{C}$.

\begin{tabular}{|c|c|c|c|c|}
\hline Compound & $\mathbf{4}$ & $\mathbf{5}$ & $\mathbf{7}$ & $\mathbf{8}$ \\
\hline $\mathbf{3 h ~} \mathbf{3 7}^{\mathbf{}} \mathbf{C}$ & $7.2 \%$ & $3.9 \%$ & $41.7 \%$ & $34 \%$ \\
\hline $\mathbf{3 h ~} \mathbf{4}^{\mathbf{0}} \mathbf{C}$ & $4.1 \%$ & $0.38 \%$ & $31.9 \%$ & $23.7 \%$ \\
\hline $\mathbf{6 h ~} \mathbf{3 7} 7^{\mathbf{C}} \mathbf{C}$ & $1.1 \%$ & $1.1 \%$ & $5.2 \%$ & $14.4 \%$ \\
\hline
\end{tabular}

